\title{
LA IGLESIA ALTOMEDIEVAL DE SAN JUAN BAUTISTA EN BAÑOS DE CERRATO (PALENCIA) ${ }^{1}$
}

\author{
POR \\ LUIS CABALLERO ZOREDA y SANTIAGO FEIJOO MARTÍNEZ \\ CEH. CSIC. Madrid
}

\section{RESUMEN}

Análisis arqueológico de la iglesia de San Juan de Baños (Palencia), que se considera construida por orden de Recesvinto en 652 ó 661 de acuerdo con la inscripción que conserva. Se presenta una nueva documentación planimétrica y la ordenación estratigráfica y diacrónica de los restos pertenecientes al edificio primitivo y a las sucesivas restauraciones históricas. Se estudia la decoración de la iglesia distinguiendo los elementos decorativos reutilizados de los tallados ex profeso para la iglesia, ofreciendo una posible explicación alternativa, postvisigoda, a su datación. Además se analiza su modulación y se propone una reconstrucción de sus partes perdidas.

\section{SUMMARY}

On the basis of epigraphical evidence, construction of the church of San Juan de Baños (Palencia) is usually thought to have been ordered by Reccesvinth in either 652 or 661 . A new ground-plan and a study of the site's stratigraphy show how later restorations relate to the remains of the earliest church. A study of decorative elements makes it possible to distinguish material made expressly for the church from recycled pieces, giving rise to the hypothesis of a postVisigothic date for the original contruction. The internal divisions of the building are also discussed and a reconstruction of its now lost parts proposed.

\footnotetext{
1 La dirección de los trabajos es de Luis Caballero. La planimetría fue realizada en el Gabinete de Fotogrametría Terrestre del Departamento de Historia Antigua y Arqueología, CEH CSIC, por Santiago Feijoo y Fernando Arce, con el asesoramiento de Leandro Cámara. La lectura de paramentos la efectuaron los firmantes del artículo, Fernando Arce, Alaitz Echevarría (Univ. del País Vasco) y Margarita Fernández Mier (Escuela Española de Historia y Arqueología de España en Roma, CSIC), con la colaboración de Leandro Cámara, a quien agradecemos también la discusión y orientación sobre aspectos constructivos. También agradecemos la ayuda prestada por Mariano del Amo y de la Hera, director del Museo Arqueológico Provincial de Palencia (MAP), y Luis Javier Balmaseda Muncharáz, conservador del Dep. Medieval del Museo Arqueológico Nacional de Madrid (MAN). El trabajo forma parte de un convenio de colaboración entre el CSIC y la Junta de Castilla y León y del proyecto del Programa Sectorial de Promoción General del Conocimiento PB94-0062, en el que participan Agustín Azkarate (Univ. País Vasco) y Esther Peña Bocos (Univ. Cantabria). La documentación está depositada en el Dep. de Historia Antigua y Arqueología, CEH CSIC, y en la Junta de Castilla y León.
}

\section{HISTORIOGRAFÍA E INTERVENCIONES RESTAURADORAS}

Es esta iglesia, probablemente, la desde más antiguo reconocida y considerada por su inscripción como de época visigoda. Navascués recoge las citas sobre su dedicación (no todas, a ellas aún hay que añadir la de Mayáns en 1773 citada por Gil), iniciada por su copia en el Códice de Azagra del s. x y luego con regularidad por los eruditos y estudiosos a partir de Ambrosio de Morales en 1577. Los juicios, casi coetáneos, de Mariana en 1592 y de Sandoval en 1601 dan las pautas de los que van a ser argumentos tópicos y reiterativos de toda la ordenación científica de nuestro arte de época visigoda. Primero la autoridad de la inscripción, obra antigua, y al parecer de godos,. . y en él una letra de seis renglones, por lo cual se entiende fue edificado en 661 (Rada 1893: 44 n. ) y, en segundo lugar, la mezcla de los tipos arquitectónicos basilical y cruciforme, edificada en cruz y la nave que cruza entre el cuerpo de la iglesia y los altares (Quadrado 1885: 332 n. 2). Quadrado se apoya en la inscripción para considerarla como la única entera o al menos bastante completa para estudiar en ella el tipo de las construcciones propiamente godas; Baños demuestra la precedencia del arco de herradura visigodo frente al islámico y sirve de precioso eslabón entre las raras antigüedades visigodas descubiertas en Toledo y las construcciones asturianas del $s$. IX, a pesar de lo cual señala los paralelos con lo arábigo (arcos de herradura), asturiano (ajimeces) y bizantino posterior (Quadrado: 331-5). A pesar de que estos juicios se repiten con insistencia, la conservación parcial de esta iglesia y la ausencia de un análisis detallado sobre su arquitectura han impedido resolver, hasta ahora, los problemas que plantea.

Tras los sucesos con que se inició el s. XIX, el monumento debió estar muy cercano a la ruina completa, por la pérdida de su cubierta y la caída de sus muros laterales, como certifican grabados antiguos (los que publican Navascués en su portada y Palol 1988: 8, que lo califica de romántico, 1964: 23). De esta situación crítica salió con anterioridad a 1872 , 
gracias a una restauración de la que apenas tenemos noticias y éstas contradictorias, pero que permitió que llegara hasta nosotros. Efectivamente, en ese año Rada, quizás como consecuencia del viaje que efectúa por encargo de la Comisión de Antigüedades un año antes, publica en Museo Español de Antigüedades una descripción de la iglesia, refiriéndose a una anterior restauración efectuada con escaso criterio y a la que achaca la actual espadaña, aunque de igual forma que la antigua (p. 568; id. 1893: 55-6). Es interesante observar cómo la crítica a esta primera restauración subyace en opiniones posteriores, distinguiéndose de la opinión más favorable que va a tener la de Aníbal Álvarez efectuada después, a caballo de los dos siglos. La de Becerro en 1874 (p. 198-9) es quizás la más dura: habiéndose librado de la ruina en la invasión árabe y en todas las luchas posteriores, no se ha librado de que, con escusa de restaurarlo, lo hayan disfrazado horriblemente por dentro y por fuera. Puede que entonces se cerrara el ábside mayor convirtiéndolo en sacristía, colocando delante un retablo barroco, como lo describe Rada, ya que en los grabados citados aparece abierto y sólo con bancos y gradas pegados a sus muros (1893: 54-5. Ponz 1787: 280, en su capilla mayor.. un infeliz retablo viejo). Pudo deberse esta primera restauración al arquitecto académico A. Fernández Casanova, pero no es seguro dado que Agapito (1902a: 14), a la vez que cita de él un proyecto de restauración (hacia 1865), se refiere de modo genérico a la desgraciada restauración anterior a la de Aníbal a la que atribuye también la actual espadaña. Quizás pueda rastrearse otro indicio de ella en un comentario de Camps Cazorla (1946: 631 n. 15, aunque dèbemos valorar que este autor sólo parece ser consciente de una restauración, la de Aníbal), cuando dice que no debe estar tan.restaurado como la malicia ha querido hacer correr, viendo... un monumento completamente «restaurado» en el peor sentido de la palabra... Salvo en las partes altas, que no he podido apreciar bastante de cerca, no creo que se llegase a desmontar nada del monumento para reponerlo en su sitio. Tampoco ha debido de moverse el epígrafe..., refiriéndose también a la refacción de los muros laterales, que no sabe si efectuada al restaurarse, y, de modo crítico, al rejuntado de los muros y las celosías. Aún a ella se refiere Rollán (p. 23, no demasiado fiable dadas las aparentes equivocaciones que sufre en la fecha del informe de la Comisión de Monumentos, p. 12 y 16), que alude a las ventanas de las naves laterales consecuencia de restauraciones de pésimo gusto que posteriormente cerró Aníbal y a una excavación efectuada en 1844 en que aparece el ara de las nin- fas hoy en el Museo Arqueológico Nacional de Madrid y que pudo coincidir con esta primera restauración (Rollán: 51; Velázquez y Ripoll: 559-61). Según Simón y Nieto, esta restauración tuvo lugar en 1865 y a ella le atribuye los tejados, la elevación en un metro de las naves laterales, la cornisa dórica y la espadaña (Rodríguez y Simón). Con toda esta información coincide la de Rivera (61-2), tomada de Combarros y de la Academia de Bellas Artes de S. Fernando. Palol (1988: 9-11y23) cita, además el informe solicitando la declaración de monumento de la Comisión de Monumentos de Palencia de 1896 redactado por Simón, que nosotros no hemos conseguido consultar y, de modo parecido a Camps, duda de la parte alta de la nave central, con su friso corrido, aunque termina creyéndolo original $o$, por lo menos, una restitución muy acertada y correctá.

Tras esta primera intervención (o primeras), certificada como veremos por la lectura de paramentos, se efectuó otra en los últimos años del siglo que va a ser definitiva para el conocimiento de la iglesia, gracias a la colaboración, no pretendida, de Manuel Agapito y Revilla, arquitecto e historiador de la arquitectura; Aníbal Álvarez, arquitecto y profesor de la Escuela de Arquitectura de Madrid; y Francisco Simón y Nieto, arqueólogo e historiador. El diez de julio o el dos de noviembre de 1896 , la Comisión Provincial de Monumentos de Palencia, de acuerdo con el obispado, solicita la declaración de Monumento Nacional con el informe redactado por Simón, consiguiéndolo por R. O. el veintiséis de Febrero del año siguiente, iniciándose a continuación las nuevas obras de restauración dirigidas por Aníbal, hace ahora un siglo. Esta restauración la conocemos gracias a Agapito que utiliza los planos y una memoria del propio restaurador, que según sus palabras fue solo de limpieza y conservación (Agapito 1902a: 16), quizás en un intento para diferenciarse de la intervención anterior. La restauración estaba prácticamente terminada en 1903 (Agapito 1903-4: 157) aunque fue inaugurada definitivamente el veintinueve de mayo de 1907 (Rollán: 16). A ella acompañaron excavaciones de Simón (citadas entre otros por Fita 1902: 495 por desgracia efímeras en Noviembre de 1898; según el plano de Agapito 1902a: 28, en Abril de ese mismo año), y quizás del propio arquitecto (Lampérez 1908). Con ellas aparecen cimientos que certifican la planta original de la iglesia, según palabras del mismo Aníbal con una lógica irrebatible si bien la planta resulta de lo mas raro y feo que se ha visto, y algunos hallazgos que han pasado casi desapercibidos, una inscripción funeraria y dos sepulcros romanos (Rodríguez y Simón: 17, n. 2), al parecer un triente áureo de Vitiza 
junto a las columnas delanteras (Rodríguez y Simón: 17, n. 4; Palol 1988: 73 ss., según el Informe de Simón) y el inicio de una inscripción con invocación a Cristo en la parte exterior de la basílica y en sitio próximo a la famosa fuente (Fita 1902: 4945, Vives: $314 a$ ). A ello hay que añadir el conocimiento de los datos documentales sobre la iglesia, gracias al Informe de la Comisión de Monumentos, obra de Simón según reconocen todos sus coetáneos deudores de él, pero transmitidos por Agapito quien además ofrece los de los libros de visita y de fábrica (Agapito 1902a: 8-14; id. 1903-4 ${ }^{2}$ ).

Asegurada la restauración de la iglesia, la de la fuente cercana se fue realizando años más tarde. En 1920-5 se construye la escalera, en 1941 se descubren la bóveda y los arcos y en 1961, al quitar la reja que Aníbal puso rodeando a la iglesia, se aprovecha para cerrarla (Rollán: 54).

Aceptada la verosimilitud de su planta y de lo que restaba de su alzado, sin embargo quedaba la duda de su verdadera cronología. Paralela a la polémica dedicada a la primera restauración parece correr otra, aún más soterrada, referente a su adscripción cultural, que debió centrarse en la autenticidad de la inscripción y su coetaneidad al edificio y en la precedencia de los arcos de herradura visigodos a los musulmanes. Sin embargo sólo conocemos de esta supuesta polémica la opinión de los autores reconocidos que siguen la opinión consensuada y que sólo suelen referirse a la opinión contraria de modo genérico para rechazarla. Cossio en 1892 presenta los arcos de herradura de Baños como un problema, preguntándose si son originales visigodos o reconstrucción del $s . x$. En el II Congreso Internacional de Arqueología Cristiana, celebrado en Roma en 1900, se promovió una discusión acalorada e interesante sobre el monumento debida a las comunicaciones de Rodríguez y Simón, lo que dio lugar a un nuevo informe de Simón en que defiende tanto el origen visigodo del arco de herradura islámico como la cronología visigoda de la iglesia por el brioso argumento de la inscripción y de sus características constructivas. Por los mismos años Caveda (recogido por Agapito 1902a: 12) supone la iglesia una simple restauración de las primitivas fábricas, cuya antigüedad, según todos sus caracteres, no puede pasar de los últimos años del s. $X$ o de los primeros del $x I, \ldots$ porque hay alli algunos vislumbres de un orientalismo que nunca los godos conocieron, lo que obliga a Agapito a demostrar la anterioridad del arco de herradura a su uso árabe, cu-

${ }^{2}$ Hay que añadir los datos sobre la inscripción árabe aportados por Ponz, De La Rada y Quadrado y algunos otros datos por Gómez Moreno y Rollán. Todo lo resumimos en el anexo 1 . riosamente apoyándose en paralelos y no en la cómoda autoridad que a los demás proporciona la inscripción. Por otra parte, la dificultad de interpretación que ésta presenta, centrada en la palabra decies, hace dudar de toda ella. Así lo indica Agapito (1902a: 10 n., del caracter de autenticidad... que pudieran hacerla más moderna) y esta polémica traspasa nuestras fronteras de modo que en el célebre Dictionaire d'Archeologie Chretiènne et de Liturgie, Leclercq insinúa que la inscripción debe ser mucho más tardía, del s. XII (Navascués: 17 y 48). Finalmente, unos y otros extrañan la situación de la inscripción que, por su altura, impide su lectura. Así lo indica de nuevo Agapito (1902a: 36) y sobre todo Puig (p. 35, n. 1) quien, pese a mantener la fecha visigoda de la iglesia aunque retrasa las de las demás consideradas visigodas, sintetiza todas las dudas de esta forma: ... sobre la clave del arco triunfal, emplazamiento extraño para una inscripción, en un lugar donde la lectura es imposible. Es indicio probable de una restauración. La inscripción de Recesvinto y la iglesia misma son muy discutidas. El mismo Navascués lo observa con objetividad, a pesar de defender su visigotismo y convertirse así en autoridad de su antigüedad: resulta su lectura difícil y penosa, agravada por la escasez de luz (p. 6).

Todas estas dudas, y quizás otras que quedaron en el ámbito de lo privado, servirían de acicate para impulsar la defensa de su visigotismo en dos líneas principales. La definitiva que del arco de herradura visigodo efectúa Gómez Moreno (1906: 802-3, fig. 12-3), luego reforzada por el estudio que de su modulación hace Camps (1953: 22, fig. 4-6), y la del visigotismo de la inscripción que efectúa Navascués en 1961. De esta manera se puede decir que se cierra una etapa con el reconocimiento de que Baños es la pieza clave para definir la arquitectura visigoda. Prácticamente después nadie se va a atrever a poner en duda su cronología. Sólo resta redondear el argumento. Baños es el modelo del arte visigodo tanto para Schlunk (1947: 273-280) como para Gómez Moreno (1966: 123-4, lám. VII), sin que apenas necesite demostración, a pesar de lo cual el primero no deja de señalar sus paralelos con lo mozárabe y lo asturiano. Tras certificar con su data la teoría de la miniatura visigoda (Schlunk 1945: 253-4 ${ }^{3}$ ), el descubrimiento de un fragmento decorado con la inscripción del Credo en Toledo sirve para relacionar su decoración con la que se hace en su territorio, S. Pedro de La Mata, o en los centros que de ella dependen, Lisboa, S. Pedro de La Nave (Za-

${ }^{3}$ Supone que en el disco de una de las piedras salientes existe una inscripción con dos o tres letras. 
mora) y Quintanilla de las Viñas (Burgos. Jorge 1957; Schlunk 1970: 175-186 y lám. 54-60). Hauschild (273-4, fig. 4a, lám. 42-3), en su estudio de la técnica constructiva de sillares, incide en la misma línea relacionándolo con La Nave y Quintanilla, sobre la que en la actualidad redunda Arbeiter.

Pasados los años, el edificio necesita mantenimiento. Así se inicia una tercera fase de intervenciones que va a suponer, además de un importante avance en su conocimiento, la apertura lenta e indecisa de nuevos caminos en su explicación, gracias al análisis arqueológico que efectúa Pedro de Palol. Como en la anterior, también participan ahora arqueólogos, siempre dirigidos por Palol, junto a arquitectos que desgraciadamente van continuamente variando. En 1950 A. Arenillas recalza los muros de cabecera, reconstruye en piedra obras de ladrillo de restauraciones anteriores, entre ellas al parecer contrafuertes, sustituye el suelo del atrio por losas, rejunta las grietas de los ábsides laterales y reteja; en 1956 se reparan las cubiertas por F. Íñiguez y A. Arenillas, a la vez que se sondean arqueológicamente los cimientos de los ábsides laterales desaparecidos, con la colaboración de Wattenberg y García Guinea; en 1961, L. Cervera adapta el monumento al turismo y se continúan las excavaciones a lo largo de la parte N.; y en 1963 se hace una explanación para el aparcamiento delantero y se excava, con la colaboración de Martín Valls y Ordax, la necrópolis N. donde se encontraron varios fragmentos de escultura decorada, un asa de jarrito litúrgico y dos broches liriformes (Palol 1964: 3-5). En 1968 de nuevo Arenillas, que achaca los daños a las excavaciones realizadas, recalza los cimientos del lado N. (y quizás también los del lado S. ), rehace las cubiertas de las naves laterales y de la cabecera y las esquinas exteriores del atrio, coloca la acera alrededor de la iglesia y repara las ventanas. En 1980 I. Sanz Fernández reteja y anuncia su proyecto de rehacer el solado de la iglesia y aplomar la espadaña, de lo que, según sabemos, se efectúa en 1982 lo primero aprovechándose para, con la colaboración de Tuset y Cortes, excavar la mayor parte de su interior (Palol y otros 1983: 243-5. Expedientes del Ministerio de Cultura).

Estos trabajos le sirven a Palol (Palol y otros: 245) para comprobar que la iglesia no se construye sobre ningún edificio previo y certificar la planta de Aníbal y los argumentos tradicionales; pero, a la vez, para observar algunas características del edificio que, manteniendo la cronología tradicional, le plantean dudas sobre la realidad del edificio. Ante todo, Palol es consciente de la necesidad que el edificio tiene de un estudio en profundidad que, a pesar de sus intentos, no llega a desarrollar (1983:
244). A la vez observa una serie de irregularidades en que nadie había reparado (con la excepción de Rada 1893: 53 cuando señaló que los círculos de las impostas de las pilastras, por su irregularidad, mejor pueden calificarse de elipses). En partes del friso del presbiterio hay una cierta discontinuidad de sus elementos; falta de unidad de la decoración, entre el ábside central y los laterales; los llamados canecillos, cuya función de tales no es nada segura, ni tampoco la colocación original; el encuentro constructivo entre las arquerías y el arco de triunfo; y una rotura desarmónica de estructuras en la unión de la cabecera con el cuerpo de la iglesia. Todo ello le sugiere reutilización de elementos preexistentes; restauraciones o quizás aditamentos o errores de colocación; y el problema de la contemporaneidad de las dos o tres partes principales de la iglesia, presbiterio, aula con el pórtico y ábsides laterales, planteando, sino dos o tres momentos constructivos, un intento de renovación de planta y alzados (Palol 1964: 22-4; 1968: 126; 1988: 23 y 53). El descubrimiento de la iglesia de Sta. Lucía del Trampal (Cáceres) le ofrece además un paralelo para explicar su forma y su función litúrgica, aunque no termina de imaginar en ella los cimborrios tan característicos de la nueva iglesia (1988: 21 y 1989: 2015-8).

Uno de nosotros (Caballero 1987: $72-5$ y 1989: $115)$ criticó la relación entre Baños y El Trampal porque tienen profundas diferencias constructivas y, también, la diacronía entre las partes de la iglesia de Baños porque los distintos estilos en las iglesias altomedievales siempre los hemos considerado propios de la manera de hacer de este momento y no un indicio de momentos diferentes. Pero más adelante veremos cómo hoy, apoyándonos en otras evidencias, nuestra postura sobre Baños sigue de cerca lo apuntado por Palol. Finalmente, el estudio estilístico de la decoración de Baños nos hizo plantear de nuevo su cronología postvisigoda, obligando a señalar una contradicción por hoy de difícil resolución (Caballero 1994-95: 112-6 y 1997: 257). Este análisis está alentado justamente por esta contradicción, no pretendiendo resolver con él su cronología, sino aportar nuevos datos que ayuden en el futuro a resolverla.

\section{LA LECTURA DE PARAMENTOS}

Si el problema que se planteaba a la hora de leer la iglesia de La Nave (Caballero y Arce 1997: 223) era el de analizar un edificio cuyo traslado había supuesto la transformación de todos sus contextos históricos en uno solo contemporáneo; en Baños las sucesivas restauraciones y sobre todo la última del 

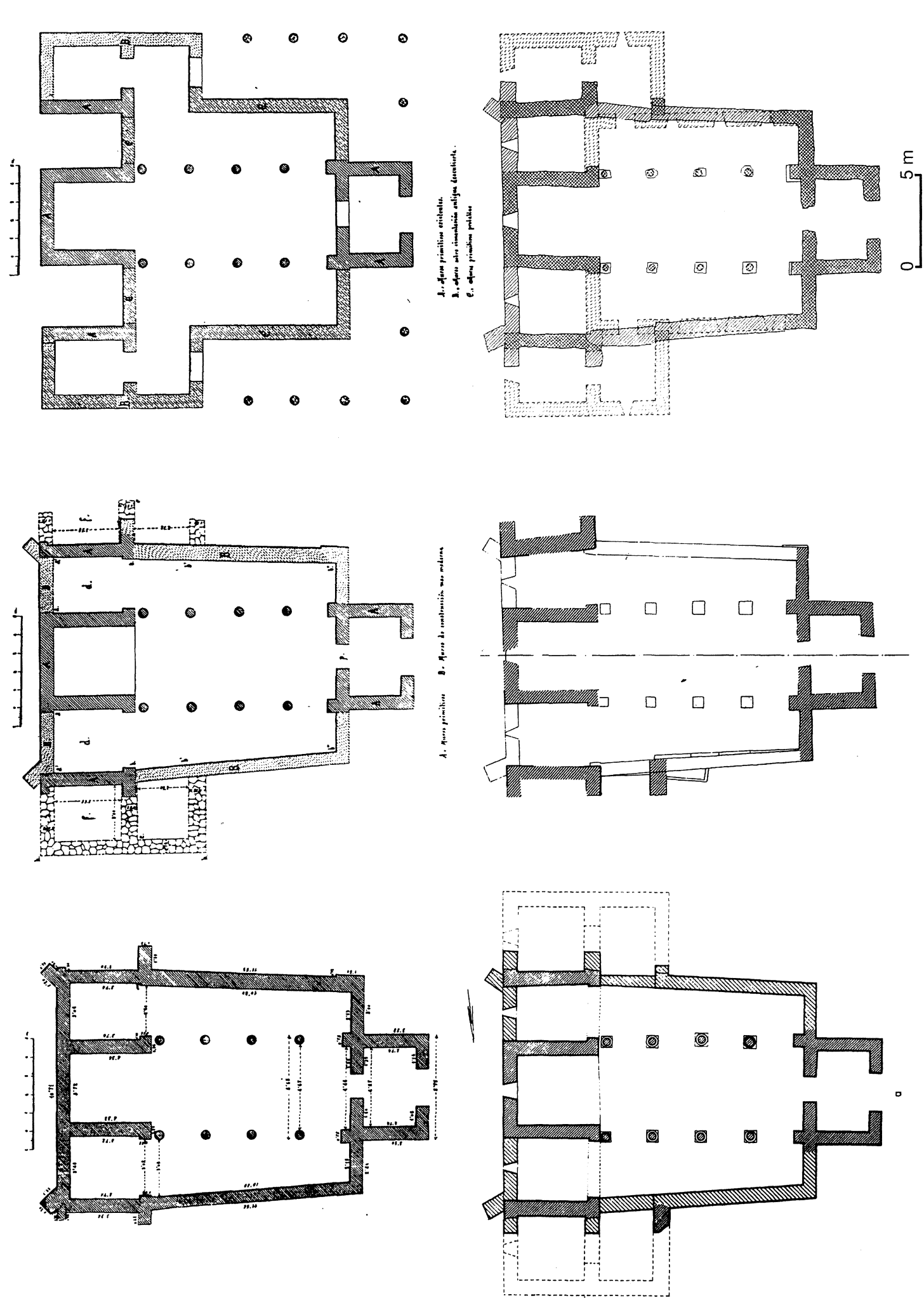


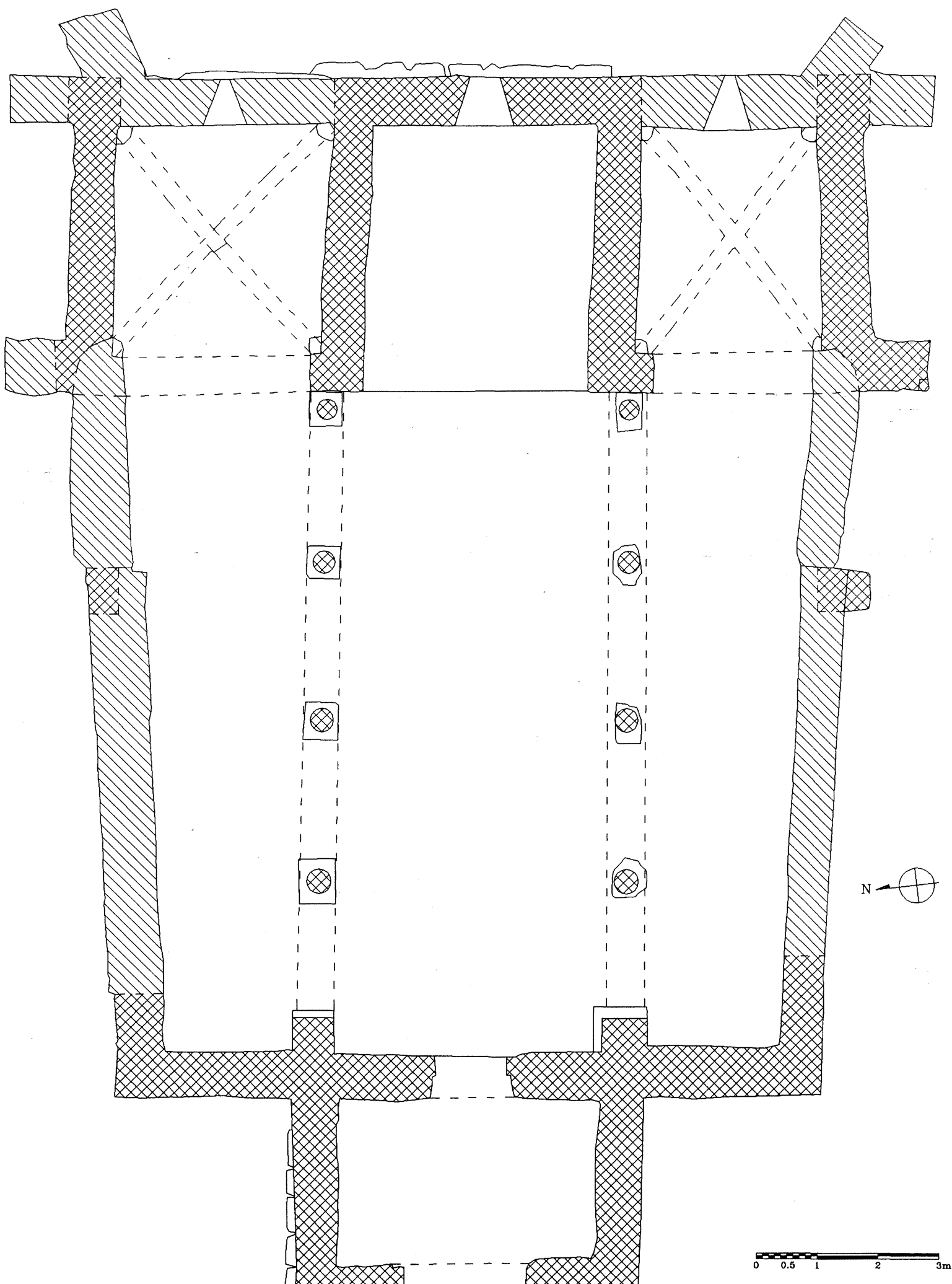

Fig. 2.-S. Juan de Baños. Planta. Escala 1/100. 
arquitecto Arenillas suponen la cubrición con enfoscados de las unidades y las interfaces del edificio, por lo que es difícil, más en su interior, discernir sus diferentes etapas (recordemos los continuos rehinchados y enlucidos desde el s. Xvi y las quejas que hace Camps de los enfoscados restauradores del s. XIX!). Nuestro trabajo supone por tanto una primera etapa en la lectura del edificio, pero sigue necesitado de una segunda fase en que se levanten estos enfoscados históricos y modernos, diferenciándolos, confirmando y corrigiendo la propuesta de lectura que aquí efectuamos. Esta segunda y definitiva lectura ha de hacerse, con andamios, mejores medios y en estrecha colaboración con un arquitecto que proyecte una nueva intervención en el monumento. El delicado pero lamentable estado en que se encuentra necesita una restauración cuidadosa efectuada por un buen experto, que limpie sus ensuciadas superficies (reivindicación de Camps hace cerca de 60 años), resuelva su grave mal de piedra, repare los problemas estructurales de su cabecera, agrietada y abierta, y recupere en lo que todavía sea posible su imagen, al menos diferenciando la cubierta del aula de la de los ábsides, y retirando, si es posible, los contrafuertes no históricos, aprovechando para descubrir algo más de lo que debajo de ellos quede primitivo.

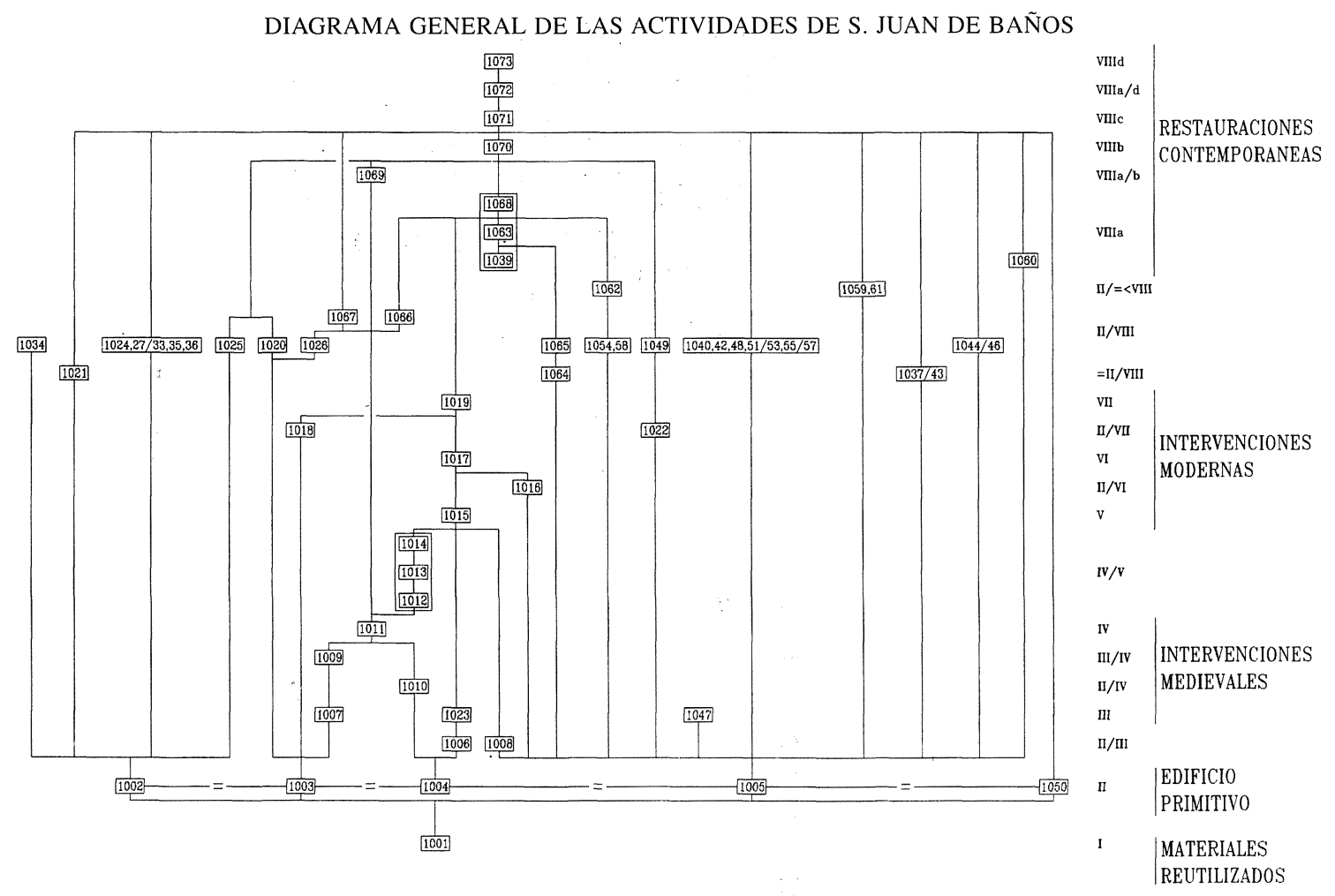

La lectura sigue las mismas normas que la efectuada en La Nave (Caballero y Arce 1997: 223), con la única diferencia de haber intentado simplificar los signos utilizados para encuadrar los elementos sin etapa determinada, usando una / para los que son posteriores (o mayores) que una etapa y anteriores (o menores) que otra.

Período I. Indicios de materiales reutilizados (A 1001, fig. 5-6 y 14)

Con una iluminación rasante es posible ver que el salmer y las dovelas $1^{\mathrm{a}}, 4^{\mathrm{a}}, 6^{\mathrm{a}}$ y $8^{\mathrm{a}}$ del lado Sur del arco de triunfo presentan en su tercio más próximo a su línea de intradós ligeras concavidades que parecen el fondo de huecos para gafar que hubieran sido rebajados (fig. 14). Si estos huecos hubieran servido para elevar estas dovelas lo lógico es que se situaran en el extremo distal de modo que cabecearan a favor de su colocación, no junto a su borde inferior. Tampoco parece lógico utilizar huecos que obligaran a retallar toda la superficie de la pieza una vez colocada. Además, sistema semejante no parece necesario en este caso por el tamaño pequeño de las dovelas y la escasa altura a que se colocan, aunque tampoco se puede decir que fuera extraño su uso. 


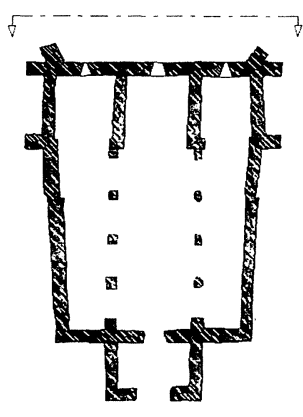

里

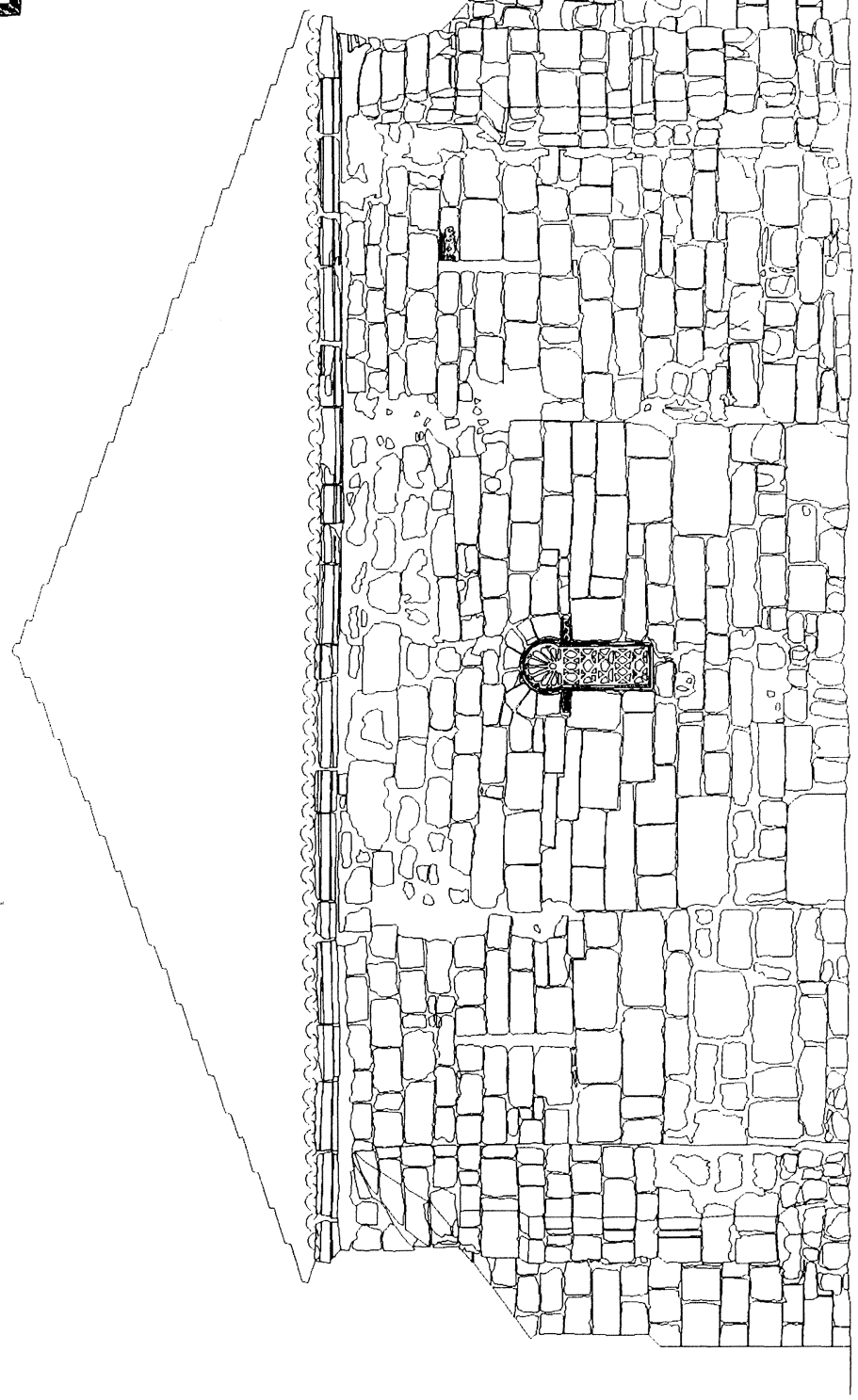

$$
\pi_{0}^{2}
$$




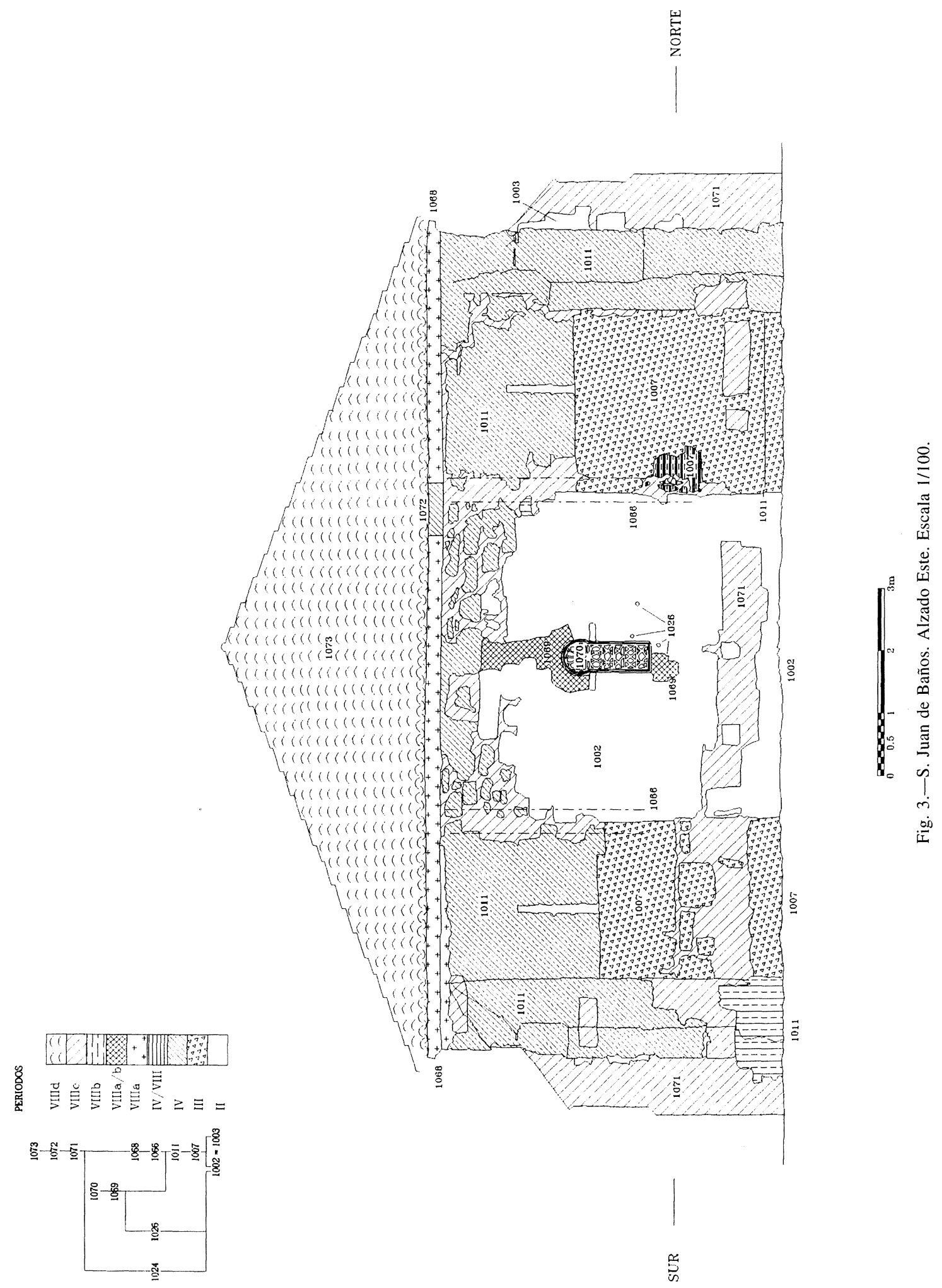



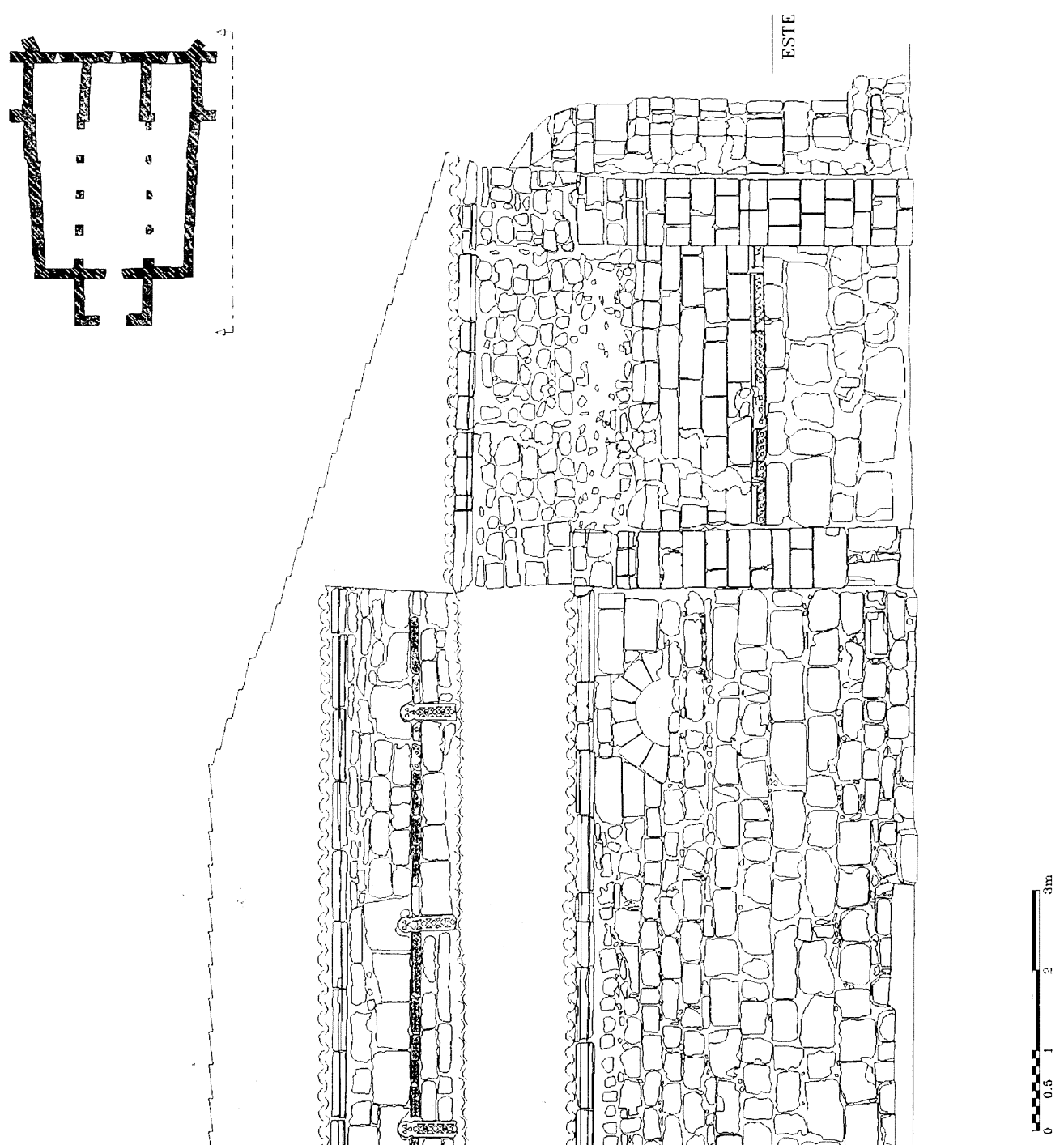

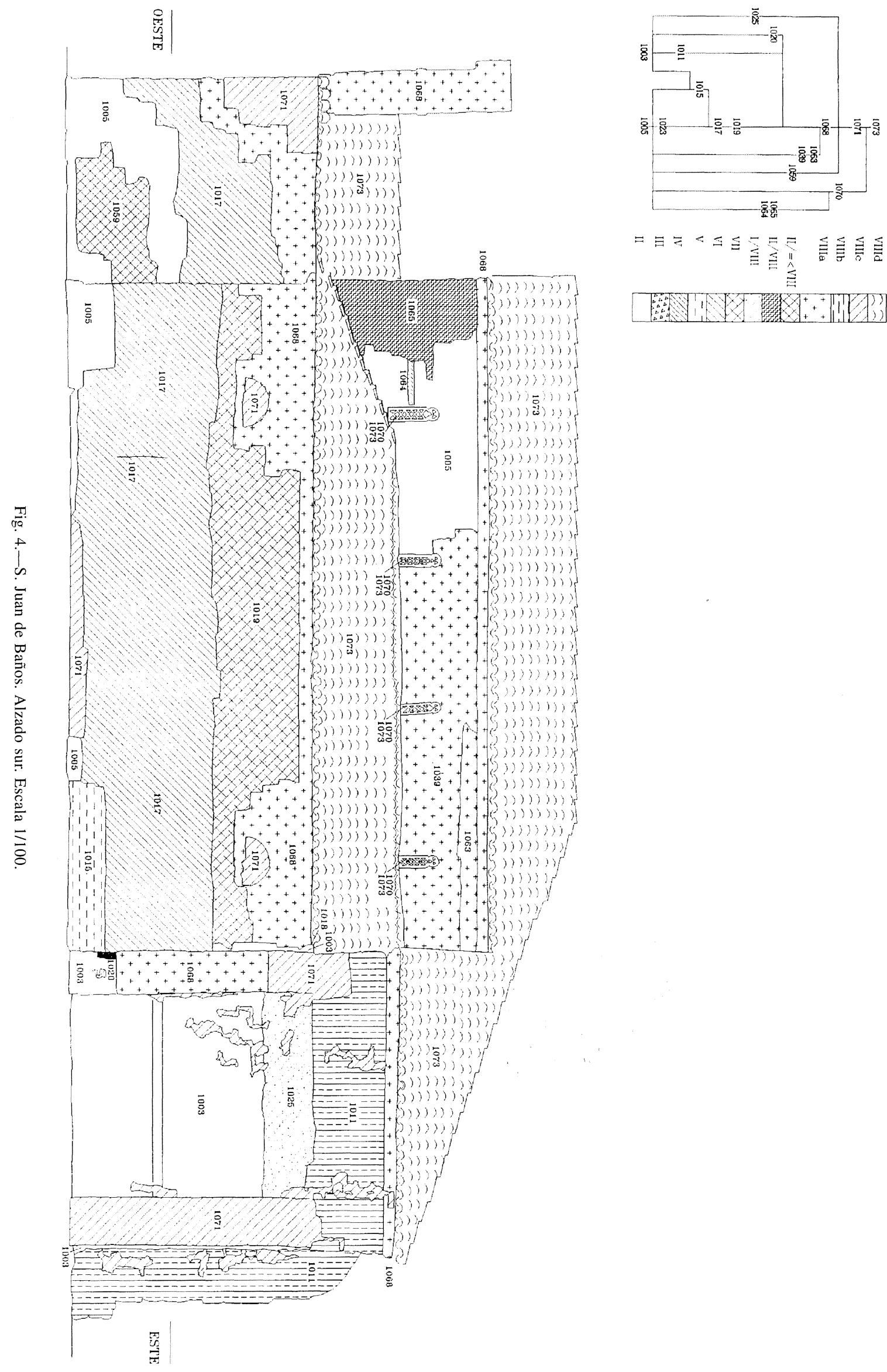

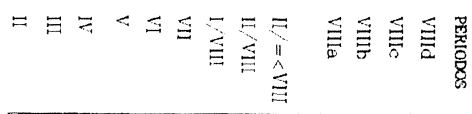

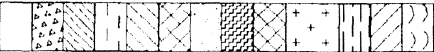



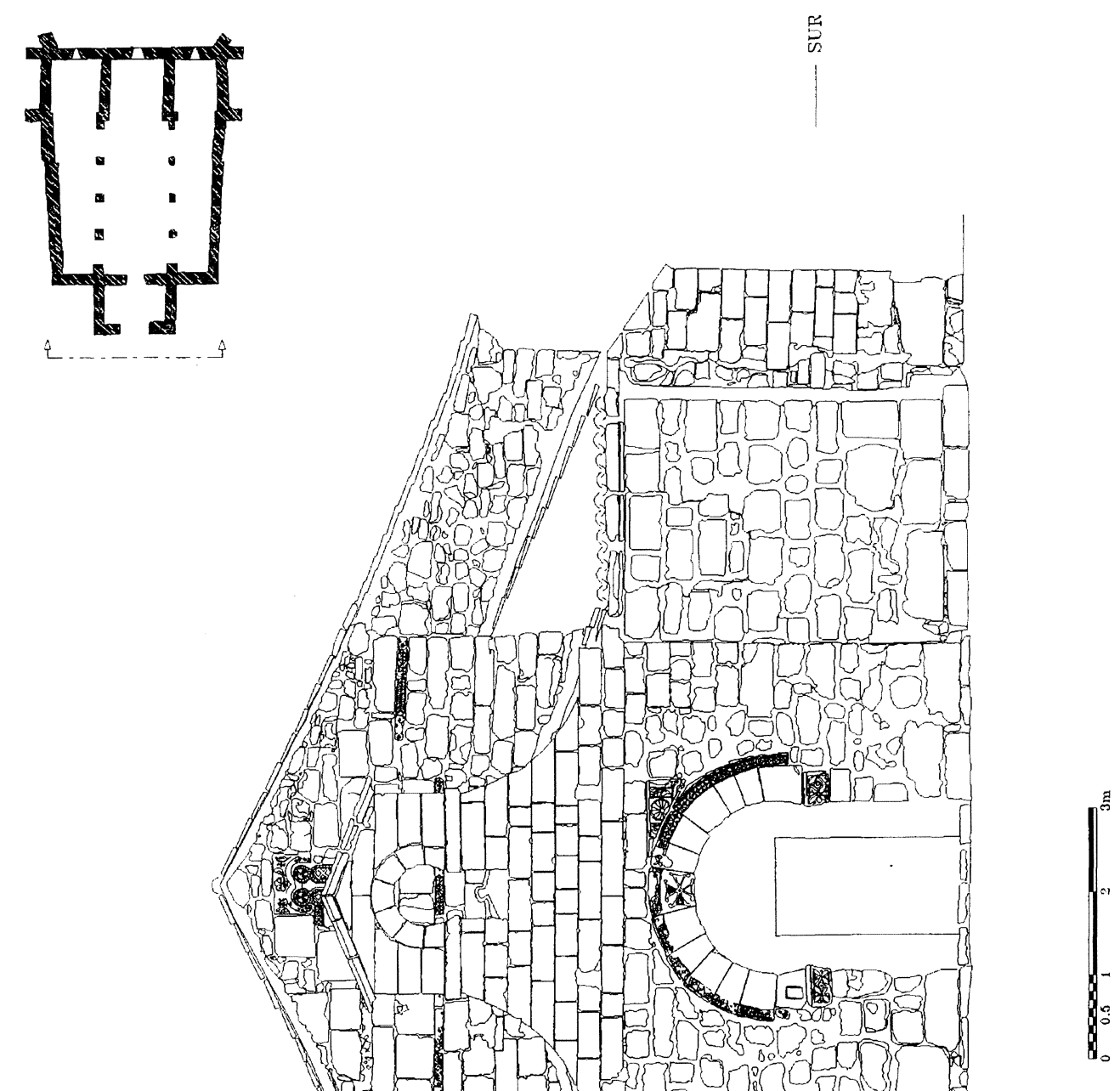


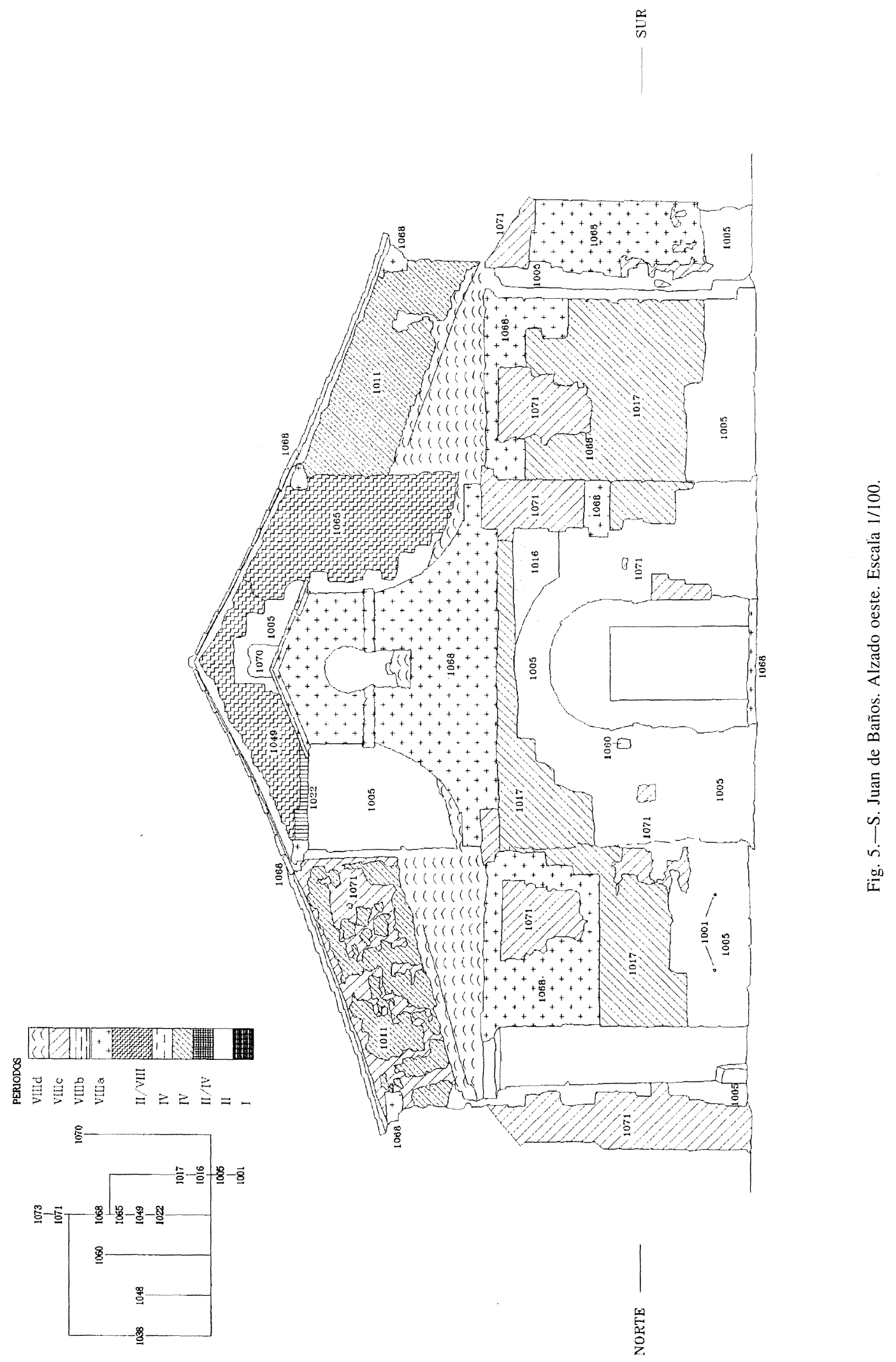



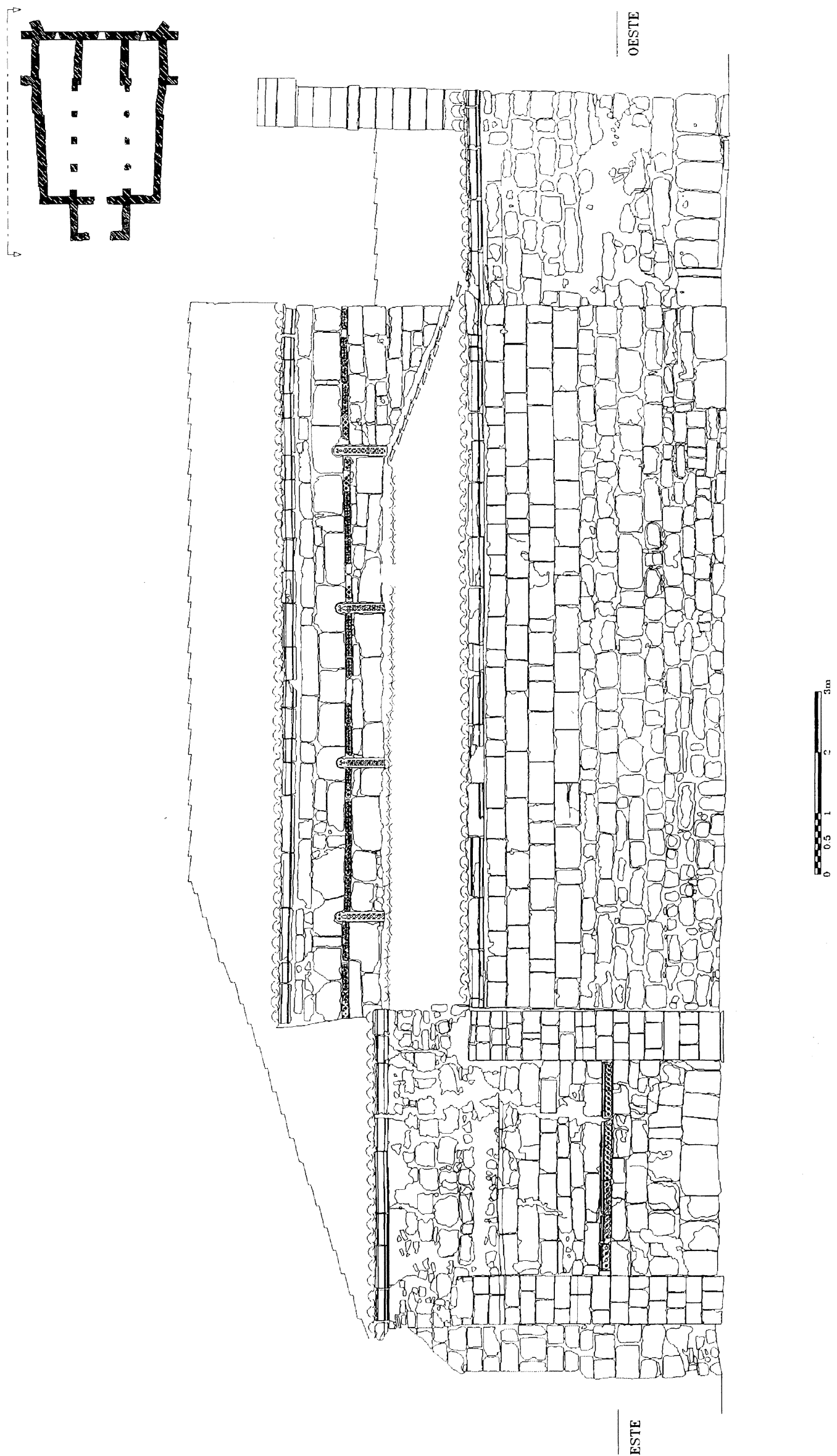


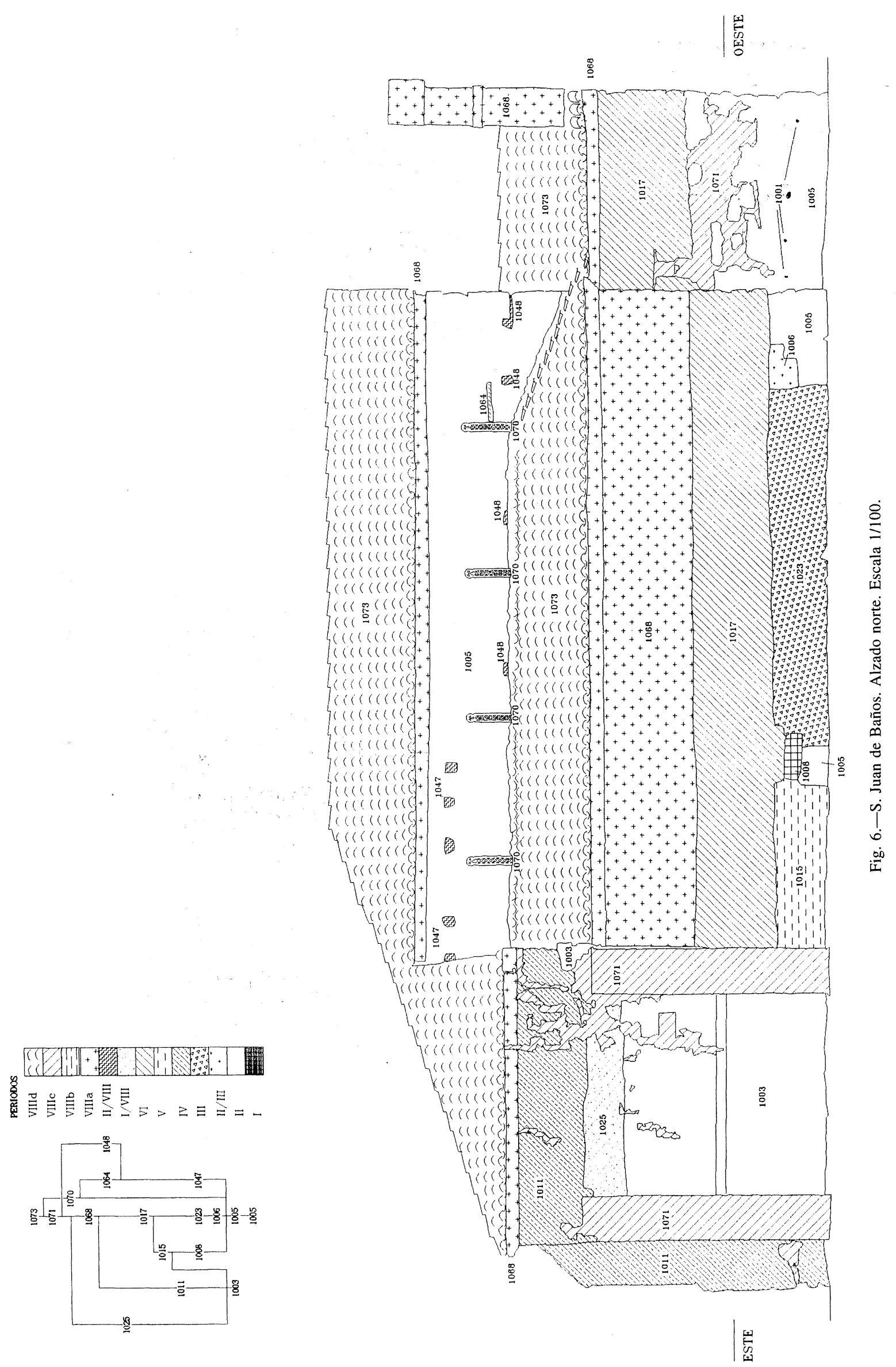



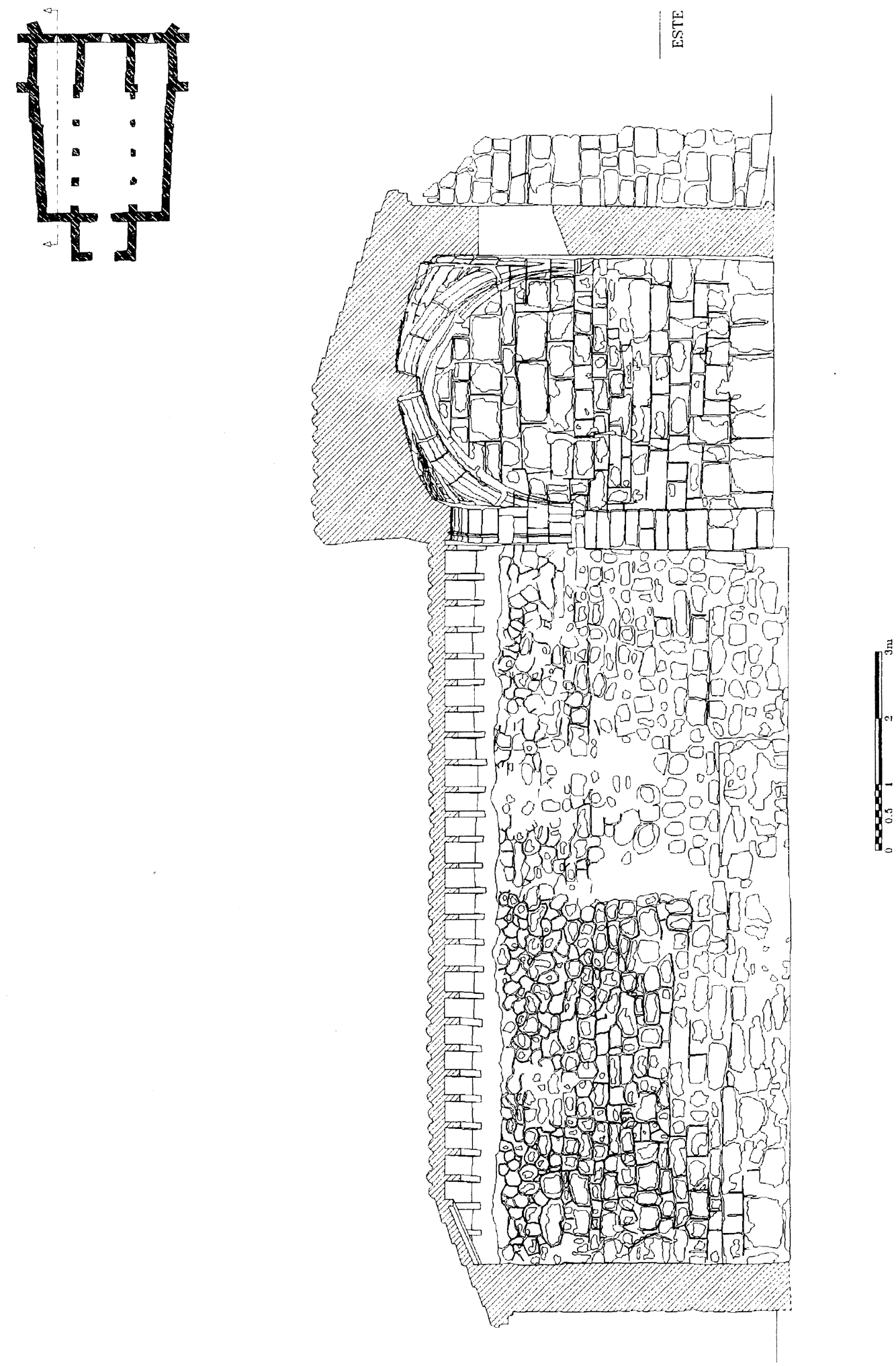


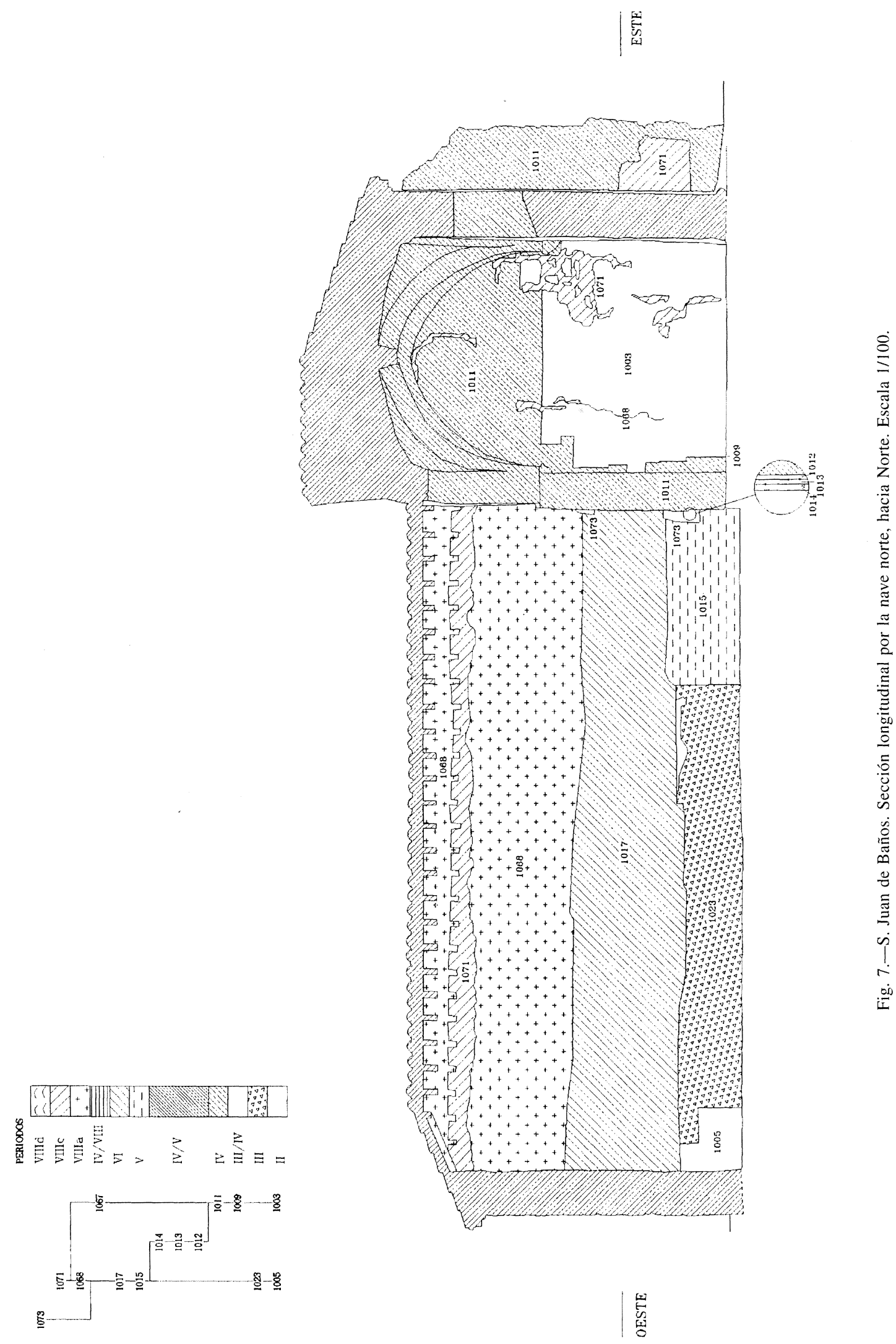



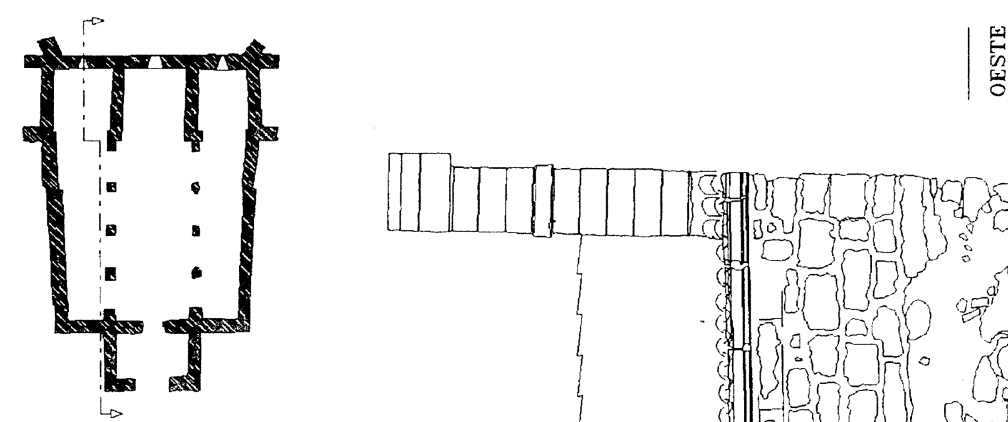

包

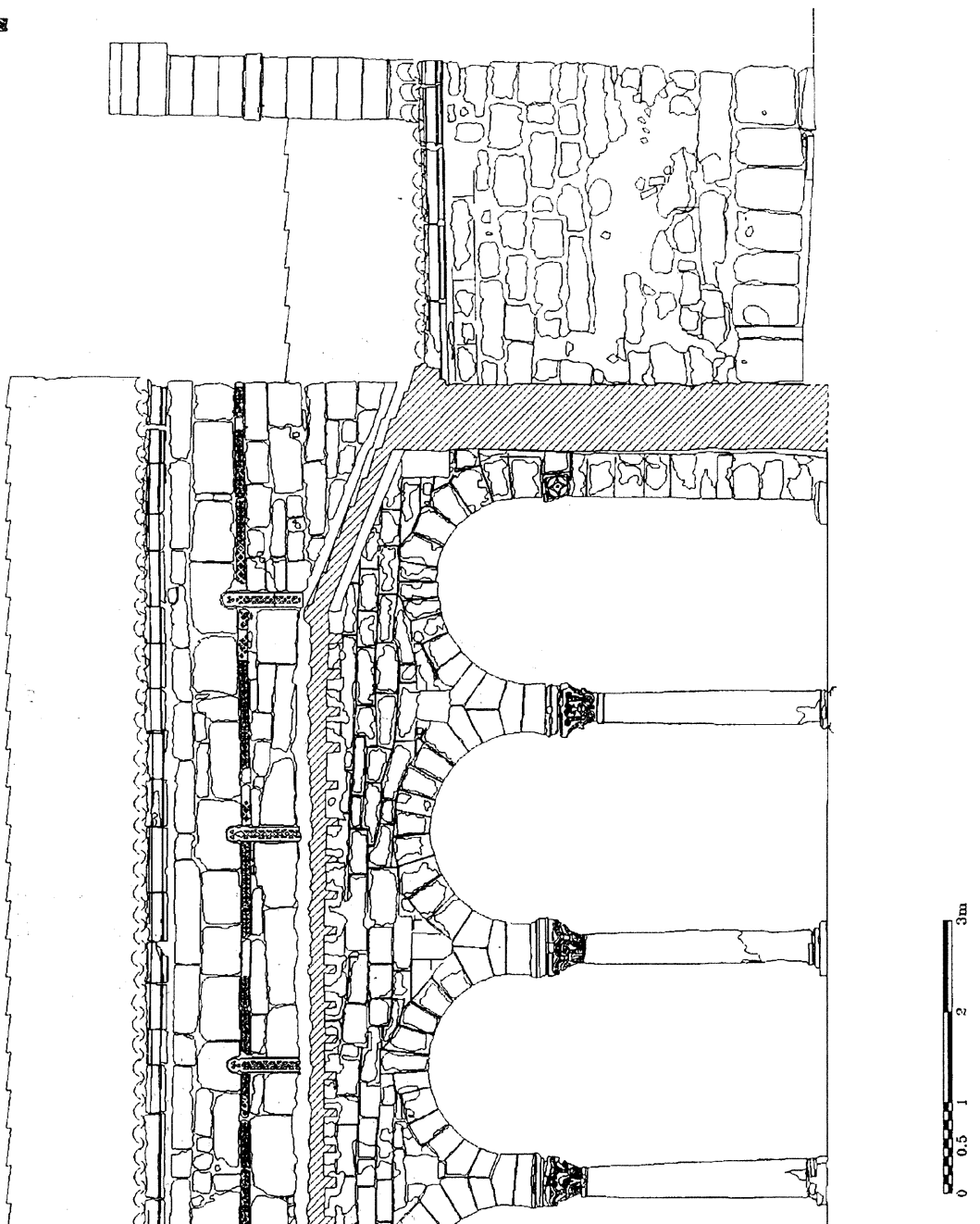




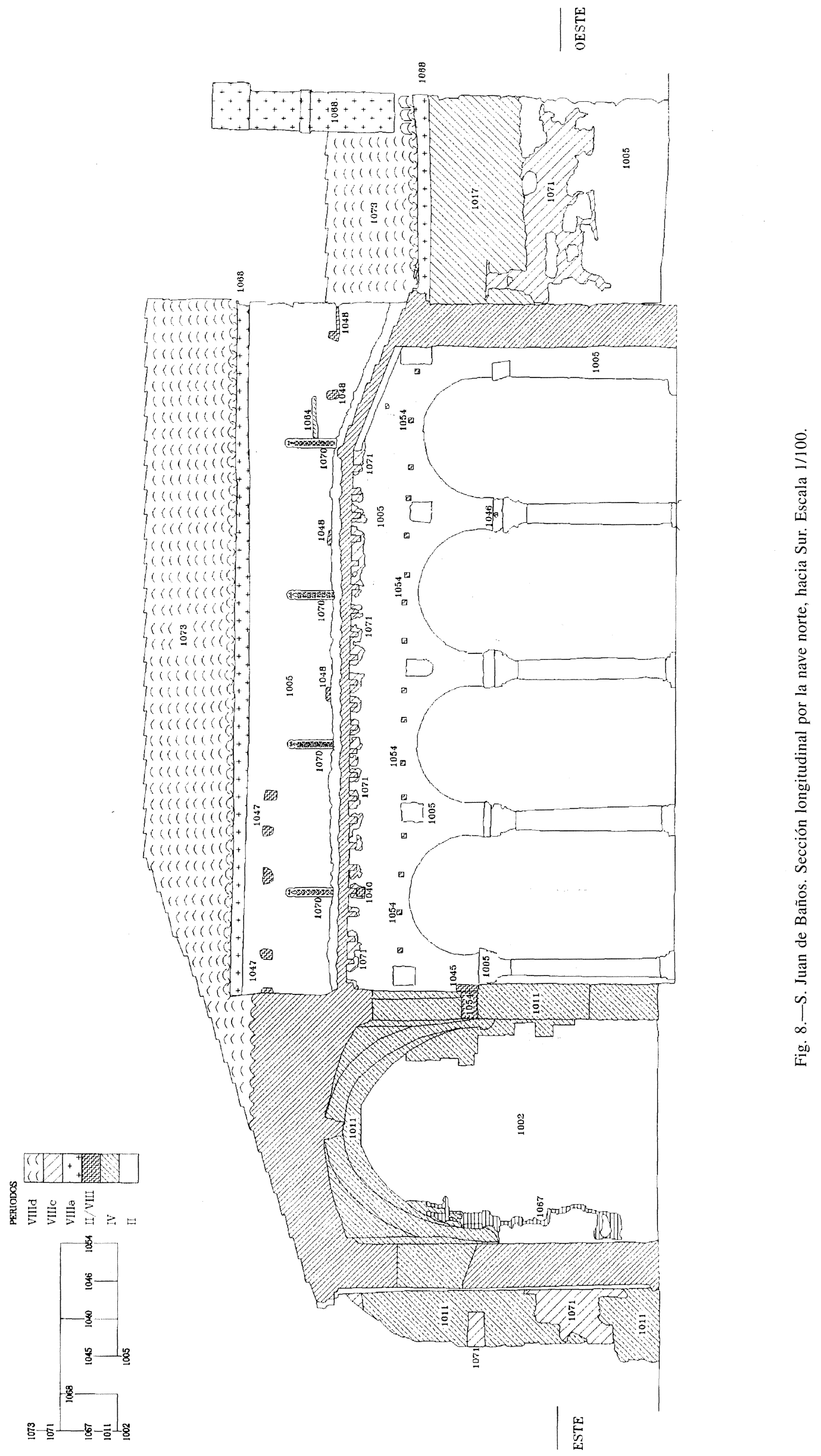



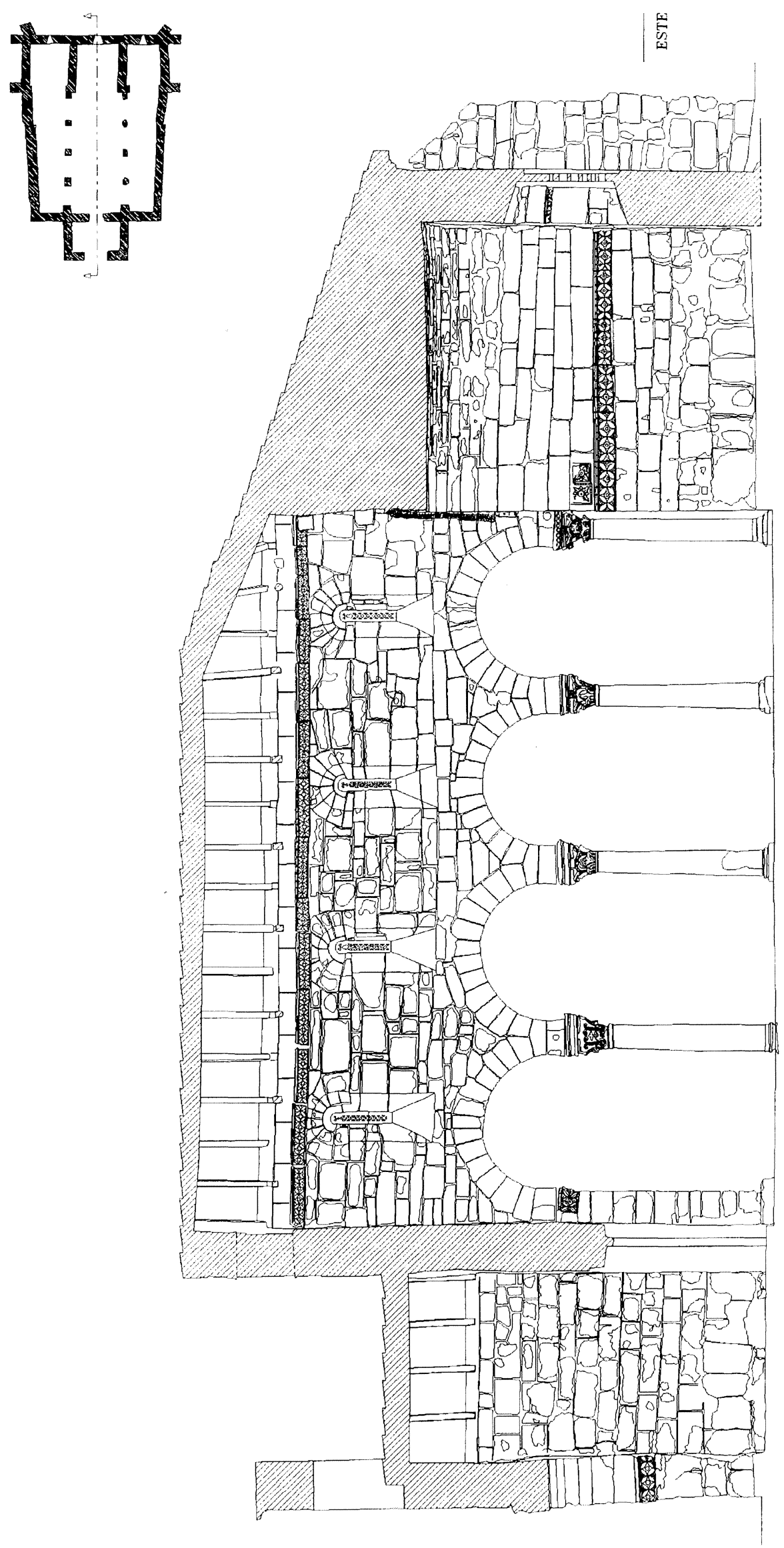

$$
\int_{0}^{3}
$$




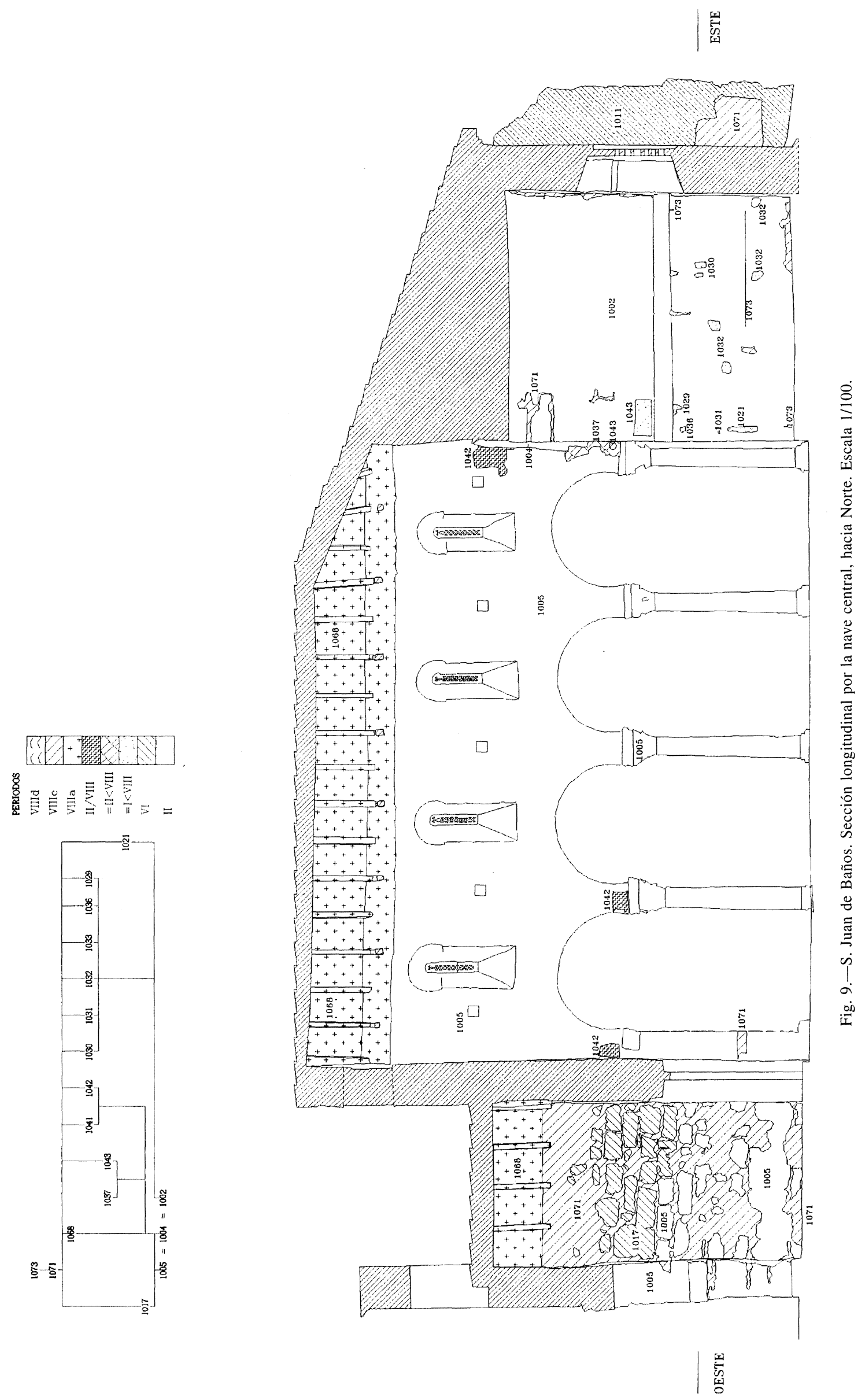



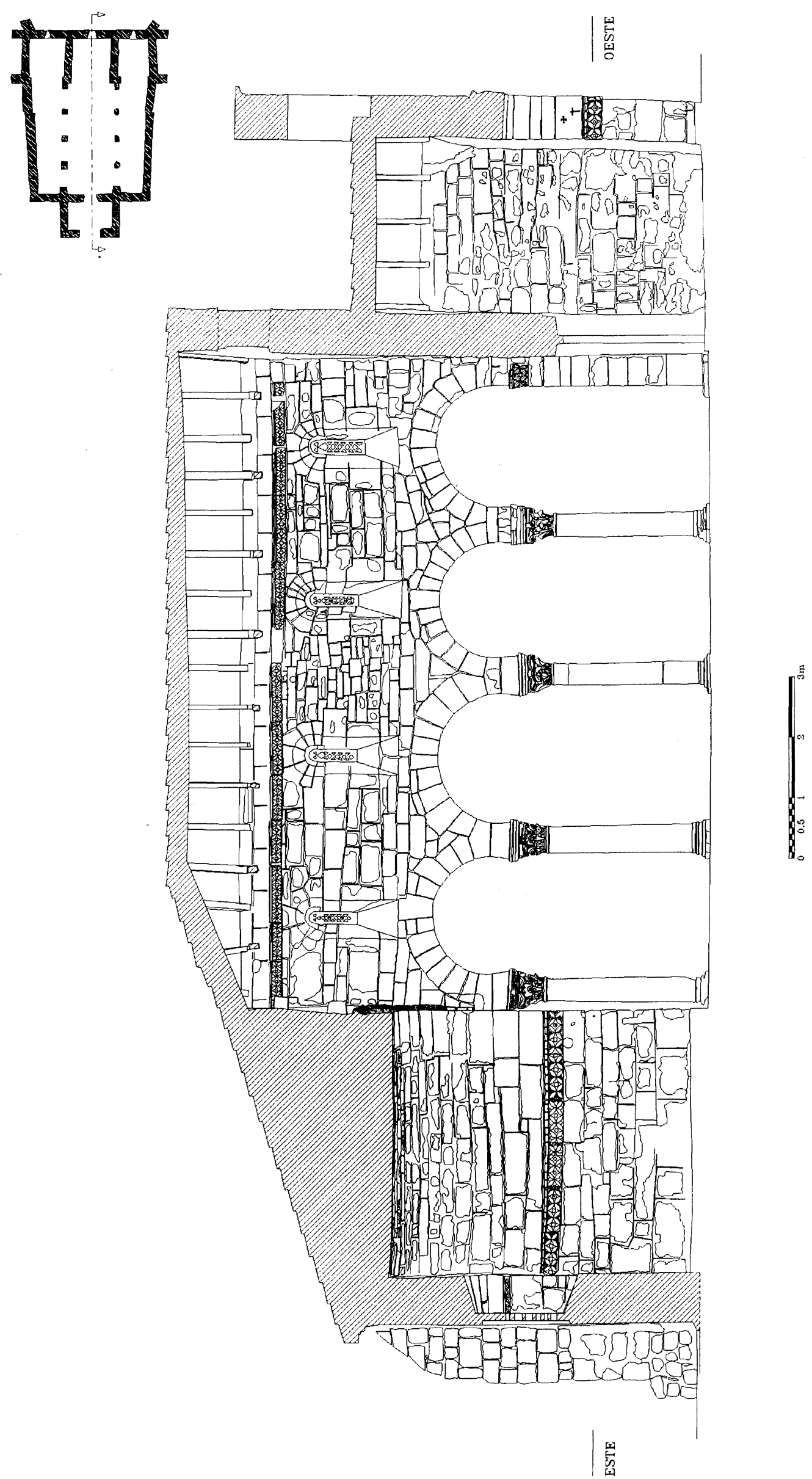


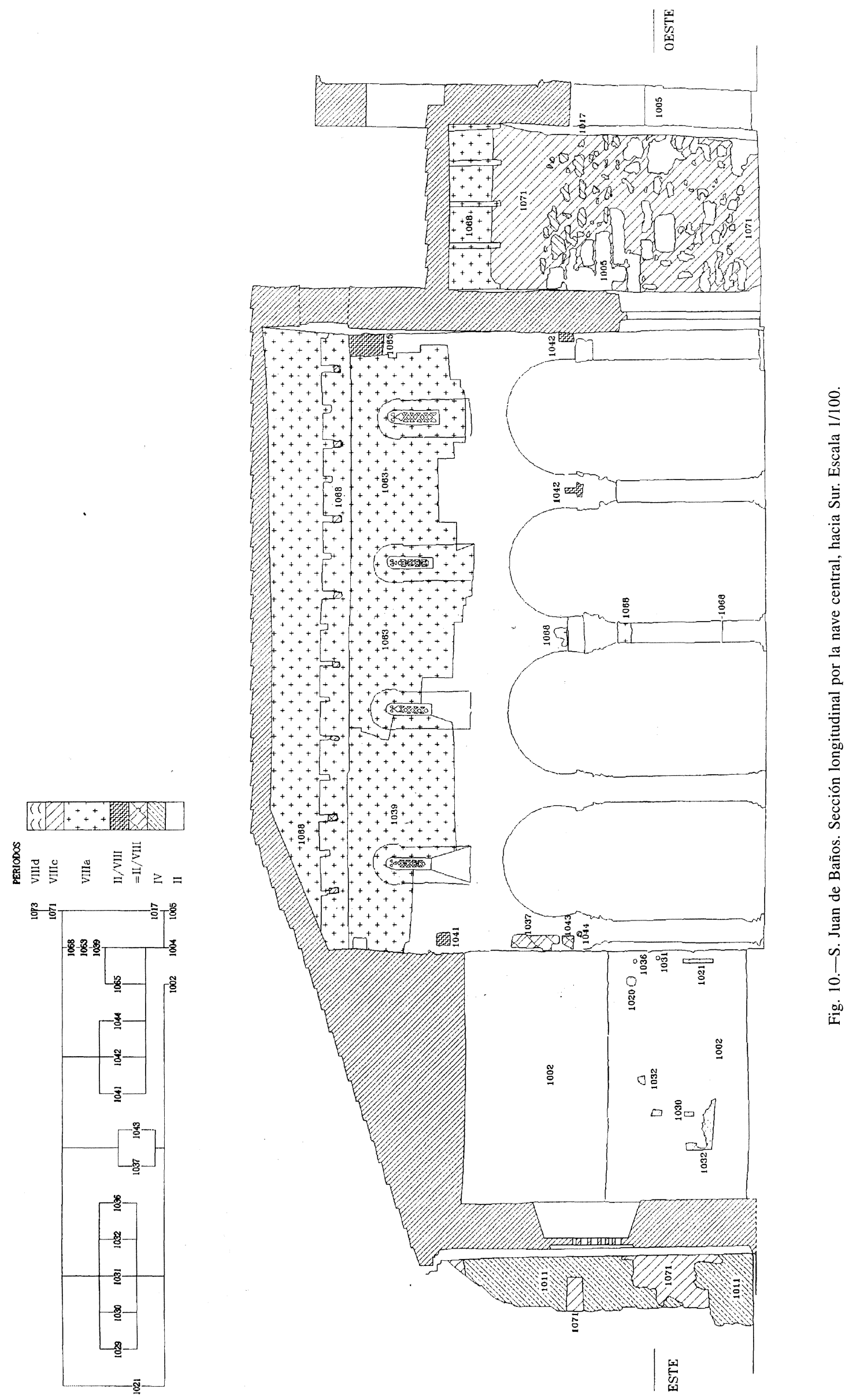




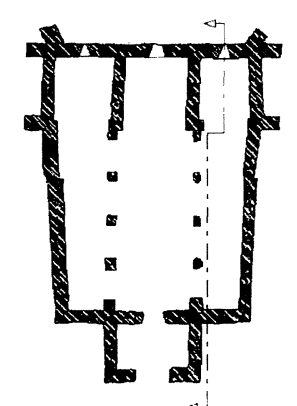

|
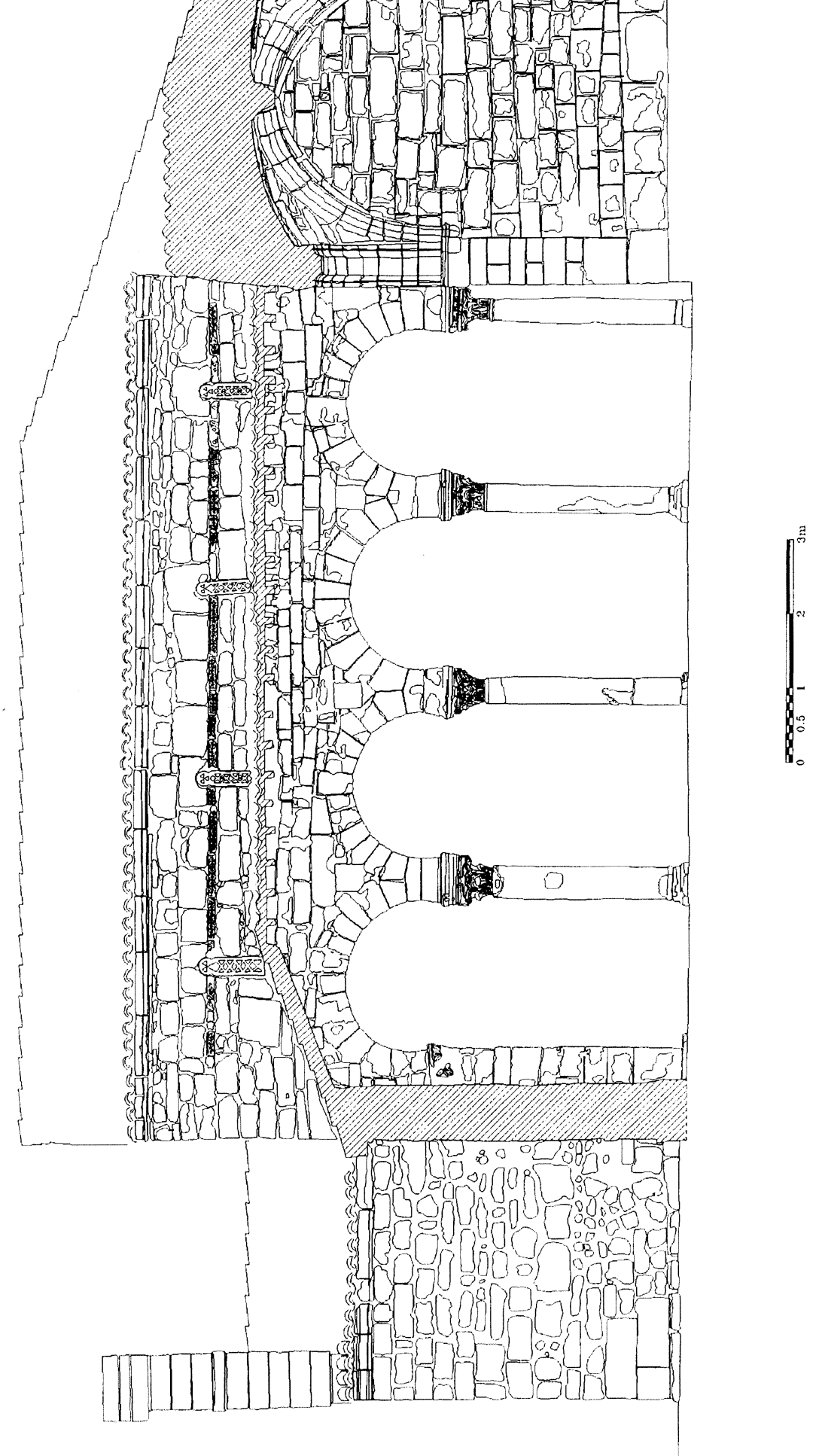

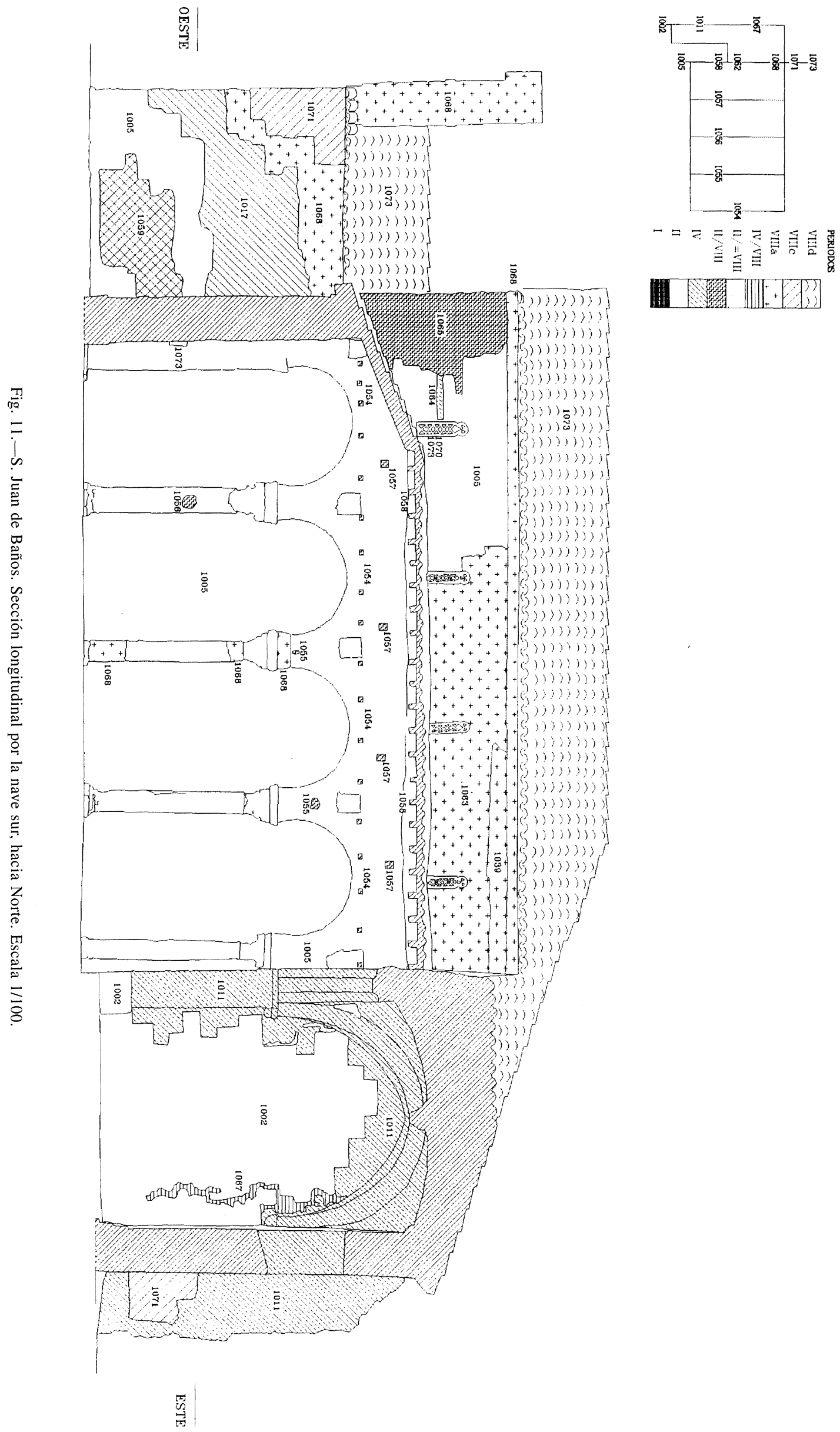

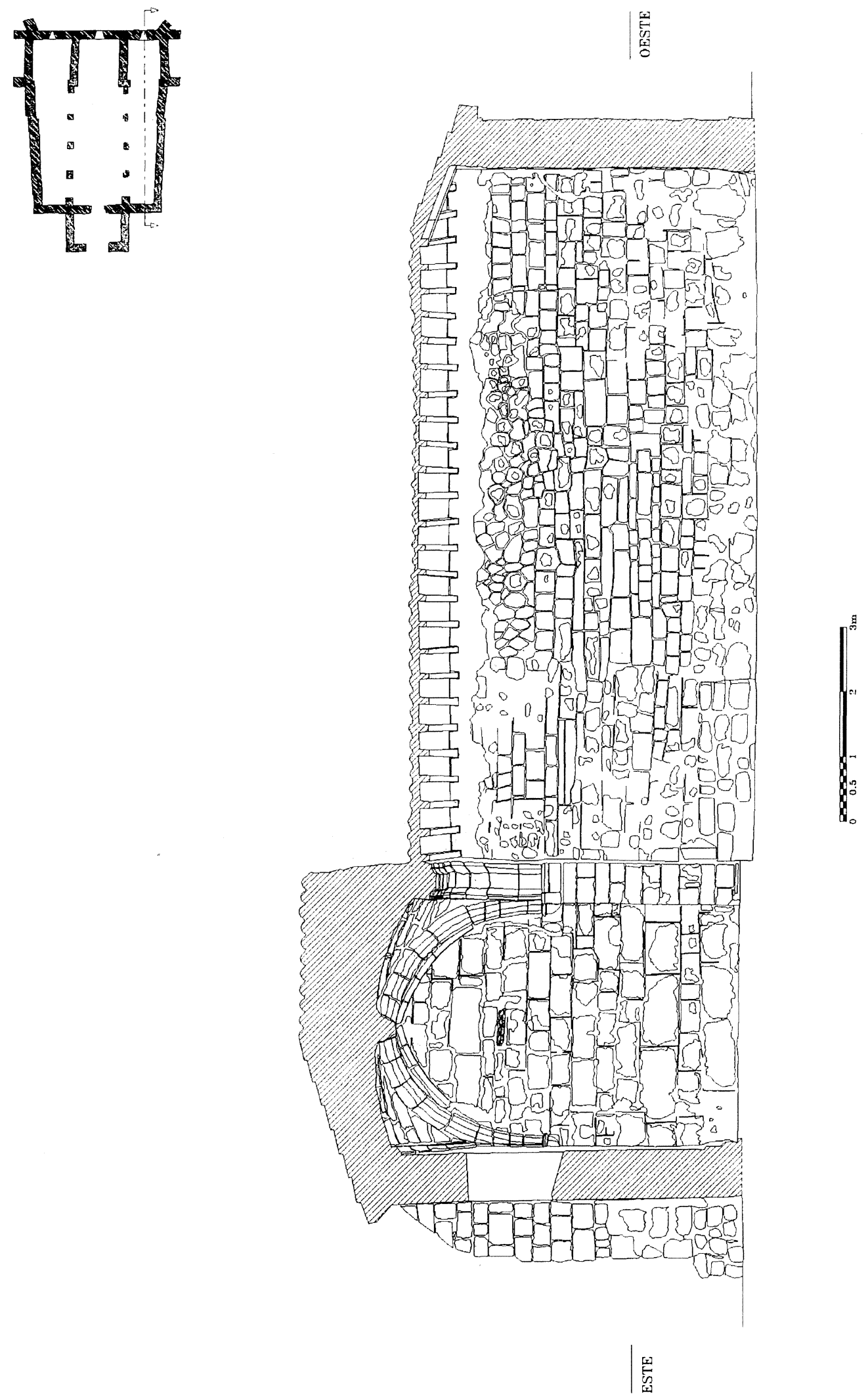


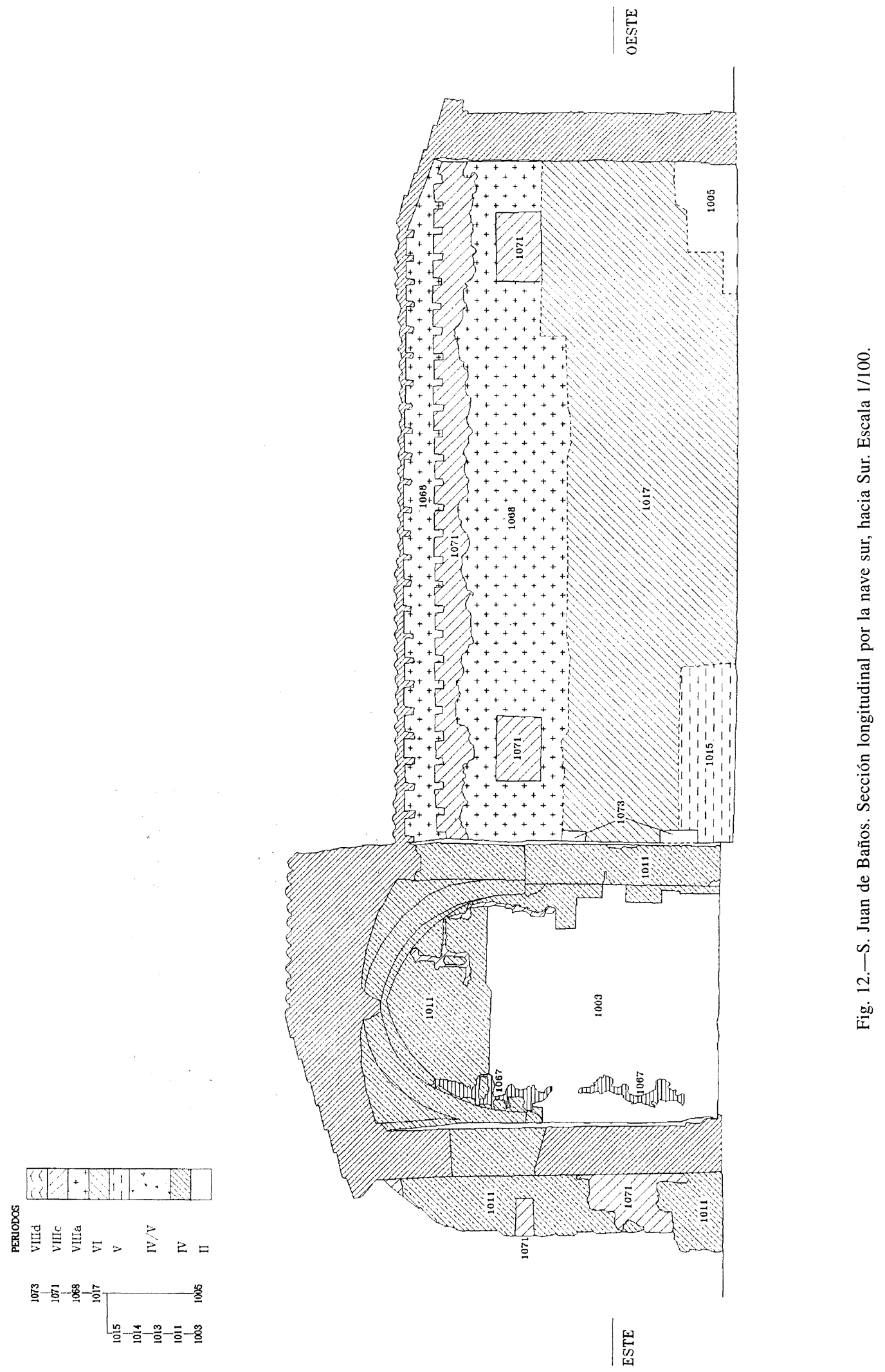



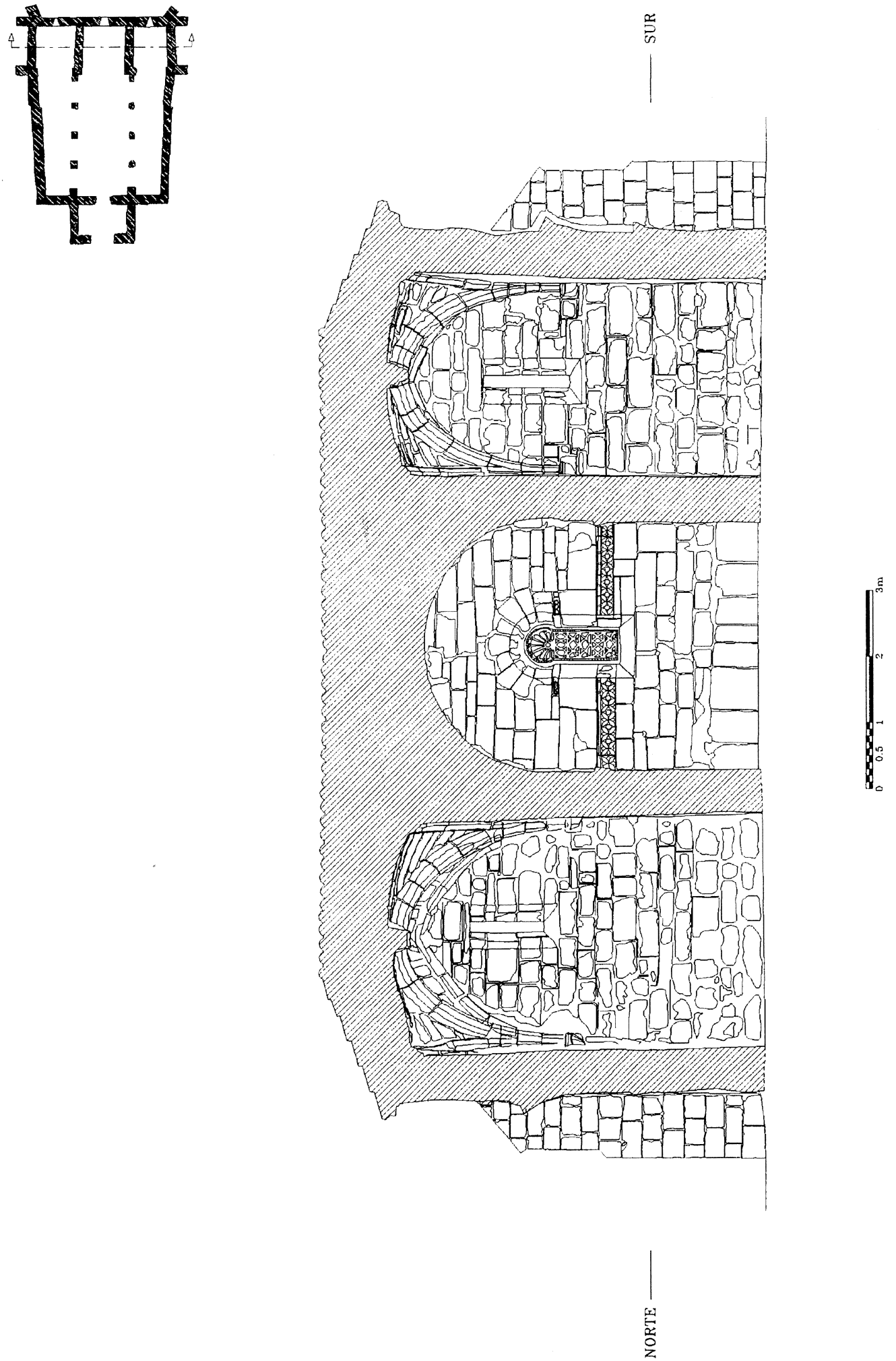


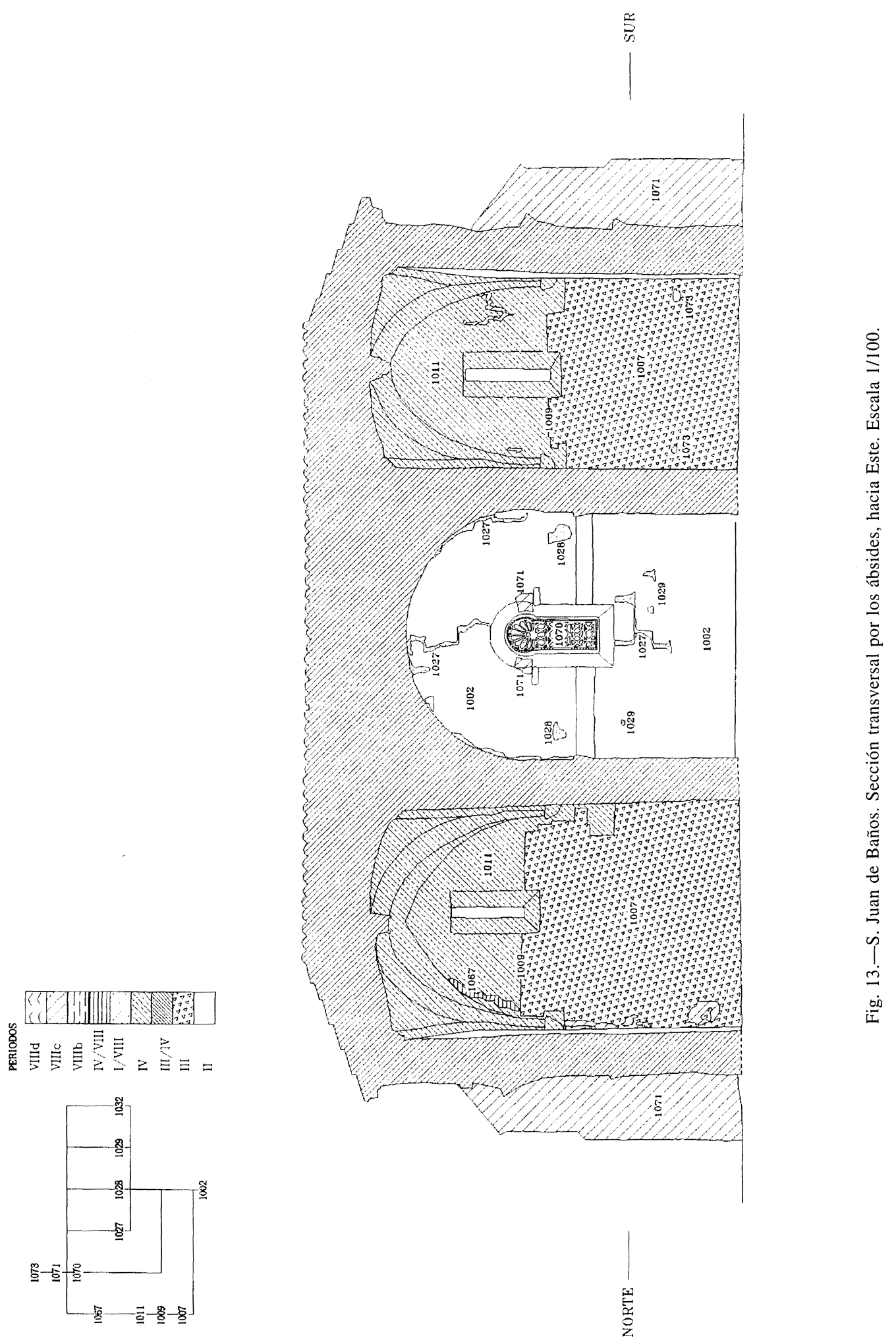



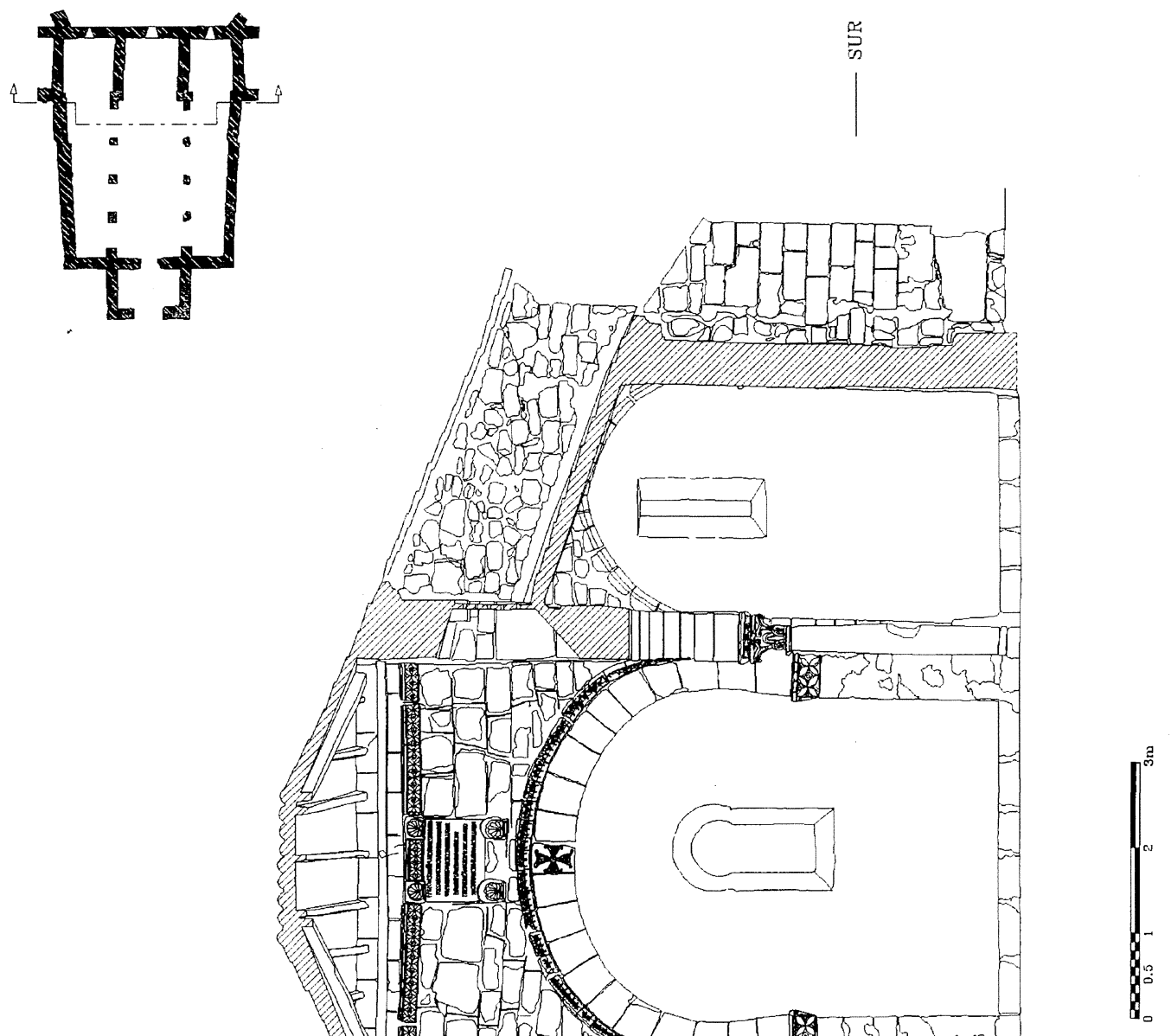


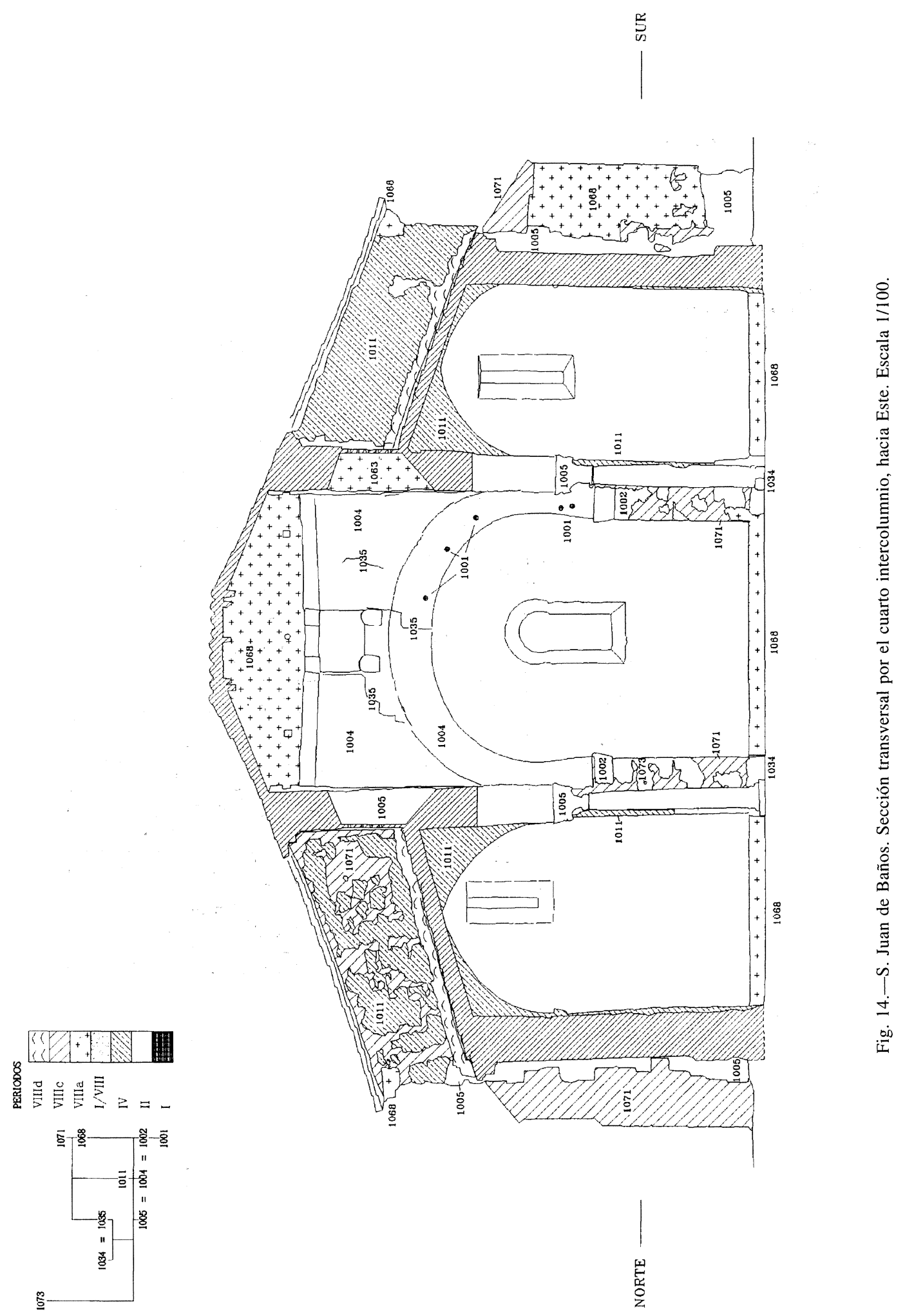



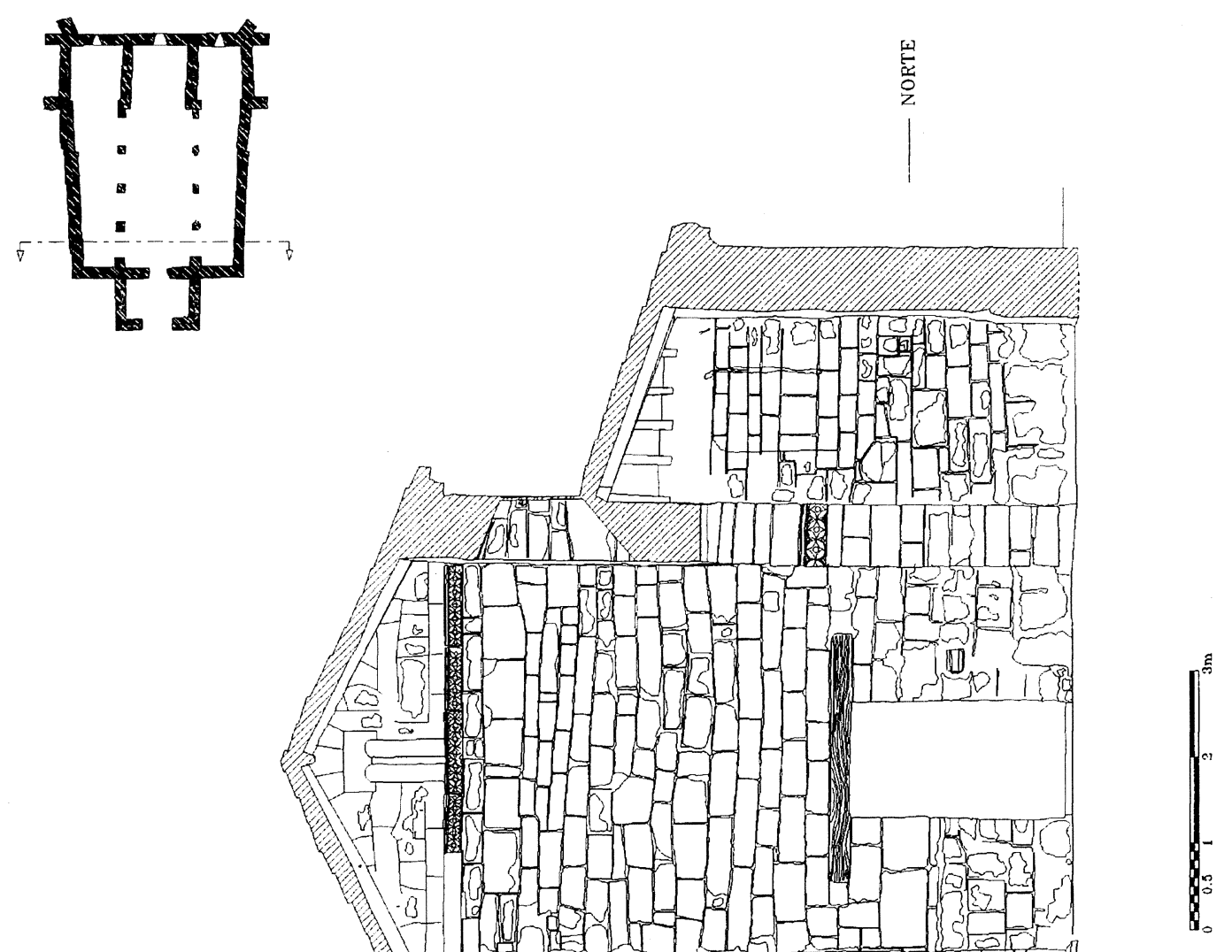


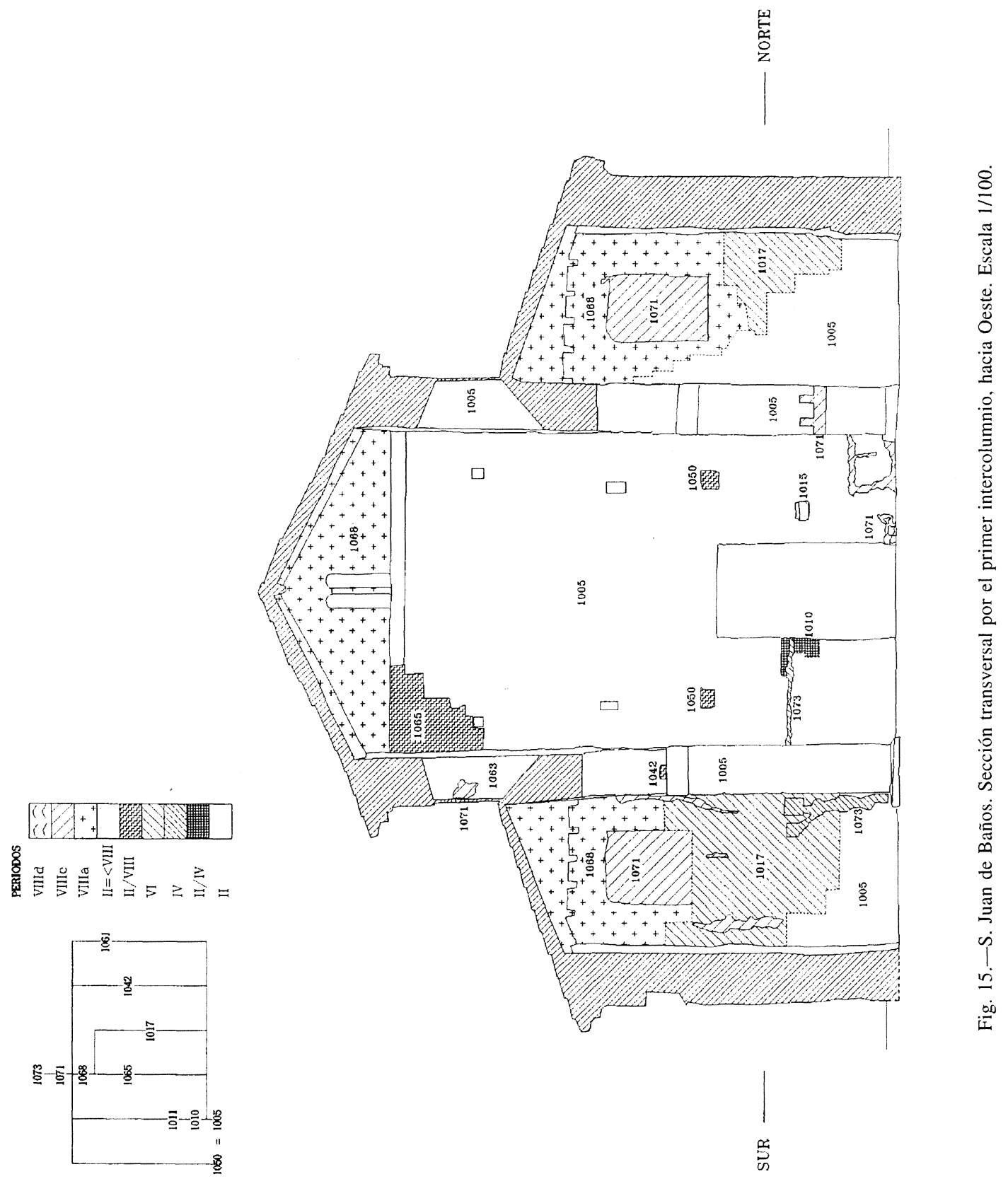



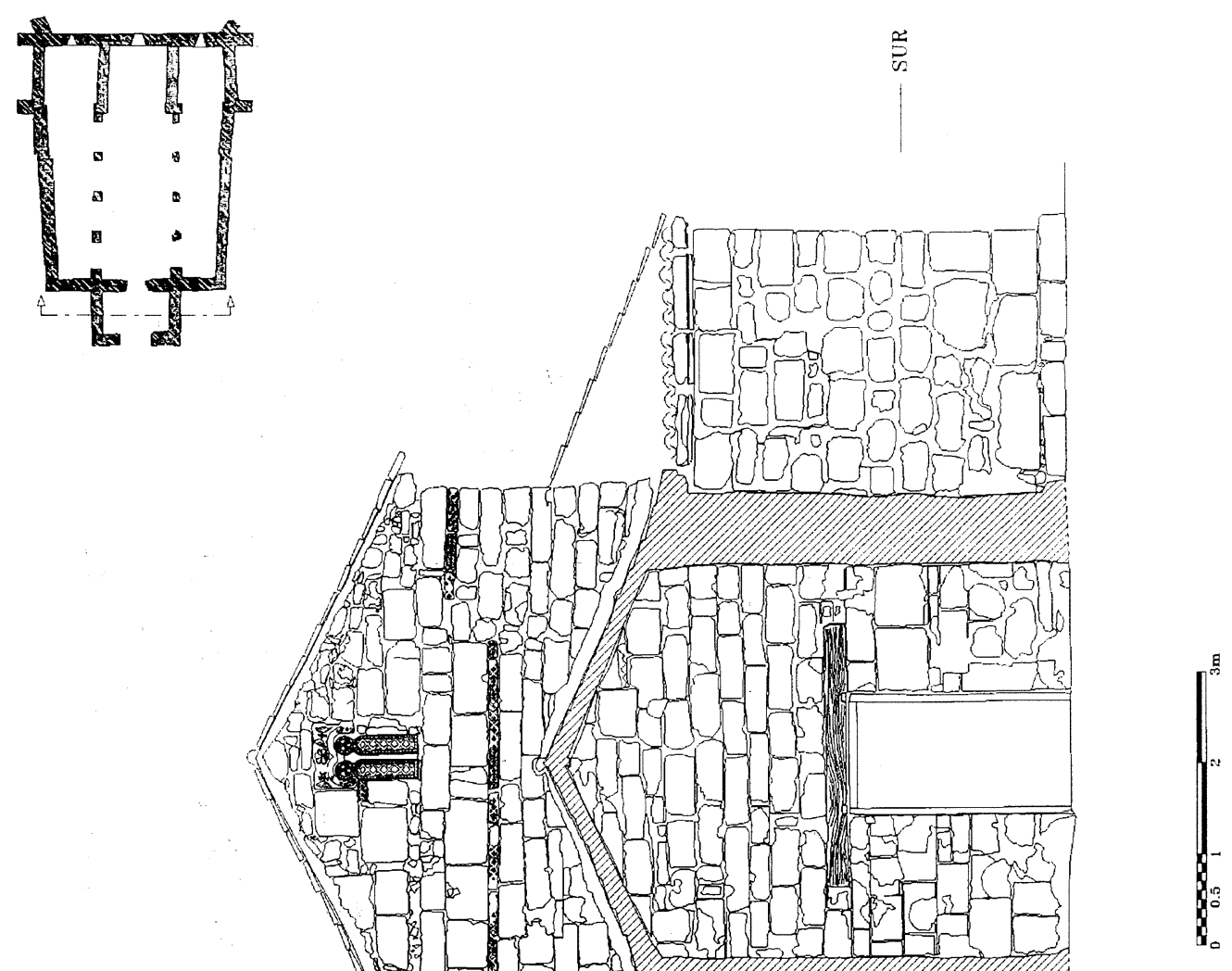


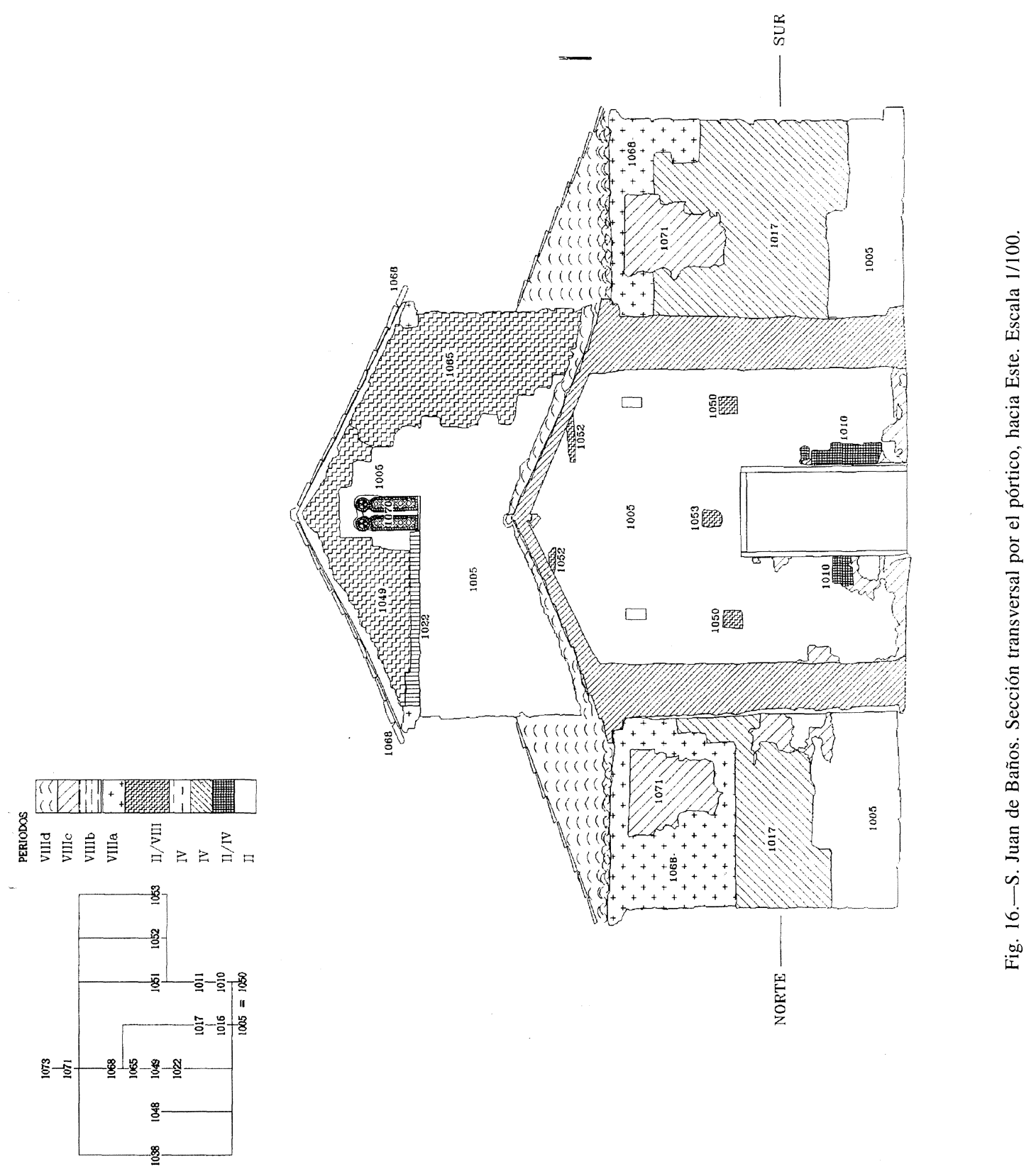



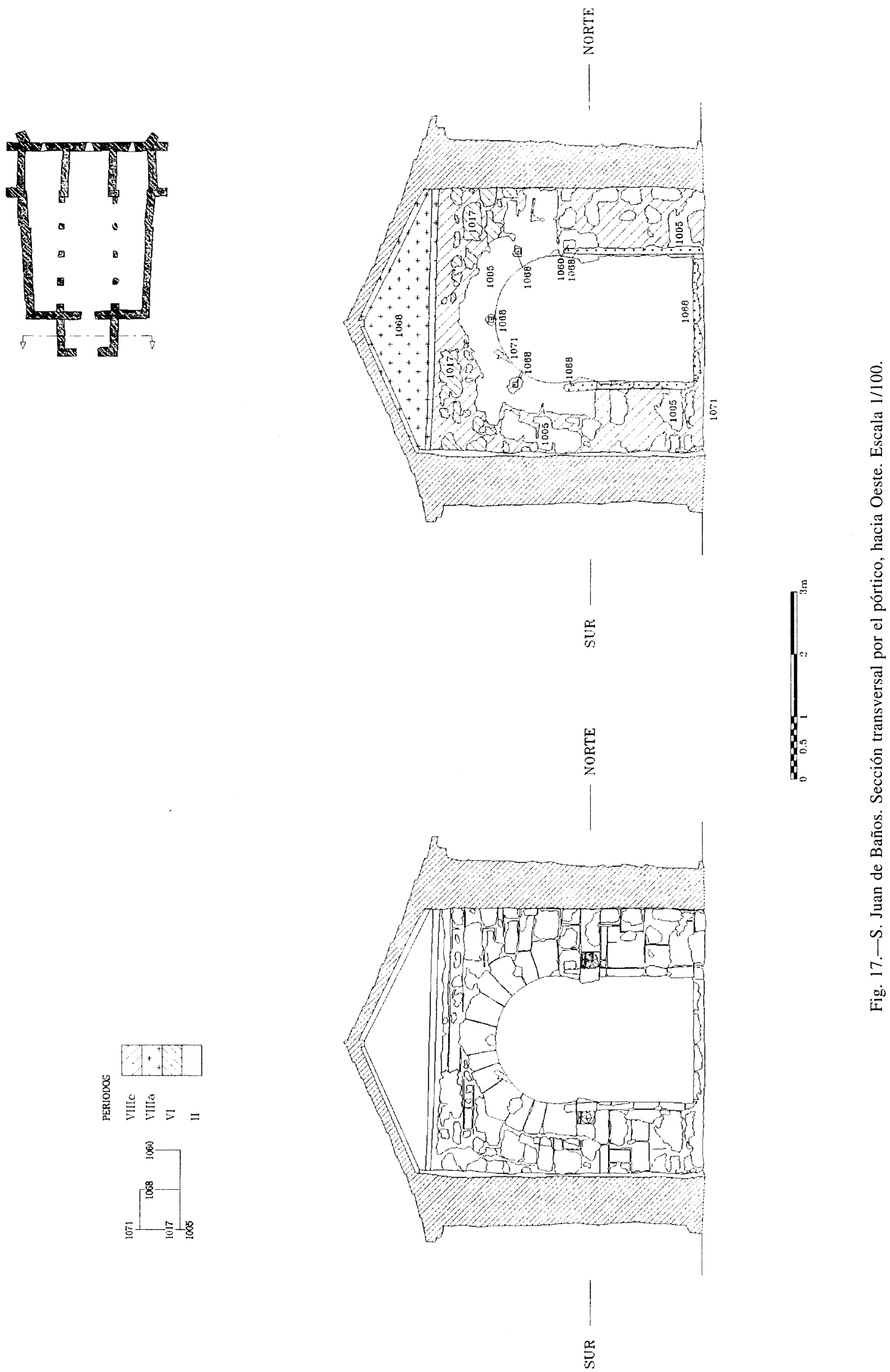
Por ello parece que deben atribuirse a una utilización previa de las piezas (sillares o ya dovelas) en que se tallaron. Algo parecido ocurre con pequeños huecos de forma rectangular y circular existentes en dos sillares a $\mathrm{O}$. y cuatro a $\mathrm{N}$. de los paramentos exteriores del pórtico (fig. 5-6). Su distinta forma, en algún caso descentrado respecto al sillar, hace suponer que son huellas de sillares previos ${ }^{4}$.

A estos indicios se deben añadir otros. En los cimientos de las arcadas apareció una inscripción funeraria en 1898 (Rodríguez y Simón: 17, n. 2). En seguida nos referiremos a otros indicios de posible reutilización de sillares en el aparejo primitivo. Columnas y frisos decorativos indican también su reutilización de otro edificio por lo cual hubieron de relabrarse. A su vez, una de las placas de cancel descubierta en 1963 reutiliza una inscripción de la que resta una hedera en su reverso (fig. 20).

Período II. Restos conservados del edificio primitivo (A 1002-5 y 1050)

La distribución de los restos primitivos en la planta, según nuestra lectura, es básicamente similar a la aceptada desde la propuesta de Aníbal y Agapito (1902 ayb, nuestra fig. 1,1 a 3). Esto es, el ábside central, los muros proximales de los ábsides laterales, los arranques de los muros occidentales de los anteábsides, las columnas de las arcadas, el testero con sus esquinas que avanzan por los muros laterales y el porche. Sin embargo no dejan de existir diferencias, sobre todo respecto a los ábsides laterales y la comprensión de los muros laterales del aula, ignorando los pocos sillares que quedan de la obra primitiva en ellos. Sólo la cara externa de estos pocos sillares se alínea con la cara externa de los muros proximales de los ábsides laterales, y no con el grueso de los muros. Nadie que sepamos se ha referido a este hecho que es el que va a determinar la oblicuidad que definitivamente toma la restauración de los muros laterales del aula y el que nos puede orientar sobre la reconstrucción de la volumetría de los anteábsides.

Lógicamente son mayores las diferencias observadas en los alzados. El ábside central se conserva prácticamente entero, con la forma aproximada de su frontón y, quizás las huellas para encajar sus canceles si no pertenecieron estas huellas a una etapa posterior (A 1021, fig. 9-10) y los muros proximales de los ábsides laterales hasta la altura del alero.

${ }^{4}$ Agapito 1902a: 32 n. 2 se refiere a «muchos signos distribuidos sin orden ni concierto» en los sillares, que supone de canteros. No sabemos exactamente a qué se refiere.
Del meridional se conserva en la primera hilada su testero hasta la jamba de su puerta con un retalle en su esquina exterior que serviría para encajar un cancel o de mocheta para la hoja que la cerrara (A 1020, fig. 4 y 14); en el aula, prácticamente enteros el frente oriental, a falta de su frontón, y la arcada S. y su muro, mientras que el muro de la arcada S. se ha perdido prácticamente desde los umbrales de sus ventanas, así como su esquina con el muro de testero, muy perdido también en sus laterales como les pasa a los muros del pórtico, cuya altura conservada oscila entre un metro y la del arco de acceso.

Como ya dijimos, Palol llegó a preguntarse si el edificio se componía de dos o tres etapas, una el ábside central, otra el aula con el pórtico y otra los ábsides laterales. Al realizar nuestra lectura, inducidos por los mismos argumentos, partimos de la misma posibilidad, por lo que hasta en la distribución de actividades mantuvimos las divisiones entre estas partes. Con una primera lectura parece que las arcadas están adosadas a la cabecera, rompiendo la arquivolta decorada en los dos lados. De ser así podría pensarse en la verosimilitud de las propuestas de Cossio y Caveda citadas, que las arcadas fueran construcciones de fecha posterior ${ }^{5}$. Sin embargo, las roturas de las arquivoltas coinciden con sendos huecos, quizás mejor sendos grupos de huecos (A 1037 y 1043), que son a los que se deben achacar sus roturas y que no sepamos en realidad cómo remataban, pues por su causa se arrancarían las piezas más inferiores de la arquivolta. También nos hemos planteado si existía una interfaz entre los muros de las arcadas y el frente encima de la embocadura del ábside. Pero allí, pese a las dudas que en una primera impresión dan las grietas provocadas por la apertura de la bóveda, nada se observa. La inscripción está colocada en su lugar primitivo a la vez que los sillares del testero en que se incluye y a la vez que las esquinas y los muros de las dos arcadas (con la salvedad de la mitad superior del S.). Creemos que la misma unidad que Palol certificó en los cimientos entre la cabecera y el pórtico, se certifica a nivel de estos muros en altura, tanto sobre el ábside como en el testero $\mathrm{O}$.

Un problema diferente es el de los ábsides laterales. Palol (1988: 23) quiso señalar en ellos otra etapa por las diferencias de estilo que observaba entre su decoración y la del ábside principal. Cómo sus restos hoy son totalmente independientes de los del resto de la iglesia no es posible conseguir una

${ }^{5}$ Simón diferencia también la perfección de los arcos del ábside y el pórtico frente a los de las arcadas, aunque no lo achaca a una diferencia cronológica. Rodríguez y Simón: 16. 
relación estratigráfica, pero las semejanzas de sus materiales y aparejos avalan su coetaneidad.

El material utilizado en la sillería es caliza fosilífera (al parecer procedente de los términos de Dueñas, Palencia, y Valoria, Valladolid, según informa Salas a Fita 1902: 495 n. 1). Pero a simple vista se distinguen tres tipos distintos de piedra. Sólo en la rosca de la embocadura y la hilada de clave del ábside central la caliza es de apreciable mejor calidad, más compacta y blanca, quizás, junto a las huellas de huecos ya señalados, indicio de su reutilización. En el resto de la iglesia, la piedra es de peor calidad, degradada al exterior y presentando dos coloraciones muy diferentes, aunque parece el mismo tipo de piedra, ocre y gris.

En el interior aún es posible observar en ocasiones el modo de talla de los sillares, también similar a la de otras iglesias altomedievales, en concreto a La Nave. Los ajustes y las juntas entre ellos son perfectas, siempre que es posible observarlas dada la degradación del material y los rejuntados sucesivos de las restauraciones (Hauschild: 273-4, lám. 43, b y c).

Los cimientos se conocen por los estudios de Palol (Palol y otros: 249), bloques planos que considera pequeños, quizás porque se han fragmentado y partido, ya que pensamos que en ocasiones tienen más anchura que la de los muros, sobresaliendo por su's dos caras ${ }^{6}$. Quizás la poca resistencia de estas losas de cimiento sea una de las causas de la ruina de los muros laterales del aula. En los cimientos de las arcadas, al contrario, grandes bloques sirven de asiento de las columnas, unidos entre si por muretes que cuando los descubre Palol son irregulares quizás por haberse saqueado en parte pues recordemos que de uno de ellos procede una inscripción funeraria (Palol y otros: 255 y fig. 8 y 9, también en nuestras fig. 5-6).

Sobre los cimientos los sillares son mayores, colocados verticales en la hilada inferior, como ya hizo notar Palol (1988: 37 fig. 6-7, nuestras fig. 1, $3-7,11,13$ y 14), característica de esta iglesia, aunque puede que se rastree en otras como en La Nave (Caballero y Arce 1995: fig. 2-4); y alternando en las esquinas su dirección en hiladas consecutivas, que se desdoblan en dos en el cuerpo del paramento. Camps observó, aunque con errores, dos tipos de piedra y las diferencias de tamaño en la sillería (p. 523-4), menor no sólo en las partes altas de las arcadas y demás muros, sino también en el centro de

\footnotetext{
${ }^{6}$ Muy parecido, salvando el material de pizarra, al cimiento de grandes lajas aun in situ en el lugar primitivo de $S$. Pedro de la Nave, documentado en la excavación dirigida allí en 1997 por Caballero.
}

los paramentos. Pero suele aparecer una hilada de excepcional altura y tamaño cerrando la parte más alta de los muros (testero O., fig. 15 y arcada N., fig. 8-9). En Baños se utilizaron mechinales pasantes para sujetar los andamios, tres parejas a distintos niveles $(2.6,4$ y $5.9 \mathrm{~m}$ ) en el testero del aula (fig. 15-6); otra al nivel intermedio en el testero del ábside, antes de voltear la bóveda (fig. 3); y una fila situada al nivel más alto con huecos entre cada ventana y entre éstas y las esquinas, en la arcada $\mathrm{N}$. (fig. 9). Debemos suponer que otros desvíos de los andamios aprovecharían los vanos de puertas, arcos y ventanas. Como ya dijimos al estudiar La Nave (Caballero y Arce 1997: $269^{7}$ ), en Baños hay lo que puede parecer un excepcional uso de la madera, en el dintel de la puerta principal formado por tres vigas de madera, cuya colocación se aprovechó para situar en sus extremos los mechinales (A 1050, fig. $\left.15-6^{8}\right)$, y lo que parece con mucha probabilidad como un tirante o durmiente, a la altura del umbral del ajimez del testero $\mathrm{O}$ del aula (fig. 16), al margen de la armadura de su cubierta.

Los sillares parece que en su mayoría son pasantes de una a otra cara, al menos hasta los dos tercios de la altura de los muros. Las hiladas muestran el cuidado con que se han igualado sus asientos de lado a lado del muro, moviéndose en ocasiones la longitud de los sillares único indicio de que no todos ellos son pasantes. Es característica la inclinación y ondulación de las hiladas, la presencia de algunos pequeños tacos o calzos, los codos muy acusados, sobre todo en el exterior del ábside, y la excesiva desproporción entre longitud y altura de algunos sillares. Estas características son corrientes en otros edificios alto medievales. Por ejemplo, en Santa María de Melque (Toledo), cuya sillería es seguro que procede de cantera, las hiladas onduladas y la presencia de codos, aunque son excepcionales los exagerados (Caballero y Latorre: 705-10, pl. 26-7 y 32-3); o en S. Pedro de Arlanza (Burgos) la sillería reutilizada con mechinales (Caballero y otros 1991/92: 151-2). El testero del ábside de Baños (fig. 3) recuerda el de Sta. Comba de Bande (Orense. Hauschild 1972: fig. 5) que justamente por los codos exagerados y la estrechez y longitud de sus sillares se consideró construido con material reutilizado (Caballero y Latorre: 706; Caballero 1991: 80 y 93). Nos podemos preguntar si la reutili-

\footnotetext{
${ }^{7}$ Con paralelos a los que hay que añadir el olvidado de $\mathrm{S}$. Miguel de Escalada, una puerta similar a la de Baños, con descargadero de madera.

8 Aníbal creyó que la puerta principal era en realidad una ventana por las huellas que descubrió en el dintel de madera, lo que fue aceptado por el propio Agapito 1902: 28 y 30 y Navarro: 20 .
} 
zación puede ser lo que asemeja ambos testeros, siempre a favor de la mejor técnica de Baños. Pero también es cierto que el alto número de acusados codos en Baños sólo se da en este testero, lo que abona por su excepcionalidad, debido a una junta de obra o a la presencia de la ventana.

Los tres ábsides estaban abovedados, con bóvedas menores en los laterales, como se ha podido comprobar con nuestra documentación (fig. 13), las tres peraltadas, tendiendo a la herradura. Como ya observaron Gómez Moreno (124) y Palol, la embocadura de la bóveda del ábside central determina directamente su arco de triunfo (que Palol 1988: 29 definía como paleocristiano; igual ocurre en El Trampal, a pesar de que las semicolumnas adosadas pretendan otra sensación). Las arcadas son de cuatro arcos apoyados sobre columnas cuyos materiales reaprovechados obligan a una altura variable de su imposta. Los arcos occidentales, que arrancan de pilastras en vez de columnas, curiosamente ofrecen curva descentrada, adoptando una forma que recuerda la de un arco por tranquil, o rampante, con arranques a distinta altura, aunque esta característica sólo ocurre de hecho en el arco N., donde puede existir un desnivel de $15 \mathrm{~cm}$ entre los dos arranques, pero no en el S. Otra diferencia en estos dos arcos es una pieza más de las que los componen en el lado E. que en el O. Esta irregularidad formal, tan similar en los dos arcos, no se relaciona de ninguna manera con alguna interfaz o reforma en sus paramentos.

Sobre las arcadas y los muros laterales la cubierta del aula hubo de ser de madera, sin que nada haga pensar en una cubierta abovedada. Los muros de las arquerías, por su lado exterior y en las enjutas de los arcos, presentan unos huecos (aprox. 30 $\times 30 \mathrm{~cm}$ ) para recibir los tirantes de la cubierta. En total son cinco, tres entre los cuatro arcos y dos en los extremos, cuya línea de base se sitúa entre 20 y $30 \mathrm{~cm}$ por debajo de la de las claves de los arcos. Todavía en el hueco más occidental del lado S. se conserva la testa de la viga encastrada. En la nave $\mathrm{S}$. queda también el hueco de un durmiente o estribo empotrado (A 1058, pl. 9 y 12) que lógicamente debe ser el de la cubierta primitiva. Es posible que también quede al N., pero de ser así, está tapado por el enjarje de la actual cubierta.

Se conservan tres tipos de ventanas. La del ábside tiene derrame al interior, imposta que la decora por las caras y su interior y arco de herradura adovelado tanto por dentro como por fuera (fig. 3 y 13). Es de suponer que los ábsides laterales tendrían ventanas de forma y decoración similares a las que pertenecerían impostas que se encuentran reutilizadas (fig. 19). Puede dar la impresión de que las ven- tanas de las arcadas son iguales, pero en realidad mezclan dos modelos bien diferentes, monolíticas al exterior, donde hace de imposta el friso exterior, y adoveladas al interior, sin imposta y con el arranque del arco ligeramente retraído sobre la línea de jamba (fig. 4, 6, 9 y 10). Su forma exterior tiene abundantes paralelos en la arquitectura altomedieval, especialmente con las ventanas dobles mal denominadas ajimeces. El tercer tipo es el ajimez, o sea la ventana monolítica de doble vano, existente en el testero $\mathrm{O}$. del aula, con columnilla de parteluz, no derramada, y restaurada por Aníbal (Agapito 1902a: 31 n. 1; fig. 15-6).

Durante los trabajos de Aníbal se recogieron fragmentos de celosías, una de las cuales, según el testimonio de Agapito (1902a: 32 n. 1 y 1903: 157) se reconstruyó y colocó. Las demás se pusieron nuevas, pero no tenemos seguridad, sin haberlas observado de cerca, de que la original se conserve (a pesar de la fotografía de Schlunk y Hauschild: lám. 107a, $2^{a}$ ventana del N.).

Períodos III y IV. Intervenciones medievales (A 1006/11 y 1023). Ruina y refacción de los muros laterales del aula. Las capillas laterales góticas.

En época medieval se cerraron los espacios intermedios entre los ábsides construyendo una cabecera de cinco habitaciones. Este cierre ocurrió en dos etapas diferentes (corresponden a las A 1007 y 1011, fig. 3, 7, 8 y 11-3), la segunda de las cuales es gótica y a la cual pertenece la cubierta de bóveda de nervios, sus ventanas y los contrafuertes de esquina de los ábsides intermedios sino se hicieron al derruir los ábsides laterales a inicios del s. XVIII. Al construirlas se cortaron los muros que cerraban los espacios intermedios (cuyo cimiento Palol buscó sin encontrar, Palol y otros: 246 y 250), rehaciendo los cortes con arcos a modo de embocadura. Dada la irregularidad del trazado primitivo, la capilla $S$. es más estrecha y apuntada que la N. Probablemente (como veremos al analizar la forma primitiva del edificio, aunque de ello no queda indicio) también se debieron cortar los muros de las naves laterales allí donde coincidían con los de los anteábsides, abriendo arcos donde hubo de haber puertas, creando un espacio a modo de crucero. En 1601 el obispo Sandoval describió esta cabecera de cinco tramos que tiene cinco capillas por frente, a la vez que el artesonado que cubría toda la iglesia, quizás mudejar y coetáneo a las capillas intermedias, decorado con escudos con medias lunas blancas en campo rojo y azul y orla colorada con lises y hojas de higuera (Quadrado: 333 n. 2). 
Es lógico pensar que estas reformas dieran lugar a la del resto de los muros laterales del aula, también ocurrida en dos momentos. Quizás la voluntad de ampliar la cabecera fuera unida a la solución de problemas previos aparecidos en las cubiertas de las naves laterales y los anteábsides. Fuera así o no, en época medieval los muros exteriores de las naves laterales se hundieron, rehaciéndose al menos en dos ocasiones y terminando por desaparecer hasta sus cimientos. Las únicas referencias sobre sus refacciones nos la da el que lo poco restante de la más antigua conservada al N. (A 1006, 1008, 1023, fig. 6) sobremonta un sarcófago que Palol considera del s. XII (1964: 22, lám. IV-VI; 1988: 22 plano) y la oblicuidad de ambas (aunque la del S., A 1017, es posterior, etapa VI) respecto al eje de la iglesia, lo que sólo se puede explicar por la desalineación que en la obra primitiva presentaban los muros laterales del aula respecto de sus fronteros del ábside correspondiente. Ello obliga a pensar que la primera vez que se rehicieron se desviaron para que llegaran a tocar el extremo de sus ábsides laterales pues, de otro modo, no se explica la razón de su inclinación.

Como la ruina de los muros laterales del aula hubo de estar en relación con la de los muros de los anteábsides, hemos de suponer también que los huecos para una cubierta situados por encima de las ventanas del lado N. y que ocupan el ancho de su anteábside (A 1047, fig. 6) tuvieron que pertenecer a un arreglo de la cubierta primitiva, que se ha de considerar medieval aunque en el diagrama, por la relación entre elementos, ocupe un tiempo mayor.

\section{Periodos V a VII. Degradación del monumento e intervenciones modernas}

Los datos documentales aportados por Agapito (1903-4) indican con claridad la suerte de la iglesia desde fines del s. XVI y explican, como bien dice este autor, que entonces el monumento entró en un paulatino proceso de degradación, agravado a partir de la creación de la cercana parroquia de S. Martín (anterior a 1559). Con los esfuerzos que la comunidad hizo por mantener la iglesia (especialmente en 1589 y 1699) pudo irse manteniendo pero no se evitó que fuera perdiendo gran parte de sus caracteres. La humildad de las intervenciones impide datarlas estilísticamente. No se puede obtener una secuencia donde todas las actividades se relacionen entre sí y tampoco es posible relacionarlas exactamente con los datos documentales, de los que no conocemos más que los de los siglos xvı y xvII. Por ello sólo describimos las actividades más importantes, limi- tándonos a reseñar, cuando es posible, sus aparentes relaciones con los datos de las fuentes (anexo 1).

- No hay referencia sobre la habitación adosada al E. del ábside central, documentada por la lectura estratigráfica (A 1066, fig. 3), ni con la restauración de mediados del XIX, con la que quizás se desmontara. Sólo es dudosa la de 1588, que de la parte de afuera tras de la capilla cierren una quiebra.

- Delante de la embocadura del ábside central (fig. 9-10) debieron existir trabes en momentos distintos, incluso primitivo, que recuerdan las documentadas en La Nave y Melque (Caballero y Arce 1997: 255). Dentro del ábside, quizás se puedan poner en relación con la construcción de las capillas góticas las pinturas con casetones y florones (A 1033), huellas de uno o varios posibles retablos (A 1028 a 1032) y una reja en la entrada (A 1036).

- Restos de tres enlucidos sucesivos efectuados previamente al primer cierre del paso a los anteábsides (A 1012-4, fig. 5 y 10). En los documentos se citan varios enlucidos y rehinchados en el S. XVI.

- El cierre de los pasos a los anteábsides (A 1015, fig. 2, 4, 6-7, 12 y 14), como ya dijimos, quizás no fue el primero efectuado y es muy probable que sea de fecha muy moderna, frente a la opinión de Palol (1964: 5-6 y 22) que considera debió hacerse pronto. El mandato recogido de que en 1588 se zierren las dos capillas colaterales que exceden de las tres nabes de suerte que la de la parte de la Epistola se pueda servir de sacristia y la otra para tener cosas dejando puertas para entrar y salir y que se cierren desde el suelo hasta el rrecibo del arco... como un tabique de yeso, no data el primer cierre conservado dado que al año siguiente se sobreseyó. Podría pensarse que esta orden se refiera a otro cierre, por ejemplo en la embocadura de los propios ábsides, pero el tamaño de la entrada a los ábsides, apenas de metro o metro y medio (Agapito 1902a: $30 \mathrm{pl}$.), hace suponer que no tendría arco sino dintel y que se cerraría mejor con una puerta sin necesidad de tabique cuyo lugar lógico sería en el acceso desde el aula. Por lo tanto el cierre debe fecharse después de 1589 , quizás no mucho después, aunque ya en el siglo XVII.

- Restauraciones de los muros exteriores de las naves laterales (A 1017 y 1019, fig. 4, 6-7 y 12). Las restauraciones de estos muros que sobremontan también el cierre del crucero gótico han de ser obligadamente más modernos, del s. XVII o posterior, y, por fuerza, anteriores a la restauración de mediados del s. XIX. Las citas que tenemos de los s. XVI y XVII hacen continuas referencias al deterioro de los mu- 
ros de la iglesia, abiertos, agujereados y presionados por las tierras sobreelevadas en el exterior (quizás a lo que contribuye no sólo la necrópolis septentrional, sino también sucesivas ruinas del edificio), recalces y reparaciones de los muros (1565 muro del cierzo, 1588, 1589, 1699), pero no es posible ajustar nada más.

- No se pueden relacionar por hoy las huellas de varias cubiertas en las naves laterales (A 1054 y 1057).

- Derribo de los ábsides laterales (A 1018, 1025, fig. 4, 6 y 14). Las fuentes reiteran su mala situación probablemente resultado de la tendencia a abrirse de sus bóvedas (como denuncian aún las grietas en el ábside central) y de los empujes desiguales de las capillas intermedias cargadas sobre sus muros proximales, que también señalan movimientos de dirección E-O. Como bien razona Agapito su ruina definitiva debió tener lugar en 1702. La colecta efectuada para su reparación debió terminar en su más fácil derribo y aprovechamiento de la piedra para construir la torre de la parroquia. Ya en 1610 se habían sacado de S. Juan 24 carros de piedra que pudieron proceder de las ruinas que sobreelevaban el terreno a su alrededor, pero que también podían proceder de demoliciones parciales de ellas y el crucero medieval.

- La refacción del ángulo SO. del aula (A 1065 , fig. 4-5, 12 y 15) puede corresponder a la orden de 1575 de que se repare la esquina de cantería de la iglesia. rencia.

- Coro trasero (A 1042). Sin ninguna refe-

- Los muros del porche están fuertemente rehechos por encima del arco (A 1016 y quizás 1017, fig. 5). Se documenta la restauración de un agujero encima de la puerta de entrada en 1589 , quizás cuando se colocara allí el fragmento de placa decorada que creemos fragmento de ajimez. De ser así, ofrecería una fecha cruzada para la reforma de la cubierta de la cabecera y el desmoche del frontón oriental del aula.

- Puertas antiguas del porche (A 1038 y 1068, fig. 5 y 17). La exterior documentada en fotos anteriores a la intervención de Aníbal (Rollán: lám. 10).

- Según las fuentes, S. Juan tuvo una torre con función de campanario (1587 y 1588). Los únicos restos que podrían ponerse en su relación son las rozas A 1048 y 1064 (fig. 4 y 6), simétricas, que pudieron pertenecer a los suelos o la escalera de madera de un camaranchón sobreelevado sobre los muros de la iglesia. Pero no es segura esta posibilidad, dado el término empleado y la contradición con la noticia reiterada de que la actual espadaña, sobre la fachada del pórtico, es imitación de la antigua, a no ser que aquella estuviera sobre el testero de la nave central.

\section{Período VIII. Restauraciones contemporáneas}

- Qué se puede documentar de la restauración de mediados del s. XIX. La «anastilosis» del muro de la arcada S. (A 1039, 1063, 1068, 1069 y 1072?)

Como dijimos, las noticias de esta criticada restauración son muy genéricas. Según Simón se efectuó en 1865 y le atribuye la espadaña, la elevación de las naves laterales, la cornisa dórica y la cubierta (Rodríguez y Simón: 3-4). No cabe duda de esta restauración «neoclásica», efectuada con sillería tallada en dos tipos de piedra que se reutiliza de un edificio distinto, como advierten algunas letras de inscripciones, asentada con la ayuda de pequeñas cuñas de madera que aún se conservan y rematando todo el edificio con la moldura dórica. No sólo afectó a los muros laterales y de testero de las naves laterales, también al contrafuerte SO. (y su paralelo del lado N. según testimonio de Rada 1872: 568, aunque su apariencia actual sea de Arenillas), a la esquina SO. del pórtico (anterior a Aníbal, Quadrado 1885: 332 fig.) y a la espadaña, confirmando el reiterado testimonio. En los testeros de las naves laterales se abrieron sendas ventanas y otras dos en el muro lateral de la S. , quizás restos de otras anteriores dada la rareza de ser cuadradas, con platabanda al interior y arcuadas al exterior (fig. 4 y 12); sólo la limpieza de los enfoscados podría aclarar este extremo.

Si hacemos caso del juicio indirecto de Camps y Palol y de lo que documentamos en la lectura de paramentos, habría que atribuirle además la restitución de las partes altas de la nave central. Nada impide dar como primitivo el muro $\mathrm{N}$. de la nave central, hasta su moldura, en su integridad (fig. 8-9). Su aparejo, la presencia de mechinales, igual y a la misma altura que en otras partes del edificio, y, como veremos, la modulación redundan en la conclusión de la estratigrafía mural. No ocurre así en el muro S. (fig. 10-11). Por su interior se observan con claridad varios hechos: la ausencia de mechinales; la inclinación hacia el interior de la iglesia de la parte baja del muro que incluye los arcos y aproximadamente hasta los umbrales de la ventana, mientras que el muro por encima de esta interfaz (señalada en la fig. 10) sube vertical; la aparente diferencia de tratamiento de las caras de los sillares, 
más cuidada en la zona inferior y más rugosa en la refacción superior; el aparejo distinto especialmente entre la $2^{\mathrm{a}}$ y $3^{\mathrm{a}}$ ventana, y en parte de la $3^{\mathrm{a}}$ hacia el O. (desde el ábside); y la mayor abundancia de enfoscado de lo normal en todo el muro, con los sillares dibujados sobre él. Por fuera es más difícil diferenciar la restauración, pero se nota también por las esquinas más redondeadas de los sillares, sus roturas, espacios abiertos entre sus juntas (lo que se observa gracias a la pérdida de enfoscado entre ellos) y la irregularidad del friso decorado.

Parece indudable, por lo tanto, que existe una fuerte restauración en lo alto del muro de la arcada S., tanto al exterior como al interior, desde la esquina E. hasta la $3^{\mathrm{a}}$ ventana $\mathrm{y}$, por el interior, entre las $1^{\mathrm{a}}$ y $4^{\mathrm{a}}$ ventanas. Pero no son nada claras, para el sistema de observación que hemos seguido, sus características. Existen, al menos, dos actividades que no sabemos si pertenecen a etapas de obra o a restauraciones. Es muy clara la interior entre las ventanas $2^{\text {a }}$ y $3^{\text {a }}$, diferenciada por el tamaño menor de su sillarejo. Esta observación no se puede hacer al exterior, aunque también allí se observa una restauración hacia el E., por debajo de la moldura. Lo demás, siendo evidente su restauración, se ha realizado con los mismos materiales de la construcción primitiva, dando la razón a las observaciones citadas de Camps y Palol: se trataría de una verdadera «anastilosis» o restitución. Nosotros hemos reservado por ello dos actividades, la A 1039 para lo realizado con sillarejo y la A 1063 con los sillares primitivos. Pero esta diferencia no presupone cómo se desarrolló la restauración, si se trató de dos restauraciones distintas o de una sola. Su perfección y la evidencia de que el muro se desmontó para devolverle su verticalidad obligan a atribuirlo a una sola restauración culta. No parece que ésta pueda ser la de Aníbal, quien asegura que efectuó obras solo de limpieza y conservación (Agapito 1902a: 16), luego ha de ser la controvertida anterior $\mathrm{y}$, para nosotros, anónima.

Aún hay que añadir a todo lo dicho la restauración de la columna $3^{a}$ de esta misma arcada $S$. (fig. 10-1). Se abrieron huecos en los laterales del salmer y la primera dovela para apear la obra; se desmontó la columna cortando la parte alta de su fuste para sanearlo, dado que debía estar agrietado o desgastado; y se volvió a montar todo, el fuste sobre un tambor nuevo inferior, quizás invirtiéndolo y retallando su extremo superior para ajustarlo al diámetro menor del capitel. Otra restauración semejante se efectuó en la jamba N. del arco del pórtico (A 1060, fig. 5 y 17), de la que se conservan los huecos abiertos en el salmer para apearlo, quizás para sanear los si- llares que lo sustentaban, pero sin sustituirlos, o sea realizando de nuevo una «anastilosis». Finalmente la colocación de una cancela por la parte interior del arco del pórtico. Creemos lo más plausible que estas obras sean de la restauración de mediados del s. XIX, y no las creemos posibles ni de Aníbal, por lo ya dicho, ni tampoco de las actuaciones de los años -50 en adelante pues su importancia hubiera obligado a oficializarlas, sin que exista constancia de ellas ni en los expedientes del Ministerio ni en la memoria de Palol.

Es probable que con esta restauración se desmontara la habitación adosada al exterior del ábside central, de la que no hemos encontrado ninguna referencia, y (a pesar de aparentar ser una actuación contraria al espíritu de todo lo que hasta aquí le hemos atribuido) se cerrara el ábside para utilizarlo como sacristía, colocando delante un retablo de otro lugar, y se blanqueara por dentro todo el edificio (Agapito 1902: 15 y 34 lám. ).

- La restauración de Aníbal Álvarez. Años 18981902. (A 1070)

Supuesto todo lo que acabamos de decir de una restauración anterior a la de Aníbal, apenas le queda a éste más mérito que haber renovado la cubierta; limpiar todo el blanqueo interior (enfoscando a cambio, Rodríguez y Simón: 2); abrir el ábside y los huecos para que se vean los paramentos labrados de los muros al fondo de las capillas laterales actuales, en las esquinas y en sus entradas también distales, quizás antecedente de los abiertos para ver los enfoscados góticos (Agapito 1902: 27-8 ); quizás rematar el frontón del testero de la nave y el contrafuerte SO.; arreglar el ajimez y colocar las celosías, el altar y una verja todo alrededor del monumento para su defensa.

- Las restauraciones de A. Arenillas, I. Sanz Fernández, F. Íñiguez y L. Cervera. Años 1950-82 (A 1071) y las últimas intervenciones (A 1073)

A excepción de lo ya citado, no siempre es posible saber a quién atribuir cada intervención. Especialmente agresiva es la actuación de reposición de abundantes sillares en paramentos, aprovechándolos del murete de la verja exterior que ahora se desmonta, en ocasiones sustituyendo restauraciones de ladrillo, en otras sillares descompuestos como los del frente de los ábsides, debido a las humedades de las tierras acumuladas y retiradas con las primeras res- 
tauraciones, o los de la esquina SO. y la jamba $\mathrm{S}$. del arco del pórtico, y, en otras, tapando huecos de obras antiguas como la del coro en las arcadas. También se recalzan con hormigón los muros de las naves laterales y, sin dejar huellas visibles en la lectura de paramentos, se refuerzan las bóvedas de los ábsides, actuación típica de Arenillas cuyo resultado quizás fue contrario al que se pretendía. También puede calificarse de agresivo (reiterando la crítica efectuada sobre actuaciones semejantes anteriores) el enfoscado general, que intenta unificar el aspecto de todos los paramentos dibujando sillería allí donde es evidente que ni se conocía, como en los tabiques de las ventanas que ahora se cierran.

Los retejos han sido continuos en el edificio, pero la cubierta actual la creemos una intervención, cuya fecha exacta no conocemos, posterior al retejo de I. Sanz en 1980. También se han documentado ligeras incisiones de plomos y horizontes efectuadas por el equipo alemán que documentó la iglesia en 1994.

\section{EL PROBLEMA DE LA DECORACIÓN DEL EDIFICIO PRIMITIVO}

Como ya hemos dicho, Palol planteó la posibilidad de que los estilos decorativos que creía distinguir en el edificio correspondieran a etapas distintas de su construcción. Este recurso ha sido muy utilizado para explicar momentos constructivos distintos en nuestra arquitectura altomedieval que nosotros, por principio, no hemos creído adecuado. Así se dijo de La Nave, Quintanilla e incluso S. Miguel de Liño (Oviedo. Gómez Moreno: 128-33; Corzo: 111 y 143; Real: 67-8). Respecto a Baños, Palol creía ver diferencias, que nosotros no vemos, en la técnica a bisel del friso de cuadrifolias del ábside central frente a los de cintas de los laterales. Sin embargo sí parecen significativas las diferencias que existen entre otras piezas de Baños: entre los cimacios de las columnas, los frisos de círculos secantes, el ajimez, los fragmentos de elementos muebles descubiertos en 1963 y la barrotera llevada por Rada al Museo Arqueológico Nacional.

Analizada la decoración hemos llegado a la siguiente conclusión que exponemos en síntesis. Se distinguen dos conjuntos (fig. 18-9), uno de piezas decoradas antes de la construcción de la iglesia, al menos una parte reaprovechadas en ella, y otro de piezas talladas ex profeso para su construcción. El primer conjunto (además de por sillares, dovelas y columnas) está formado a su vez por dos grupos. Uno (grupo 1) por los cimacios de las columnas orientales y otra pieza conservada en el ábside N. , diferentes a los demás y de tipología visigoda no discutida. El otro (grupo 2) es el mayor, en el que recae la duda de su cronología (Caballero 1994-95: 112-6). Está formado por los abundantes frisos y arquivoltas con círculos secantes o cuadrifolias en los que se ha creído ver paralelos con obras omeyas, situados en el ábside central, el aula y el porche (una de cuyas piezas de arquivolta es recta). Muchas de estas piezas están recortadas por sus testas y asientos para poder recolocarlas y otras redecoradas. En el friso del ábside central se observa que se reutilizan parejas de piezas que en origen tenían una dimensión de tres codos de largo. Quizás se puedan añadir a este grupo segundo los frisos de cintas de los ábsides laterales y las arquivoltas de los arcos.

El segundo conjunto es el de las piezas decoradas para la actual iglesia. Un grupo (grupo 3A) lo forman los retalles necesarios para decorar las testas cortadas al acoplar las piezas reutilizadas a sus nuevas medidas: testas de los cimacios de las pilastras de las arcadas y del arco del pórtico, también con cuadrifolias pero de diferente dibujo y factura. El último grupo (3B) está compuesto por los cimacios de las ventanas de los ábsides, los canecillos que sostienen la inscripción, el ajimez del aula, otro posible ajimez y las piezas de canceles, y se relaciona con tipos de cronología discutida, como los de El Trampal, Melque y Lisboa, o de segura fecha post711 como el de la asturiana Liño.

Estas observaciones no consiguen datar la iglesia, ni su decoración, pero plantean una nueva explicación sobre el problema de la datación, alternativa a la consensuada, suponiendo que la decoración tiene tres procedencias distintas:

Primera: decoración reutilizada (grupo 1), de tipología visigoda consensuada. Hipotéticamente podría añadirse a ella la inscripción fechada a mediados del s. vil que, de ser así, procedería de otro edificio anterior ${ }^{9}$.

Segunda: decoración reutilizada (grupo 2), de tipología visigoda discutida, pues podría haberse efectuado por un taller de raíz omeya.

Tercera: efectuada para el edificio actual, retallando piezas del grupo anterior (grupo 3A) o tallando elementos ex novo (grupo 3B) en un taller con influencias asturianas y otras evolucionadas de los anteriores.

Tras este planteamiento describimos las características de las piezas que componen estos grupos.

\footnotetext{
${ }^{9}$ El argumento ya lo expone, para refutarlo, Simón: $A d$ mitida como es forzoso admitir su autenticidad (de la lápida) ... hay que reconocer, si se niega á la Basilica el origen visigodo, que esta lápida procede de otro templo á quien el actual ha sustituido en época incierta. Rodríguez y Simón: 15.
} 


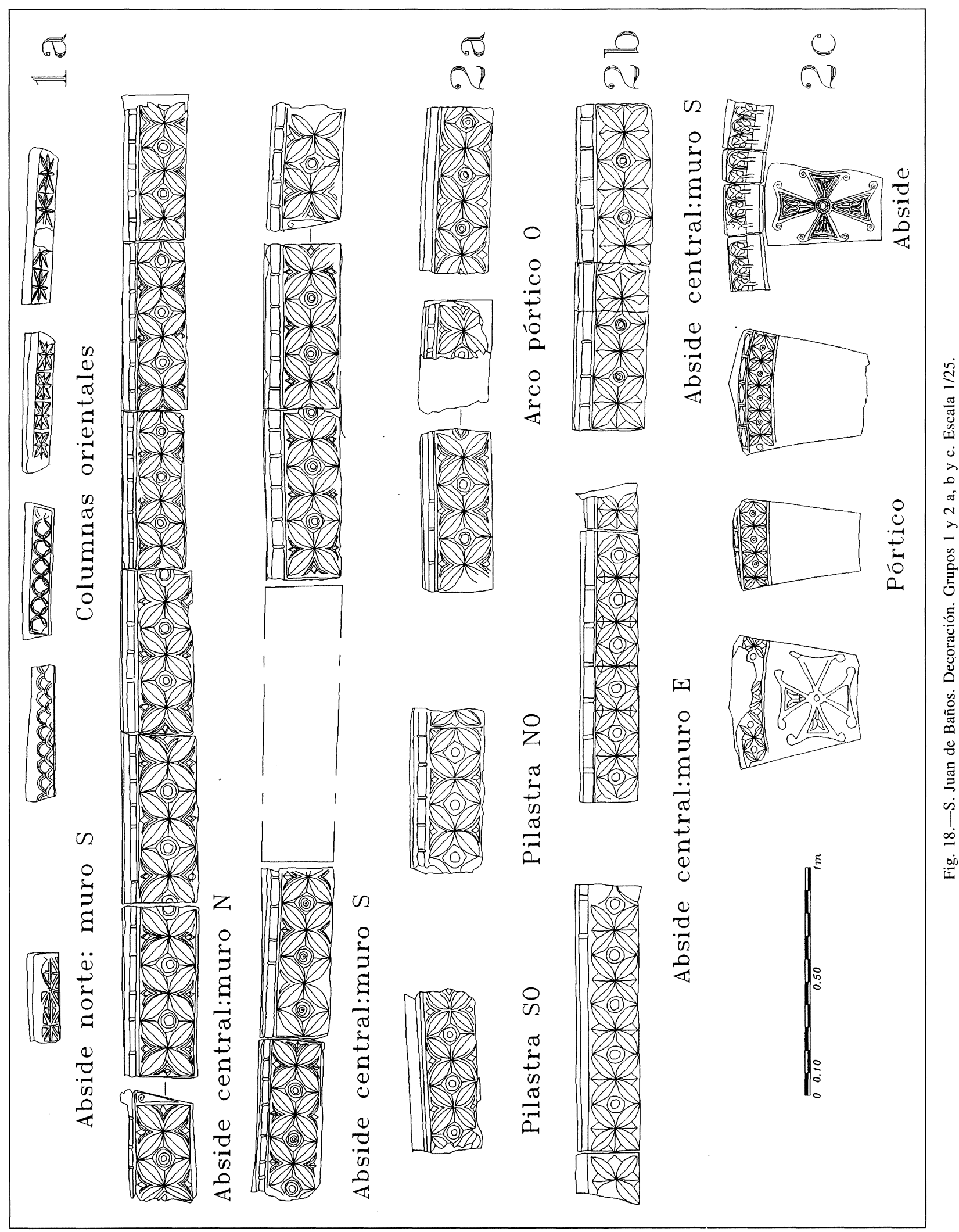




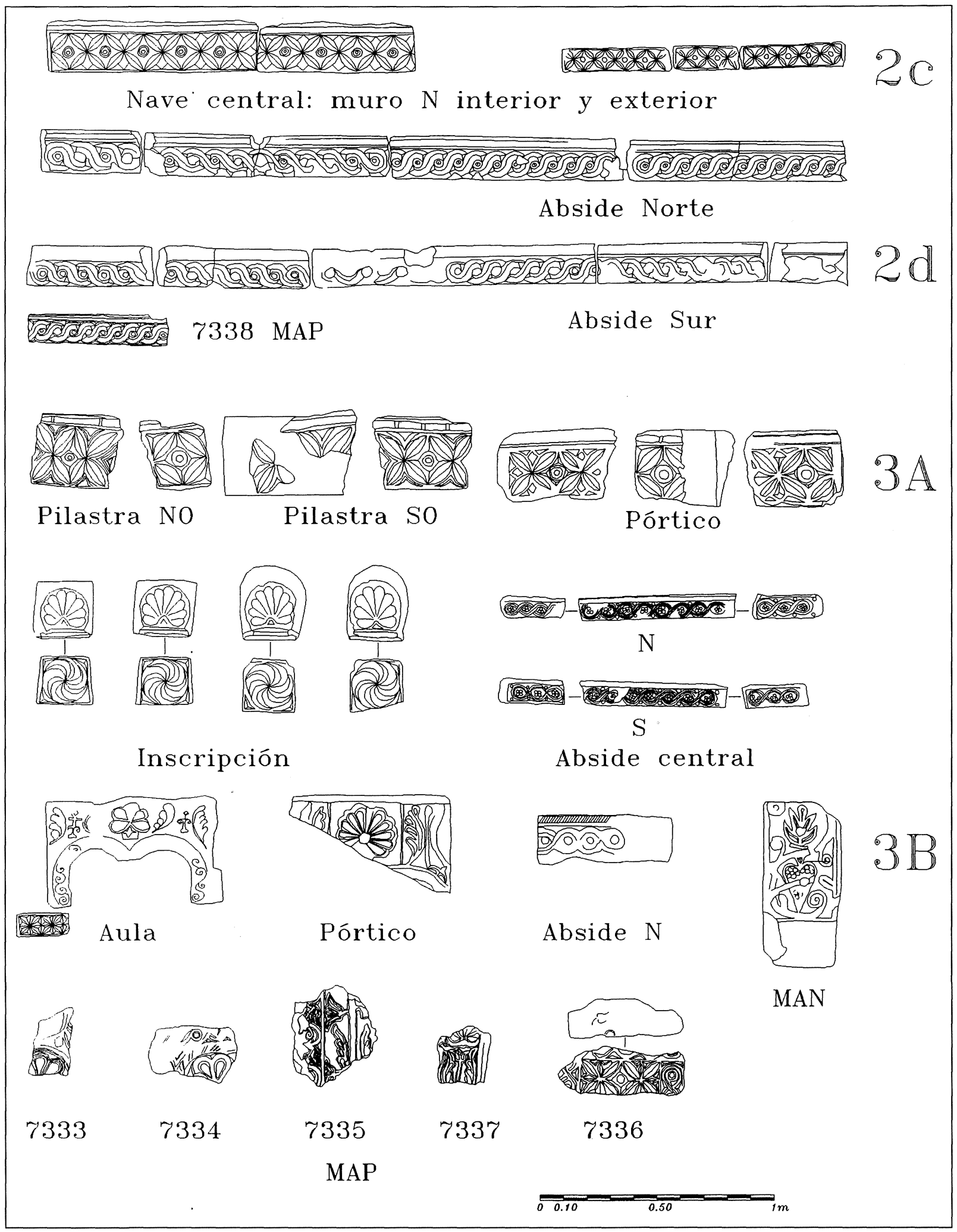

Fig. 19.-S. Juan de Baños. Decoración. Grupos 2c y 3 A y B. Escala 1/25. 
Los cimacios con imbricaciones y aspas con cruces de los capiteles vecinos a la embocadura del ábside central y otra pieza recolocada en el ábside N. a la altura de su compañera forman el primer grupo (Camps 1947: fig. 307 y 312). Estas piezas parecen estar cortadas para acomodarlas al edificio, igual que les ocurre a la pareja de capiteles adosados a la embocadura del ábside mayor. Por lo tanto este grupo incluiría piezas que es seguro que se reutilizaron o al menos se tiene cierta sospecha de ello. Como otras piezas (sillares, dovelas y columnas) y las piezas del siguiente grupo son también reutilizadas, podemos preguntarnos si todas las piezas tuvieron la misma procedencia, lo que no parece seguro dadas las diferencias de estilo de todos estos expolios.

El núcleo del segundo grupo lo forman los frisos de tamaño grande decorados con cuadrifolias o círculos secantes con botón central, flores de lis en sus intersecciones y filete con ovas y perlas, situados en los laterales del ábside central, en las pilastras de las arcadas y en el arco del pórtico (grupo $2 \mathrm{a}$, fig. 18). En estas piezas, como veremos, se pueden observar datos muy significativos sobre cómo se generó y decoró la iglesia. Dos de estas piezas, situadas a partir de la embocadura en el lado N. del ábside central (fig. 9), unen perfectamente entre sí de modo que forman un friso continuo, sin discontinuidades en su dibujo, que se inicia en el primer sillar con medio círculo cuyo hueco rellena una flor de lis y remata en el segundo con otro medio círculo también con su flor de lis. Podemos preguntarnos si la cara lateral del segundo sillar aún está decorada como lo está hoy la visible de la izquierda que actúa como imposta del arco de triunfo. Las dos piezas miden 75 y $74 \mathrm{~cm}$, unidas en su situación actual $150,5 \mathrm{~cm}$ ( 3 codos de $50,16 \mathrm{~cm}$ ). El resto de las piezas de este grupo debieron formar parejas semejantes, aunque hoy están situadas en posiciones diferentes, desconcertadas respecto a sus inicios y sus juntas centrales, y cortadas lateralmente de modo que no todas tienen sus $75 / 74 \mathrm{~cm}$ de origen sino que oscilan entre 69,5 y $73 \mathrm{~cm}$.

Lo mismo ocurre con las piezas utilizadas como impostas de las pilastras occidentales de las arcadas y del arco de ingreso al pórtico (fig. 8-11, 15 y 18). Las cuatro se han cortado quizás escasos $5 \mathrm{~cm}$ para ajustarlas al ancho requerido, sin cuidarse de que el corte coincidiera con el esquema decorativo. Posteriormente, sus laterales se decoraron por otra mano (grupo 3A), con variantes muy expresivas, las elipses que llamaron la atención de Rada y, en vez de las flores de lis de las intersecciones, dobles líneas en las pilastras y ángulos en el arco del pórtico (para el corte en la pilastra N., Palol 1988: 40; y la diferencia de temas en Schlunk y Hauschild: lám. 107c, pilastra S.).

En el ábside, una variante de este grupo la forman las piezas de su fondo y las $3^{\mathrm{a}}$ y $4^{\mathrm{a}}$, desde la embocadura, de su lateral S. que presentan ángulos, en vez de flores, en las intersecciones de los círculos y son mucho más largas, llegando a sobrepasar los 117.5 y $118 \mathrm{~cm}$ las del testero. Justamente éstas también están limpiamente cortadas por el vano de la ventana, sin respetar un final armónico de su decoración. Otras piezas del ábside, pertenecientes a una u otra variante, también están cortadas: las $4^{\mathrm{a}}$ y $6^{a}$, desde la embocadura, del lado N. y las $1^{a}$ a $3^{a}$ del lado $\mathrm{S}$. con toda claridad por su cara inferior y la que simula ser la $4^{\mathrm{a}}$ del lado $\mathrm{S}$. que en realidad está formada por dos trozos de 52,5 y $21 \mathrm{~cm}$ cuidadosamente cortados para que sus dibujos coincidan y creen la ilusión de una pieza entera.

Lo que hemos descrito es lo más evidente, que, como dijimos, no escapó a la observación de Palol. Debemos preguntarnos por ello si otras piezas de las que decoran el edificio pertenecen a este grupo reutilizado o forman conjuntos distintos. Pero estas piezas no presentan indicios tan seguros de su reutilización, por lo que para su adscripción a uno u otro grupo nos basamos también en el criterio del estilo y su técnica. A nuestro parecer, frente a la opinión de Palol, por técnica y estilo también deben pertenecer a este primer grupo los frisos grandes de los ábsides laterales (fig. 4, 6 y 19) con cintas entrelazadas, botones en los centros y el filete de ovas, pues presentan talla a bisel incluso en el fondo de las cintas y se unifican con los frisos de círculos secantes por el filete de ovas y perlas que lo remata. En cada friso conservado hay sendas piezas que invierten el sentido en que se cruzan las cintas. En el lado S. hay dos cambios mediante un bucle en forma de $\mathrm{U}$ invertida, y en el $\mathrm{N}$. otros dos mediante una onda completa de una cinta, bajo la cual semeja girar en redondo la otra cinta.

En cambio, puede considerarse indicio de reutilización (aunque sin total seguridad) el que estén cortados los motivos de círculos secantes en las uniones de las dovelas del arco del porche (Palol 1964: lám. 15) y que al menos una de ellas, la $2^{\mathrm{a}}$ a la derecha de la clave, sea un friso recto y no una arquivolta curva (fig. 5 y 19).

Los frisos menores de cuadrifolias o círculos secantes, que coronan el aula por dentro y por fuera doblando en las jambas de las ventanas, es dudoso que pertenezcan al mismo grupo por el criterio de reutilización (fig. 4-6, 9-10 y 14-5). Por una parte sus extremos y juntas no coinciden en su colocación 

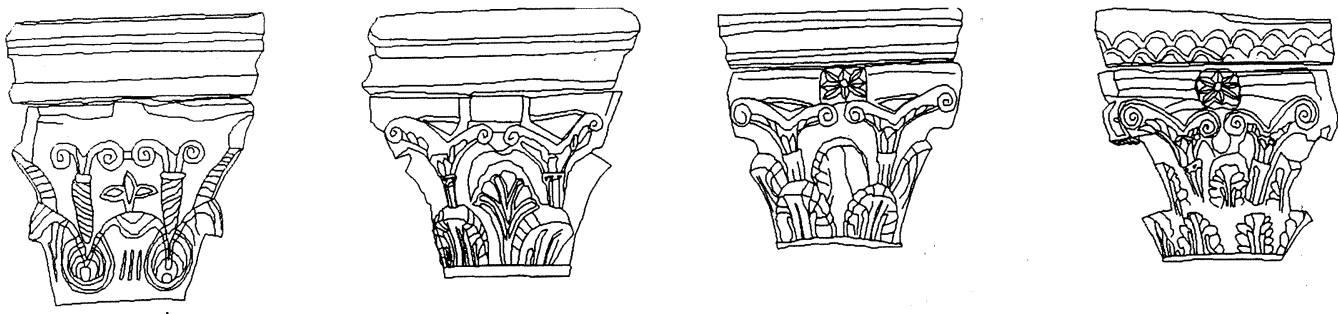

\section{ARQUERIA SUR}
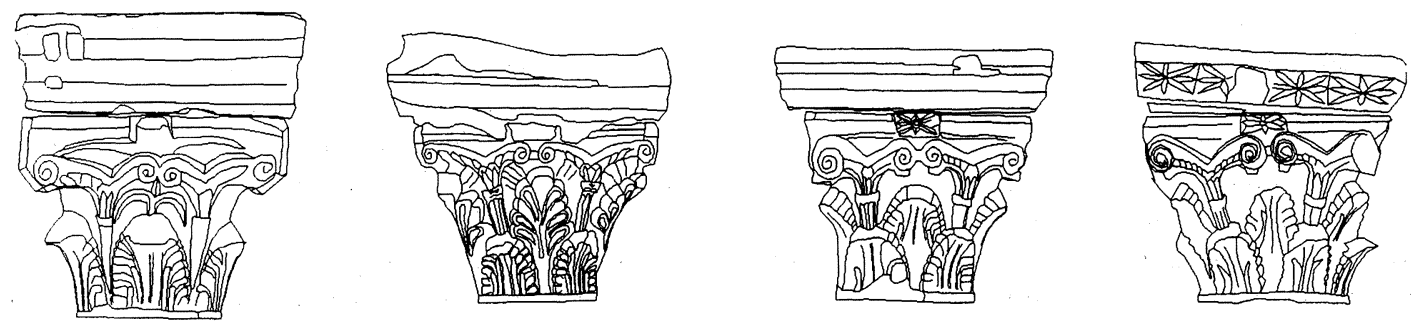

\section{ARQUERIA NORTE}

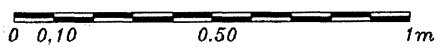

Fig. 20.-S. Juan de Baños. Capiteles. Escala 1/25.

actual, lo cual avalaría su reutilización. Pero, por otra parte, parece que las piezas tienden a un esquema de cuatro o cinco centros de círculo con botón y medio círculo en esquina con ángulo lateral, de modo que, si estuvieran bien colocadas, el friso corrido podría simular un ritmo en que alternara un aspa, resultado de la tangencia de dos ángulos, cada cuatro o cinco botones, imitación de lo que desordenadamente ocurre en los frisos grandes del ábside por la reutilización de piezas. Sólo una observación directa y detallada, con andamio, permitirá asegurar una u otra opción.

Los cortes que han sufrido las piezas de los frisos grandes de cuadrifolias, obligan a pensar en su segura reutilización. No ocurre lo mismo con el resto de piezas decoradas que por su estilo o técnica hemos unido en el mismo grupo 2, quedando dentro de lo probable si se debiera formar con ellas otro grupo intermedio o si se debieran incluir en el grupo tercero, tallado a propósito para la iglesia.

Ya nos hemos referido al grupo $3 A$, que retalló las piezas reutilizadas del grupo 2 . El grupo $3 B$ (fig. 19) lo forman las cinco piezas encontradas en las excavaciones de 1963 y la reutilizada en la enjuta del arco del pórtico, con las que Palol reconstruye tres canceles, y otra más con sogueado, reutilizada en el interior del ábside $S$. , que pudo pertenecer al tercer cancel de Palol (1964: fig. 4). A este subgrupo deben pertenecer también la barrotera de cancel conservada en el Museo Arqueológico Nacional (MAN) de Madrid, aunque àparentemente su estilo decorativo parezca diferente a los de las restantes piezas del grupo (Camps 1946: 581, fig. 321); los canecillos de la inscripción; las impostas con cintas y grupos de botones en la ventana del ábside central y en posición secundaria en la ventana del ábside N., junto a la jamba S. del ábside S. y en el mismo muro exterior; y el ajimez del aula, que parece de peor calidad quizás sólo por haberse degradado al estar a la intemperie (Arbeiter y otros: 9). Si nos fijamos en la similitud que tiene esta pieza con la reutilizada en la enjuta del arco del pórtico, deberemos considerar ésta un segundo ajimez, quizás el que estaría situado encima de la inscripción en el frontón oriental del aula. Los círculos secantes y las cintas de este tercer grupo se diferencian de la mano del segundo y se asemejan más a la que los retalló e imitó que también incluimos en este tercer grupo que engloba, por tanto, la decoración que parece específicamente efectuada para la iglesia. 
¿Qué consecuencias acarrean las observaciones efectuadas sobre la decoración? Ante todo los frisos grandes de círculos secantes no se deben asimilar a la construcción primitiva de la iglesia. Hay que aceptar que fueron realizados para otro edificio que poseía elementos constructivos decorados de tres codos de longitud y luego se reutilizaron en esta iglesia. También creemos que este dato no permite diferenciar dos momentos en su construcción. La iglesia actual ofrece una unidad constructiva evidente, incluyendo sus laterales. Pero a partir de aquí, las demás consideraciones que hagamos entran en el terreno de las conjeturas más o menos probables. No se puede asegurar qué diferencia temporal y cultural separa los tres grupos decorativos que hemos formado. Pudieron ser casi coetáneos, o pudieron pertenecer a momentos o culturas muy diferentes, siendo el segundo grupo modelo para el tercero (como propone el paradigma visigotista) o perteneciendo ambos a un estilo donde ya se refleja el aportado por los musulmanes, como nos gusta considerar a nosotros. También, pese a nuestra plausible explicación de que la inscripción de Recesvinto se corresponda y feche el primer grupo de piezas reutilizadas, no tuvo por qué ocurrir así y pudo ser coetánea al segundo o al tercer grupo; ser reutilizada pero independiente, anterior a la restante decoración de la iglesia; o que se tallara a propósito para ella.

Los paralelos estilísticos de las piezas decoradas tampoco resuelven definitivamente su adscripción cronológica mientras existan dos paradigmas explicativos no consensuados. En este sentido tiene especial interés decidir si la barrotera de cancel del MAN (fig. 19) pertenece al grupo de los canceles descubiertos por Palol. A primera vista, el desorden de su esquema hace que no lo parezca. Recuerda muy de cerca la placa de Valeránica (Burgos. Williams: 241, fig. 3, lám. 7; Caballero 1989: 115) que Noak (586-8) supone influida por el arte «mozárabe» de S. Miguel de Escalada (León) y por lo tanto posterior al s. X. La barrotera de Baños tiene un racimo en forma de gran hoja rellena con botones, sarmientos rematados en espirales, hojillas brotando del marco y una hoja palmeada que no es difícil relacionar con Valeránica y Escalada. Aunque a primera vista esta barrotera parece diferente de las placas de cancel de Baños, que hemos denominado tercer grupo, se encuentran similitudes con ella y con Valeránica en la división en estrechas fajas verticales por medio de tallos fuertemente resaltados y en la colocación inorgánica de sus elementos, ordenados en relación con los marcos más que con el campo que rellenan (placas 1 y 2 de Palol 1964: fig. 5-6). Si se consideran aceptables estas relaciones, debe plantearse la posibilidad de que, al menos con criterios tradicionales, el denominado tercer grupo decorativo sea de cronología post-visigoda.

El tema de cintas presenta algunos paralelos hasta ahora no aducidos y que pueden ser argumento a favor de una cronología tardía, postvisigoda. El friso grande con cintas de los ábsides laterales tiene uno, prácticamente similar en tamaño, talla y dibujo, en dos piezas de la sacristía y el pórtico N. de Moreruela de Tábara (Zamora) que no pasaron desapercibidos a Gómez Moreno (1919: 105 y 211; Caballero 1995: 413-4). Es evidente que en Tábara pueden encontrarse piezas de época visigoda junto a otras posteriores, pero allí es especialmente denso el foco mozárabe y numerosas las decoraciones que se pueden asimilar a una cronología tardía ${ }^{10}$. Igual ocurre con la iglesia de El Trampal, que el mismo Palol considera probablemente de época postvisigoda y cuya forma arquitectónica paraleliza con la de Baños, cuyos frisos pequeños de cintas y botones, que en las ventanas también funcionan como impostas, son prácticamente iguales a los que decoran la ventana del ábside central de Baños, y donde otros motivos, como la hoja-racimo, la hoja palmeada o los sarmientos en espiral, recuerdan el tercer grupo de Baños (Caballero y Arce 1995: 199, fig. 4-5; Caballero y otros 1991: lám. 3,e-h). Sin agotar todos los paralelos, se puede aducir cierta relación decorativa con S. Martín de Salas (Asturias), documentada en 896 y posteriormente reconstruida en 951. Una de sus ventanas ajimezadas se enmarca con una moldura de doble trenza tallada a bisel que recuerda la de los ábsides laterales de Baños a no ser por su diferencia de tamaño y por cambiar sus botones en relieve por puntos rehundidos (Gómez Moreno 1919: 88-9, lám. 35. García de Castro: 251-2, nº 179 $\mathrm{y}$ otro fragmento, $\mathrm{n}^{\circ} 183$ ). Una diferencia equivalente ocurre entre sus impostas de aspas con las de Baños (fig. 19; García de Castro: no 392-3).

Evidentemente, estas referencias no nos hacen olvidar el argumento visigotista fundamental, apuntado primero por Jorge Aragoneses y desarrollado por Schlunk (1970: 175-86). Curiosamente las tres piezas toledanas con inscripción y decoradas se pueden relacionar con otras tantas piezas de Baños (fig. 19). La barrotera descubierta en Baños por Palol, con la guarnición del texto principal con el Credo, de Sta. Leocadia, decoradas ambas con una concha y motivos vegetales (Schlunk 1970: lám. 54-5);

${ }^{10}$ Recientemente, durante las obras de restauración de esta iglesia, se ha encontrado un friso trasunto de otro toledano hallado en el Museo de Sta. Cruz, inv. 751, Zamorano: 54, fig. 24. Agradecemos la noticia a Hortensia Larrén Izquierdo. 
VALORES DE LAS UNIDADES DE MEDIDA DE LAS IGLESIAS ALTOMEDIEVALES (* según Lorenzo Arias, 1992)

\begin{tabular}{|c|c|c|c|c|c|c|c|c|c|}
\hline & Romanas & $\begin{array}{c}\text { Santullano } \\
\text { Lillo } *\end{array}$ & Bande & Mata & Nave & Melque & $\begin{array}{l}\text { Naranco * } \\
\text { Valdediós }\end{array}$ & $\begin{array}{l}\text { S. Pedro } \\
\text { Arlanza }\end{array}$ & Baños \\
\hline Decempeda & 295,74 & 294,70 & & & & & & & \\
\hline Passus & 147,87 & & & & & & 167,00 & & \\
\hline Gradus & 73,94 & & & & 81,08 & & & & \\
\hline Cubitus & 44,36 & & & & 48,65 & 49,84 & & $\begin{array}{c}50,13 \\
(49,98)\end{array}$ & 50,77 \\
\hline Palmipes & 36,97 & 37,09 & & 40,49 & & & & & \\
\hline Pes & 29,57 & 30,00 & & & 32,43 & & 33,33 & & \\
\hline Deunx & 27,11 & & 29,67 & & & & & & \\
\hline Semis & 14,79 & & & & 16,22 & & & & \\
\hline \multicolumn{2}{|l|}{$\%$ aumento } & 0,47 & 9,44 & 9,52 & 9,67 & 12,35 & 12,83 & 13,00 & 14,42 \\
\hline
\end{tabular}

la imposta con cintas y botones de la ventana central (como la de El Trampal), con un fragmento quizás de tablero de altar (Zamorano: 34, fig. 6); y el friso con cinta de los ábsides laterales (como los de Tábara), con otro quizás también de tablero de altar (Zamorano: 34, fig. 7).

Pero tampoco vamos a renunciar a la hipótesis contraria, recientemente defendida por uno de nosotros (Caballero 1994-95: 112-6) que cree descubrir la filiación omeya en la decoración de Baños y por lo tanto quizás también en la decoración del Credo de Toledo y en las piezas paralelas con que argumenta Schlunk (1970: 182-6, lám. 56,58-60) su visigotismo: Guarrazar y La Mata (Toledo), La Nave, Quintanilla y Lisboa.

\section{LA MODULACIÓN DEL EDIFICIO}

Hemos de hacer notar, ante todo, que el edificio posee, como suele ser normal, irregularidades en su trazado que impiden una perfecta sincronía entre sus dimensiones reales y el trazado ideal de su modulación. Al trazar la iglesia sobre el terreno se cometió un error que provocó el esviaje de la planta, en forma de romboide con los ángulos NE. y SO. abiertos un grado. Ello hace que, unido a otro defecto en el trazado de la cabecera, los espacios interabsidales acusen diferencias muy notables, de modo que el $\mathrm{S}$. tiene un ancho mínimo de $2,85 \mathrm{~m}$, mientras que el N. llega a los $3,5 \mathrm{~m}$.

La unidad de medida equivale a un codo cercano al medio metro que ya conocemos, con sus variantes, en Melque, Arlanza y La Nave (Caballero y otros, 1991/92: 152-3; Caballero 1995: 387-8). Como se puede ver en el cuadro anejo, la media del valor hallado en Baños es el más alto de todos ellos, equivalente a $50,77 \mathrm{~cm}$, que, salvando el esviaje di- cho, se acomoda bastante bien a las dimensiones en planta y alzado del edificio y nos ayuda a reconstruir la forma primitiva que tuvo ".

La traza modular de la planta de Baños dibuja con facilidad el esquema del cuadrado que Arias denomina «duplicación del cuadrado» ${ }^{12}$ y que $\mathrm{Ku}$ rent (p. 28-9) supone una simplificación del octograma, o esquema del octógono, el dibujo resultante de unir entre sí sus vértices de modo que sus dimensiones son proporcionales a «zeta», ó $1+\sqrt{2}$, y $\sqrt{2}$. El diagrama de Baños (fig. 21) incluye la planta por entero en un cuadrado mayor de 40 codos. El segundo cuadrado (A,B,C,D) de 20 codos dibuja teóricamente el quadratum del aula hasta la salida de las pilastras. El tercero $(m, n, o, p)$ determina el ancho de la nave central. El cuarto equivale a la unidad de uso, 5 us. Así queda definida la serie proporcional $1-\sqrt{2}-2-2 \sqrt{2}-4-\ldots$ principal. Este esquema basta para trazar toda la planta, pero para obtener

"Quizás tenemos una contraprueba de este valor en los datos de Sandoval (Quadrado 1885: 332 n. 2): la nave que cruza entre el cuerpo de la iglesia y los altares tiene noventa quartas (de vara) de largo y trece palmos de ancho. La cuarta y el palmo equivalen a una cuarta parte de la vara, o sea $20,9 / 21 \mathrm{~cm}$. Con este valor, la longitud del seudo crucero sería de $18,81 / 18,9 \mathrm{~m}$ que equivale a la supuesta por modulación (40 us. menos 3 del grueso de muros, $37 \times 50,77=$ $18,78 \mathrm{~m})$. El ancho sería 2,72/2,73 $\mathrm{m}$ que se acerca a la acotada en el plano de Aníbal y Agapito, $2,80 \mathrm{~m}$, pero se aleja de la teórica de la modulación, $3,05 \mathrm{~m}$, y de la que se documenta por los restos aún subsistentes tanto a $\mathrm{N}$. como a $\mathrm{S}$. algo menos de $3,00 \mathrm{~m}$. Las medidas de la placa con la inscripción no coinciden con la unidad encontrada, sino con una perteneciente a la misma familia del codo de aprox. 50 $\mathrm{cm}$, pero en una variante menor. Sus medidas (Navascués 1961: 6) son $98 \times 73 \mathrm{~cm}$ que equivalen a $12 \times 9$ palmos de entre 8,11 a $8,166 \mathrm{~cm}$, valor para el cual el del codo equivale a 48,66 ó $48,99 \mathrm{~cm}$, menor que el supuesto para la iglesia de $50,77 \mathrm{~cm}$.

12 Notas recogidas en una conferencia de Arias dada en Oviedo el 4 de Julio de 1995, en relación con la proporción de Sta. Cristina de Lena y Valdediós. 


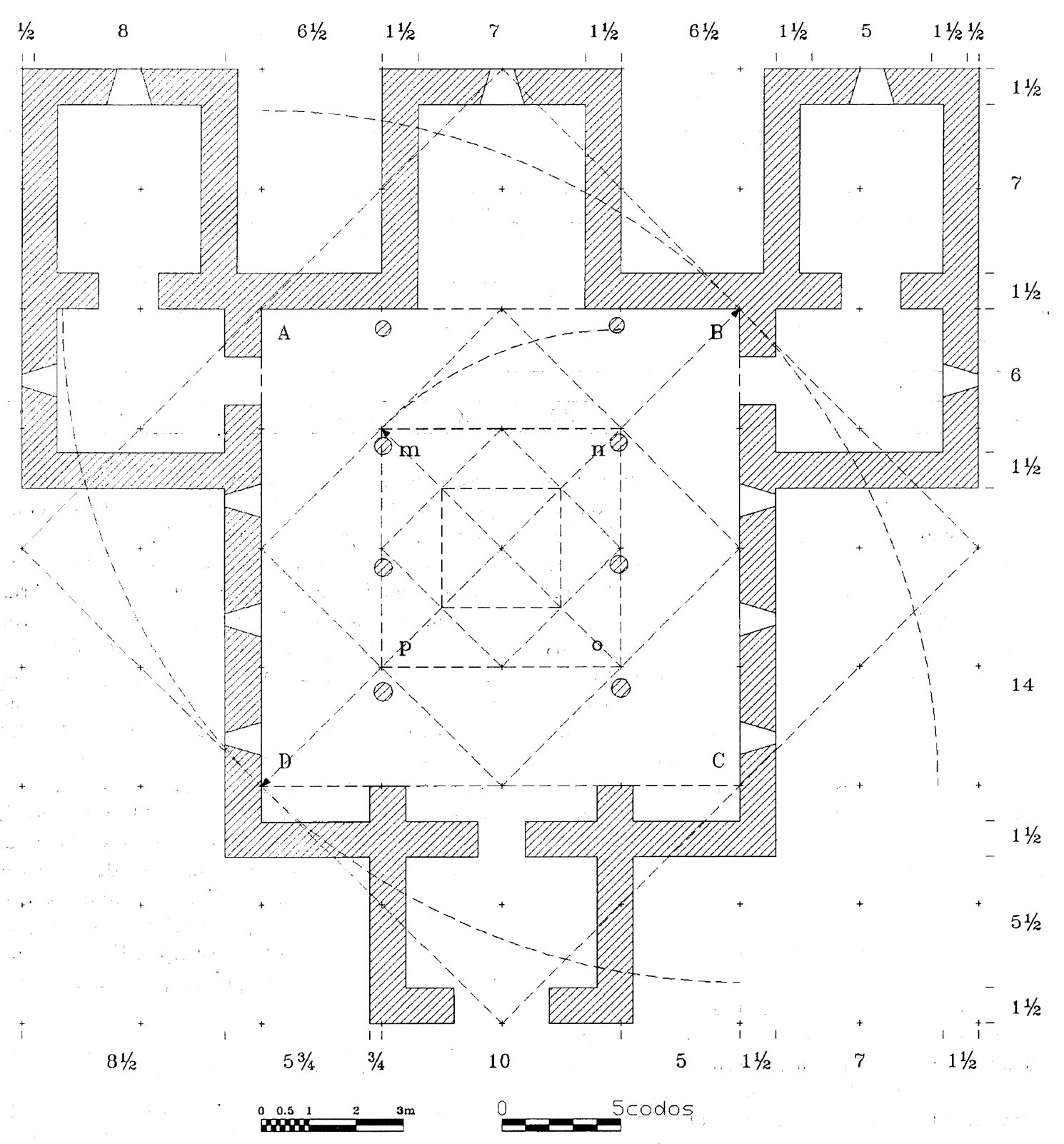

Fig. 21.-S. Juan de Baños. Modulación de la planta. Escala 1/150.

las dimensiones secundarias se pueden utilizar los lados de los cuadrados inscritos o el rectángulo $\sqrt{2}$, obtenido por la diagonal del cuadrado. Las diagonales del cuadrado A,B,C,D trazan el grueso de los muros perimetrales. Corriendo este cuadrado cinco unidades hacia el ábside o hacia los lados, se trazan el testero del aula y los muros proximales de los ábsides laterales. Cuadrados de 15 us. situados en las esquinas de cuadrado A,B,C,D trazan, con media unidad de diferencia, las caras del aula y sitúan los ábsides laterales. La diagonal del cuadrado m,n,o,p señala la posición de las columnas delante del ábside. Con cuadrados de 10 us. ordenados sobre la cuadrícula se trazan el muro $\mathrm{O}$. de los anteábsides y los laterales del pórtico y se sitúan las parejas de columnas. La diagonal del cuadrado de 5 us. vale prácticamente 7 us., medida que se repite por toda la iglesia.

Los alzados se pueden trazar del mismo modo, bastando, lógicamente, sólo medio octograma (fig. 22). O sea, basta con elevar media planta, según uno $\mathrm{u}$ otro eje, para trazar el alzado (igual ocurre en 

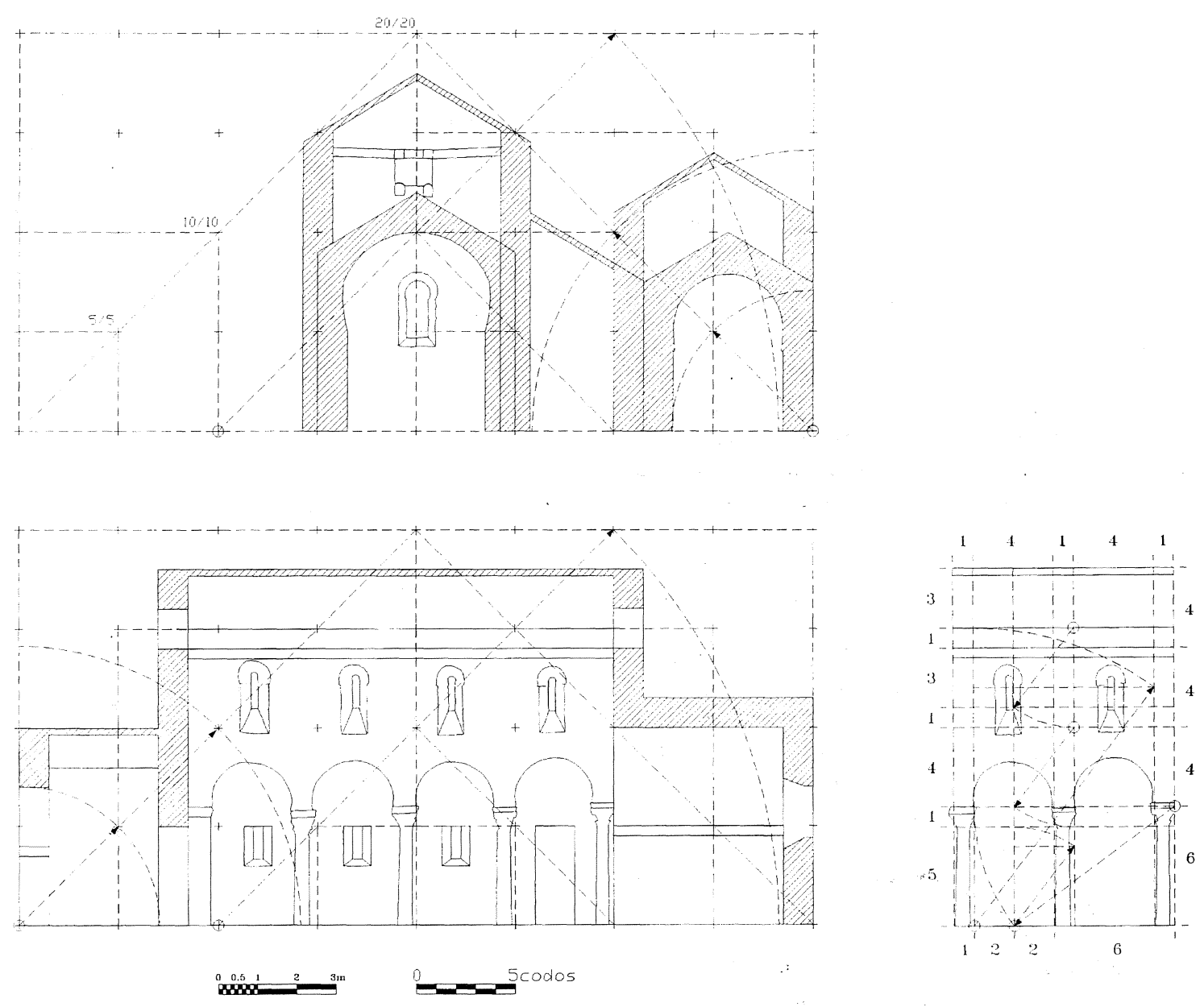

Fig. 22 y 23.-S. Juan de Baños. Esquemas modulares de los alzados de la iglesia y de la arcada. Escala 1/150.

Melque; Caballero y Latorre: 658,669-70). La lima de la cubierta se sitúa dos codos por debajo de la cúspide del semidiagrama, a 18 codos del suelo. La clave del ábside mayor y los umbrales de las ventanas de las arcadas, 10 codos, equivalen a un semicuadrado intermedio. El dintel de la puerta del aula, la altura de los fustes o el asiento de los capiteles y el friso del ábside mayor equivalen a un semicuadrado menor o 5 codos. Tanto con el rectángulo $\sqrt{2}$ como con el 3/4/5 se dibujan las dimensiones secundarias ${ }^{13}$. El trazado de las arcadas (fig. 23) ejemplifica una retícula de trazado muy sencillo que ordena los valores de 1 a 6 , de modo que se pueden elegir las dimensiones apropiadas para trazar cada uno de los elementos en base a cuadrados de 4, 5 ó

13 Arias señaló en la citada conferencia que la «duplicación del cuadrado» no es incompatible con la serie $3 / 4 / 5$, siempre que las medidas elegidas sean conmensurables. Efectivamente, así ocurre en Baños.
6 us. de lado y rectángulos de 3/4/5, 6/8/10 y 9/12/ 15 us. La limitación de espacio nos impide explicitar los detalles de estos trazados.

\section{EL PROBLEMA DEL SUPUESTO CRUCE- RO. PLANTA Y CUBIERTA DE LOS ÁBSI- DES LATERALES Y SUS ANTEÁBSIDES}

Los ábsides laterales fueron menores que el central, como sabemos por el testimonio de Sandoval (Quadrado 1885: 332 n. 2): tiene cinco capillas por frente y la de enmedio es la mayor y las dos últimas colaterales son mas bajas. Este detalle sólo lo recoge el plano de Aníbal (Agapito 1902a: 31) y, con una diferencia apenas apreciable, el de Camps (1946: fig. 249). Posteriormente todos los autores damos los tres ábsides del mismo ancho. La modulación, al incluir la planta de la iglesia en un cuadrado, obliga 
a que los ábsides laterales sean más estrechos que el central. Además, si fueran de igual ancho que el central la planta se desproporcionaría.

El ábside central es además más estrecho que el cuerpo del aula. Exactamente las caras exteriores del ábside se sitúan a eje de los muros de las arcadas y del porche. Este detalle, que hoy es imposible observar directamente en el edificio debido a la fuerte reconstrucción que soporta, sólo lo recoge con exactitud el plano de Cervera (publicado por Palol 1988: 22). Este retranqueo del ábside mayor respecto al aula, o su diferencia de tamaño, es un recurso corriente en nuestra arquitectura altomedieval, por ejemplo se da en los ábsides de La Nave y Quintanilla o en la cabecera y el pórtico de Melque. De este modo se jerarquizan los volúmenes en planta y en alzado. En San Julián de Los Prados (Oviedo), concretamente, la cara exterior del bloque de la cabecera corresponde a la interior del aula (Arias 1993: 48pl.).

Parece lógico que ocurriera lo mismo en los ábsides colaterales. Ello explica que, como ya dijimos, estén desalienados entre sí los muros laterales del aula y los proximales de los ábsides, detalle tampoco observado en ningún plano (aunque Cervera debió estar muy cercano a observarlo según su plano citado). Esta desalineación puede ocurrir de dos modos distintos. La datos de nuestra documentación hacen pensar que, en concreto, la línea de la cara exterior de los muros del aula continuaba en la cara exterior de los muros proximales de los ábsides, ya que la distancia que separa los muros conservados de los ábsides es la misma que existe entre las esquinas occidentales del aula. De esta observación hemos partido para reconstruir la planta de la iglesia, con lo que el interior de los ábsides laterales mide $51 / 2$ us. ó $2,80 \mathrm{~m}$. Pero esta observación entra en contradicción con la cota, $3,00 \mathrm{~m}$, que en el plano de Aníbal mide el ancho interior del ábside N., tras excavar su muro distal (Agapito 1902a: 28). Por otra parte las dimensiones de los ábsides no medirían unidades enteras, 5 1/2 interior y $81 / 2$ exterior. Para solucionar estos dos desajustes habría que mover los muros proximales de los ábsides media unidad hacia el eje del edificio, perdiéndose la observación efectuada sobre los restos conservados y, por lo tanto, la alineación entre las caras externas de los muros de los anteábsides con los del aula, aunque, de este modo, los ábsides laterales tendrían 6 us. interiores $(3,05 \mathrm{~m}$, prácticamente lo medido por Agapito) y 9 exteriores. Ahora bien, la cota de Aníbal puede justificarse, sin necesidad de mover los muros media unidad hacia el eje de la iglesia, si se acepta que la dimensión que midió fue la del fon- do del anteábside, donde la oblicuidad del reconstruido muro lateral del aula daría sin ningún problema esa dimensión que luego él colocaría sobre el plano en una situación más adelantada. En la fig. 21 hemos diferenciado las dos soluciones posibles ${ }^{14}$.

Las dimensiones en alzado de las partes incompletas o desaparecidas son aun más hipotéticas. Pero quizás no son ellas las que importan, sino las formas y soluciones constructivas a que obliga la reconstrucción del edificio. Camps (1946: 516), con su claridad de análisis, advertía que es imposible... suponer una solución que hiciera compatible una armadura para los distintos elementos en ángulo que se acusan en la planta, entre esta nave (de crucero) y las longitudinales. Es muy probable que esta dificultad sea la que haya desanimado a intentar la reconstrucción científica del monumento. Sólo el descubrimiento de El Trampal permitió intuir a Palol (1988: 35) la similitud entre ambos edificios, aunque indicando sus diferencias estructurales, el transepto abovedado y los cimborrios sin vestíbulos. Consecuentemente consideró que Baños tenía un pseudotransepto, un falso transepto (1964: 22). Uno de nosotros (Caballero 1987: 73-5) llegó a una solución parecida, cayendo en la contradicción de aceptar un crucero que no existe... estrictamente, cortado por la nave central e imposible por la cubierta del aula.

El retranqueo señalado en la planta entre los ábsides y sus cuerpos anteriores hace pensar que esta diferencia se acusaría similarmente en el alzado, de modo que los anteábsides laterales significaran volumétricamente pequeñas aulas respecto a sus ábsides. La modulación facilita este planteamiento, pero no soluciona la comprensión constructiva de su cubierta. Ni Camps ni los demás investigadores podíamos resolver este problema mientras partiéramos de la idea de un crucero que atravesaba de parte a parte la iglesia (con la confusa excepción de Puig i Cadafalch: fig. 13) y que obligaba a imaginar una cubierta que cubriera homogéneamente la nave lateral y el tramo de crucero o nave atravesada. La solución creemos que está en la observación de la situación de los huecos para los tirantes de las cubiertas de las naves laterales (fig. 8 y 11). El que sobre las columnas más orientales también existan obliga a continuar los muros laterales del aula hasta su extremo oriental de modo que sobre ellos se puedan apear los tirantes. Por lo tanto a la altura de estas columnas y sus huecos no podía interrumpirse el muro

$14 \mathrm{Al}$ ser los ábsides laterales más estrechos que el central, podría pensarse que, del mismo modo, fueran más cortos, como ocurre en El Trampal. El plano de Aníbal no permite plantear esta posibilidad. 
para abrirse un crucero, como hacen todos los planos de reconstrucción del edificio hasta hoy. El aula tenía que ser un espacio diferenciado de sus alas mediante sendos muros que apeaban, al menos, las cubiertas de las naves laterales. El paso entre el aula y los anteábsides hubo de hacerse a través de vanos abiertos en estos muros. Estos vanos debían ser puertas, del mismo tamaño que la principal del aula, pues es imposible que sobre arcos gemelos de los de la arquería, con sus claves por encima de la línea de los tirantes, apoyaran los pares y su posible durmiente o estribo. Y un arco o dos de tamaño menor (como en el seudo crucero de S. Giâo de Nazaré, Portugal; Schlunk 1971) contrastaría demasiado con los de las arcadas.

Si cada anteábside y su nave lateral son independientes, sus cubiertas también han de serlo. Para conseguirlo, la solución más probable consiste en elevar el cuerpo del anteábside por encima de su propio ábside y de la nave lateral, cubriéndolo a doble vertiente, en correspondencia con el volumen cercano y dominante del aula ${ }^{15}$. Para ello han de recrecerse también, en el tramo correspondiente a cada anteábside, los tramos de los muros del aula comunes con los de los anteábsides, que actúan tanto de muro de carga de la cubierta de la nave lateral como, a mayor altura, de la de cada anteábside. Sin embargo había que solucionar la evacuación de las aguas de lluvia que no podían caer contra los muros recrecidos, pues ello provocaría inexcusablemente humedades y su degradación. La solución obligada consiste en doblar la cubierta de la nave lateral con un cuchillo (formando un falso frontón sobre el lateral del anteábside) que desviara las aguas hacia el frente y los pies (fig. 24a) ${ }^{16}$.

Probablemente la solución que se diera a la cubierta de la nave lateral, fuera o no la propuesta del cuchillo, hubo de crear problemas con el paso del tiempo que se decidió resolver mediante una reforma, elevando toda la cubierta de la nave lateral co-

15 La cubierta también pudo ser a cuatro aguas, como un cimborrio, igual que los de El Trampal y muy probablemente los de La Nave y Quintanilla. Su planta aproximadamente cuadrada podría ser un argumento a su favor, pero también es cuadrada la planta del aula. Aunque nosotros proponemos la doble vertiente, las razones a favor de una u otra solución no son para nosotros definitivas.

16 Otra solución, que el tramo de la nave lateral correspondiente al anteábside se cubriera a doble vertiente, como ocurre en los tramos intermedios del crucero del Trampal (Caballero y otros 1991: fig. 3, lám.), es simplemente imposible pues el esquema del alzado no correspondería al de la planta, elevaría la cubierta por encima de la nave lateral obligando a elevar a su vez la del anteábside, complicaría innecesariamente la armadura, taparía las ventanas orientales de aula y entraría en contradicción con los huecos para los tirantes en las naves laterales. rrespondiente al tramo común del anteábside, continuando los faldones del aula hasta el anteábside, demoliendo para ello la parte alta de éste. De esta reforma quedan en el lado N. los mechinales para las vigas (A 1047, fig. 6). Es probable que este problema de cubiertas fuera el arranque de la reforma gótica que, a la postre terminaría por destruir los dos alas laterales. Hay que tener en cuenta que la reforma gótica no sólo construyó las capillas intermedias, sino que, para ello tuvo que demoler parte de la superestructura de los anteábsides y cortar (sino estaban ya cortados) los tramos comunes de los muros laterales del aula, sustituyéndolos por arcos a los que parece referirse el libro de fábrica en 1588, hasta el rrecibo del arco para de este modo poder abrir la nave que cruza, en expresión de Sandoval. La restauración gótica debió tender, por economía de medios, a simplificar y unificar las cubiertas, un proceso histórico que suele ocurrir en todas las iglesias altomedievales y que es paradigmático en El Trampal, donde sucesivas restauraciones convirtieron las 24 vertientes originales de la cabecera en una sola en forma de gran abanico. En Baños se debieron cubrir las cinco capillas con una vertiente de este tipo que lateralmente llegaba casi hasta el suelo, como parece reflejarse en la documentación histórica (1588 y 1589; como aún la reconstruye Puig i Cadafalch: fig. 14). A este proceso debe achacarse también el que, en época gótica o en una restauración posterior, se cortara el frontón oriental del aula remontando por encima la cubierta de la cabecera, imagen turbadora que aún mantiene (fig. 24b).

\section{OTRAS CUESTIONES ARQUITECTÓNICAS}

Los ábsides laterales, lógicamente, tendrían ventanas parecidas a las del ábside central, decoradas con sus impostas de las que quedan restos (fig. 19). También es lógico que las naves laterales del aula y los muros distales de los anteábsides tuvieran ventanas como las que existen en el aula de La Nave. Y que pertenezca al frontón oriental del aula la pieza que consideramos ajimez, semejante a la del testero, como ya hemos dicho. Las ventanas altas del aula (que Camps: 523 n. 19 paraleliza con las de las arcadas de la mezquita de Damasco) unifican dos modelos distintos, por fuera son monolíticas y por dentro adoveladas, único ejemplo a lo que sabemos en nuestra arquitectura altomedieval. Su imagen exterior responde al tipo monolítico estudiado por Barroca que considera postvisigodo, aunque lamentablemente no trató este modelo, pues hubiera sido de interés saber su opinión, si lo admitía como prece- 

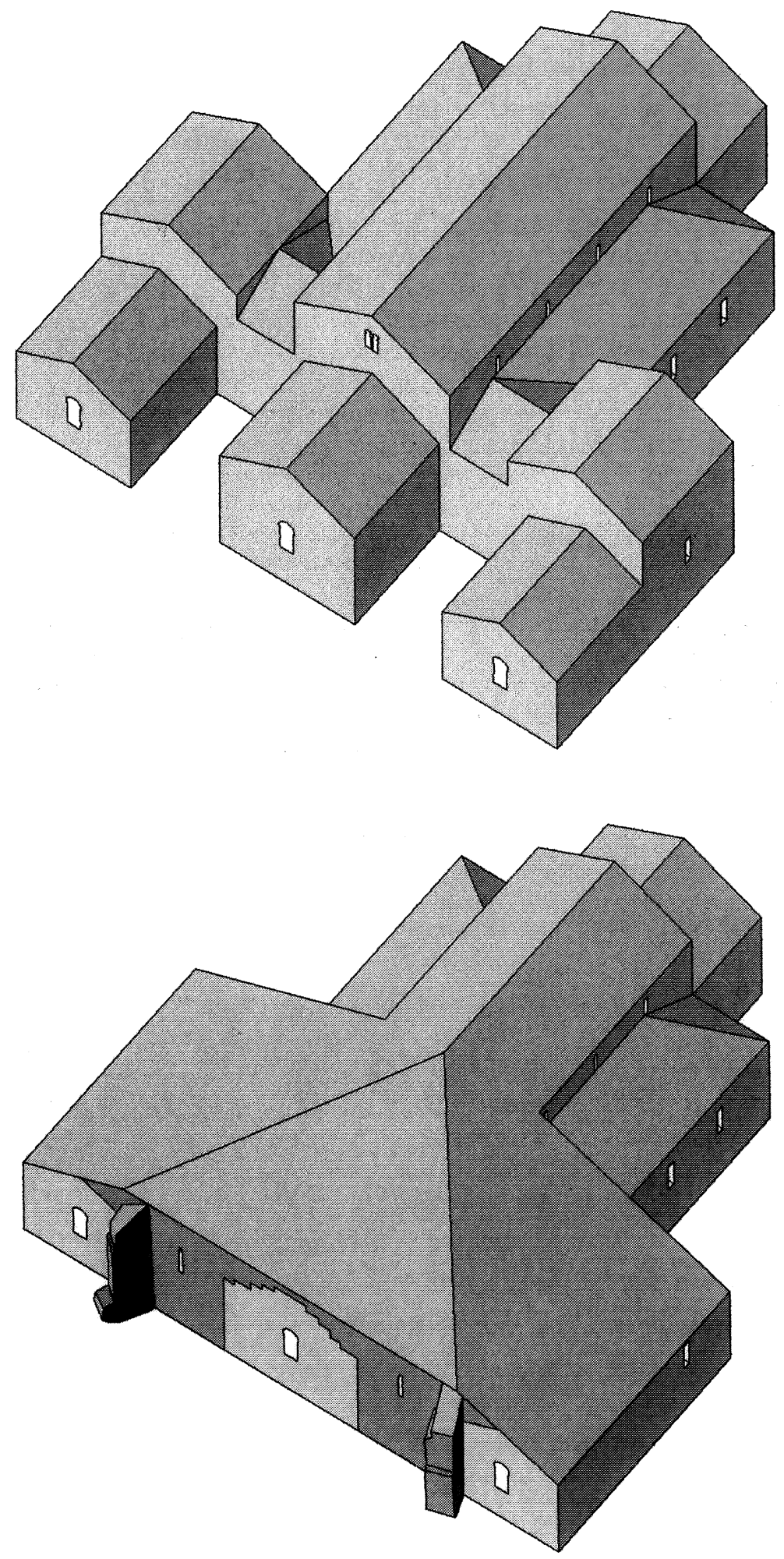

Fig. 24.-S. Juan de Baños. Perspectiva de su reconstrucción en su momento original y tras la refacción gótica. dente de su tipo (de aceptar que la iglesia es de la época visigoda que data la inscripción) o como coetáneo. La complicación del tipo, suma de dos distintos, podría significar que es posterior a la aparición de ambos y por lo tanto de un momento, tipológicamente hablando, de evolución (fig. 8-11).

La iglesia de Baños ofrece otras singularidades. Una, que sus ábsides laterales sean habitaciones cerradas por puertas. A partir de los datos que se conocen de la jamba de la puerta del ábside S. y de las dos variantes que hemos barajado para las plantas de estos ábsides, sus puertas podían ser de $11 / 2$ us. de ancho, si el del ábside fuera de 5 $1 / 2$ us., o de 2 us. en el caso de que el ancho interior de los ábsides fuera de 6 us., dejando, en los dos casos, muros hasta las esquinas de una unidad. Suponemos que su altura no sobrepasaría las 4 us., en una proporción tan esbelta que, muy probablemente, estarían adinteladas y no arcuadas. Son una excepción. A lo que nosotros recordamos no existen puertas en los ábsides laterales de las iglesias españolas. A no ser que su función fuera la misma que tuvieran las habitaciones laterales de La Nave y Quintanilla, a las que se accedía por puertas, o las de las asturianas Santullano y S. Salvador de Valdediós (Arias 1993: 48y218, pl. ) o las traseras de Sta. María de Lebeña (Cantabria. Gómez Moreno 1919: 272-3). También pueden ser paralelos la puerta en el extremo NE. de Nazaré, dé paso a un ábside o a una habitación lateral, y, entre las paleocristianas, por ejemplo y no sin problemas, los ábsides laterales con puertas de Casa Herrera (Mérida. Caballero y Ulbert: pl. reconstrucción).

También se ha discutido en 


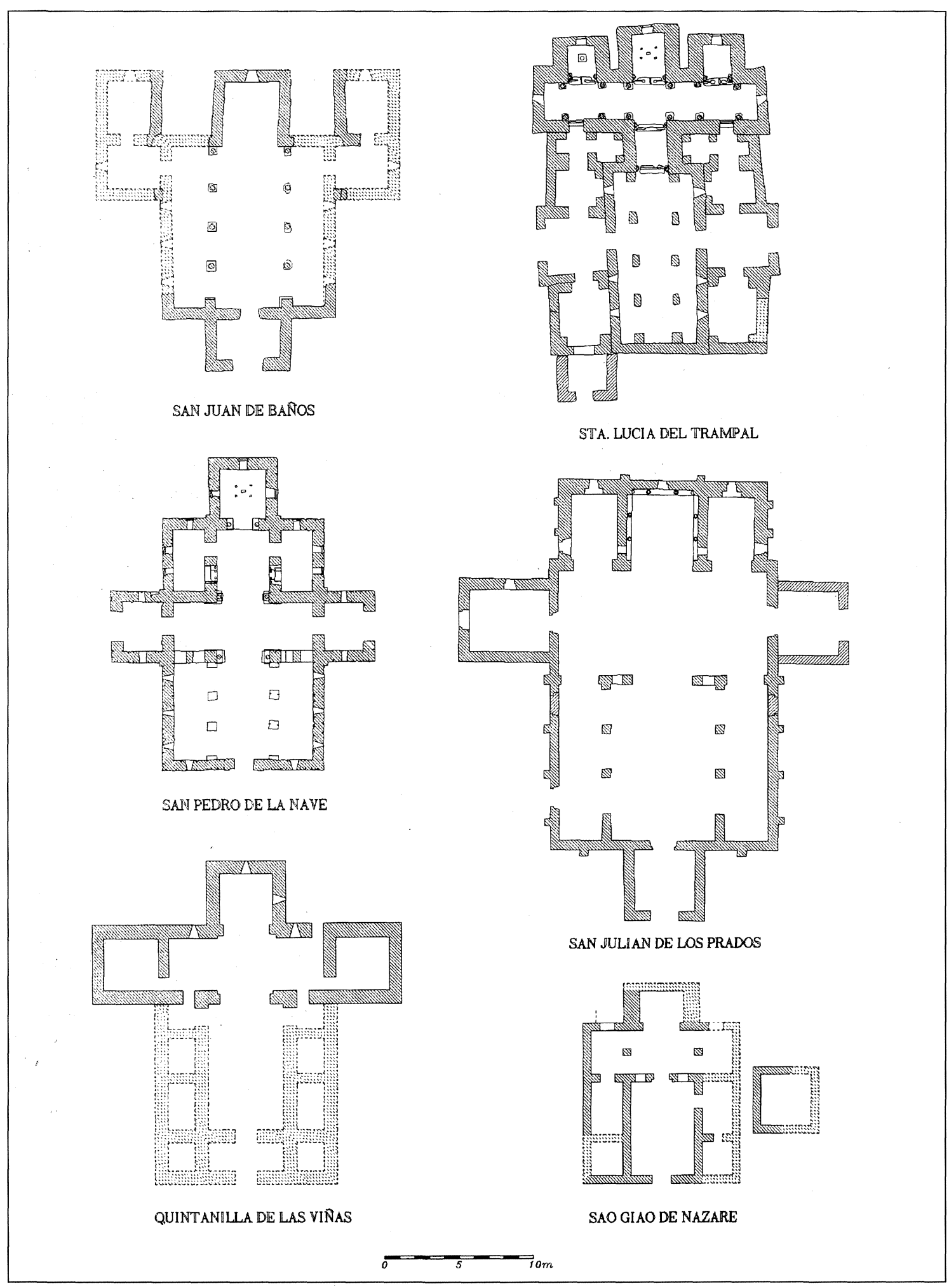

Fig. 25.-Planos de las principales iglesias citadas en el texto. Baños, El Trampal, La Nave, Santullano, Quintanilla, Nazaré. Escala $1 / 400$. 
Baños la existencia de puertas en los anteábsides hacia el exterior o el O. Para Aníbal y Agapito existían allí puertas, de las que Palol (1964: 4-6) no descubre evidencias y por ello cree que no existieron. Nosotros no somos capaces de terciar en esta polémica en que se enfrentan dos testimonios de primera mano, aunque en la fotografía de la excavación de Palol tal muro del anteábside N. parece rematar en la jamba de una puerta (Palol 1964: lám. IV, 5 , no documentado en planimetría). Por otra parte puertas en situación formal parecida existen en otras iglesias. Por ejemplo, en El Trampal al O. del crucero y enfrentadas a los ábsides laterales, o en $\mathrm{Na}$ zaré en las habitaciones de esquina NE. y SE. Evidentemente todas ellas presentan diferencias con Baños que impiden tomar una decisión adecuada. En cualquier caso, su discusión no debe separarse de la posible existencia de otros espacios exteriores. El plano tradicional de Aníbal presenta una columnata cerrando el cuadrado exterior de la planta (fig. 1,3). Es evidente que la planta de Baños, tal como hoy la conocemos, pide completarse arquitectónicamente con un volumen en sus esquinas occidentales. Pero ningún hallazgo avala ese cierre. Los mismos Agapito y Revilla, a pesar de dibujar el pórtico ideal basándose en el testimonio de Ponz (280-1), a los pies de la puerta principal... se conserva un pórtico con columnas bastante arruinado, no estaban de acuerdo sobre su existencia. Aníbal lo creía de fundamento serio, mientras que para Agapito el testimonio de Quadrado (1885: $332 \mathrm{n}$. 1), un atrio de ocho pies hoy casi derruido avalaba su existencia, aunque, al conocer la documentación moderna, terminó desdiciéndose al creer que lo que vio Quadrado tenía que ser el cierre del cementerio moderno (Agapito 1902a: 28-29, planta p. 31; Id. 1903-4: 158-9). Gómez Moreno (1966: 123) aceptó la solución de compromiso de un soportal seguramente moderno. Aún se ha utilizado esta imagen para defender la relación paleocristiana de Baños con la iglesia de S. Sergio de Rusafa en Siria (Corboz: $77-$ 8). Tan ideal como esta propuesta del pórtico sería la de defender habitaciones laterales basándose en la semejanza que Baños posee con la iglesia de El Trampal o la presencia de estas habitaciones en Nazaré, Quintanilla y La Mata (fig. 25. Caballero y Arce 1997: 261, fig. 17).

Su estructura basilical, cubierta de madera, parece alejada del grupo de iglesias consideradas visigodas si, como parece, las de La Nave y Quintanilla estuvieron abovedadas (Caballero y Arce 1997: 264, fig. 18-9). En este sentido queda intermedia entre las referencias de El Trampal, si se cubrió con madera, y Santullano. También es una excepción, sin paralelos, el uso de columnas, probablemente en un intento de recuperar elementos de abolengo. En cambio, el remate de las arcadas en pilastras es un elemento típico de la arquitectura altomedieval, presente, por ejemplo, en mezquitas omeyas (no sólo en monumentos como la Gran Mezquita de Damasco, sino en pequeñas como Qusayr al-Hallabat, Jordania, de tres naves abovedadas sobre arquerías; Creswell: 140) y en iglesias hispánicas como La Nave (Caballero y Arce 1997: 260), El Trampal, Santullano y Valdediós.

\section{CONCLUSIONES}

A pesar de la importancia que se le otorga, a la iglesia de Baños le faltaba un análisis detallado que pretendiera resolver sus problemas. Tras su documentación y análisis arqueológico hemos intentado una reconstrucción de su planta, alzado y cubiertas, aunque sobre los elementos perdidos siempre tendremos la duda de su verdadera forma, y una explicación del problema que plantea su decoración. Ambas son explicaciones revisables en el futuro, aunque lamentablemente no creemos que una excavación arqueológica permita aclarar alguno de los puntos dudosos, especialmente los de sus ábsides laterales. Excavada esta zona en dos o tres ocasiones distintas, lo más probable es que hoy no se encuentre allí ningún dato de interés. A pesar de ello, si en alguna ocasión se vuelve a intervenir en $\mathrm{Ba}$ ños, aún deberá buscarse arqueológicamente cualquier indicio, y con la mayor meticulosidad posible todavía en sus muros.

El análisis arqueológico del edificio permite afirmar que los restos primitivos llegados a nosotros avalan su unidad constructiva, sin que se deba aceptar que tuviera una ampliación inmediata a su construcción. Tanto el aparejo con que están construidas todas sus partes como la modulación certifican esta unidad y desaconsejan la idea, para la que no existe ningún dato objetivo, de que el edificio fuera el resultado de una o dos sucesivas ampliaciones. Ábsides laterales, con sus recintos delanteros, y arcadas deben considerarse coetáneas entre sí y con los demás elementos de la iglesia, aula, ábside central y pórtico.

La iglesia primitiva no tuvo crucero, de modo que el aula se independiza formalmente de los cuerpos laterales. Fue la restauración gótica la que dio lugar a la aparición del pseudocrucero al transformar de modo radical la cabecera de la iglesia. Esta comprensión previa es necesaria para entender cómo fue la cubierta del edificio, cuyos cuerpos la- 
terales reproducían a escala menor la forma del cuerpo central.

Frente a la unidad constructiva del edificio, en la decoración existen varios grupos. Las impostas de las columnas orientales (grupo 1) y el friso grande de círculos secantes (grupo 2), es seguro que fueron reutilizados de otro edificio, como lo fueron también fustes y capiteles. No se puede asegurar lo mismo de los demás frisos y arquivoltas, aunque es muy probable que también estén reutilizados, parcial o totalmente. Ello no obsta para que en el edificio exista una decoración específicamente realizada para él, como de por sí demuestra el retalle de los frisos reutilizados de círculos. Nada impide que a este tercer grupo, realizado a propósito para el edificio, pertenezca el resto de la decoración, las impostas de las ventanas de los ábsides, las piezas que sujetan la inscripción, los dos ajimeces y las piezas de cancel.

Baños fue un edificio construido con expolios. En todos los elementos del edificio primitivo hay indicios de su procedencia como expolio. Algunos sillares y las dovelas del arco de triunfo presentan huellas de haberse reutilizado y retallado, como ya dijimos. También se reutilizaron las columnas con sus cimacios. Y las piezas del primer grupo decorativo; los frisos de círculos del segundo, que luego se retallaron; y, al menos, una placa de cancel del grupo tercero, tallado en una lápida romana de la que resta en su trasera una hedera y una letra (fig. 19).

No ha sido intención prioritaria nuestra conseguir una fecha nueva para la construcción del edificio. La explicación de carácter cronológico que surge de la ordenación escultórica relativiza la explicación tradicional, contraponiendo a ella otra tan o más plausible. Efectivamente, la inscripción de Recesvinto no se puede asegurar que sea sincrónica del edificio mismo, sino que puede serlo del grupo decorativo reutilizado más primitivo. A la vez el resto de la decoración, incluso los frisos de círculos secantes, pudieron ser realizados en talleres donde ya estaba presente la influencia islámica y la de otros talleres como los asturianos más avanza- dos. Pero, aunque para nosotros esta explicación sea más aceptable, comprendemos que no es más que otra explicación, no una tesis confirmada. La existencia de distintos grupos decorativos no debe utilizarse mecánicamente para argumentar, ni contra la unidad del edificio, ni para datar la iglesia en uno u otro sentido. Su ubicación cronológica y cultural sólo se obtendrá a la par que se consiga un sistema de argumentos referentes al mayor número posible de los caracteres generales de los edificios altomedievales entre los que se incluye, y cuando se obtengan datos contrastados de cronología absoluta.

Sin embargo, si se acepta que la inscripción está reutilizada, se abre una explicación insospechada para este edificio y para la intención que pudo tener quien lo erigiese. Como los Grabar explican, los príncipes altomedievales se adoptaron imaginados linajes de los más ilustres monarcas del pasado. Así lo hicieron, de modo diverso, príncipes sasánidas, omeyas, bizantinos, armenios y georgianos y carolingios entre los siglos VIII y XI (Grabar 1954: 185-7; id. 1965: 869-70 y 875-7; id. 1981: 62-3; Almagro y otros: 57 n. 10). Y, como es bien sabido, el asturiano Alfonso II, intencionadamente y para prestigiar su montanero reinecillo renovó el orden gótico (Sánchez-Albornoz: 362). Quizás la inscripción de Baños sea una expresión más de este afán por manifestar una gloriosa progenie.

Creemos que Baños ha ganado en importancia, aún más si cabe, dentro del panorama de nuestra tarda Antigüedad y alta Edad Media. De cualquier modo, este estudio sobre Baños sólo quiere ser un acicate para avanzar en el conocimiento de lo mucho que aún queda por saber de ella. Pendiente de que se resuelvan las contradicciones que existen sobre su decoración y su datación y, por lo tanto, de que se consiga su adecuada adscripción cultural y así el conocimiento más exacto de su uso social y cultual. Pendiente, no con menor importancia, de recuperar la dignidad de la que hoy carece dado su lamentable estado de conservación y, en lo que sea posible, al menos parte de su antiguo aspecto perdido, del que hoy está tan alejada.

\section{ANEXo 1}

\section{DATOS DOCUMENTALES}

(Con las excepciones citadas, lo demás según Agapito 1902a: 8-14 para los anteriores al s. xvı y Agapito 1903-4: 157-163 para los posteriores)

- Inscripciones árabes. Citadas por Ponz (p. 279-81) en las paredes y en la espadaña a los pies de la puerta principal. Recogida por De La Rada (1872: 568-9), cerca del punto en que arranca el intradós del arco de ingreso al atrio, borrada con crucecitas, que Eduardo Saavedra lee como Baxir ibn C..., mi confianza en Dios y que supone el Baxr o Baxir Ben Catten de tiempos de Al- haken II, quizás guerrero de Almanzor, citado por Almakari. Quadrado (1885: 332 n. y 334 n. ) no la observa ya y critica su explicación.

- 21. 01. 1077, cesión de Alfonso VI al obispo de Burgos de S. Pedro del Campo a cambio de las antiquísimas ermitas del valle de Cerrato, próximas y tal vez unidas a S. Juan de Baños, de Santiago, Sts. Pedro y Pablo y S. Mar- 
tín, bajo la condición de cederlas a los monjes de Cluny, según el P. Serrano. Íñiguez: 53-4.

- 05. 02. 1079, donación de Monio Telliz al monasterio de Sahagún y su abad Julián de los bienes en Bannos, Índice de los documentos del monasterio de Sahagún.

- 1105 , señorío de Baños y la iglesia de S. Juan, patrimonio de $\mathrm{D}^{\mathrm{a}}$ Urraca que cede al presbítero Negro quien, a su vez, los dona al monasterio cluniacense de S. Isidoro de Dueñas.

- 1117, incorporado al monasterio de S. Isidoro de Dueñas por $\mathrm{D}^{\mathrm{a}}$ Urraca como Monasterium sancti Ioannis de Banios (Gómez Moreno 1966: 123-4).

- 1200, confirmación de la donación de 1105 por Alfonso VIII.

- 1208-1247, el obispo palentino D. Tello (según el P. Yepes) consigue por litigio la jurisdicción eclesiástica, no sin que los monjes se reservaran el derecho de visita.

- 1390, Baños, merindad de Cerrato, realengo, con derechos también a S. Isidoro y al castillo de Tariego, Becerro de las Behetrías de Castilla, Pedro I.

- 03. 04. 1427, Pedro Manrique IV adquiere el señorio de Baños tras pleito con los trapenses entregándolo como arras a su esposa Leonor de Castilla, luego perdido por su hijo Fadrique contra Juan II y restituido por Enrique IV (Rollán 1970: 13).

- Fines del s. XV y 1500, sendos pleitos en los que S. Isidoro recobra derechos de la granja de Sta. Coloma aneja a S. Juan y los vecinos otros de heredades en Baños.

- Siglo xVI, a pesar de la reserva de visita ejercida por el monasterio de S. Isidoro en el s. XIII, en este siglo la visita la ejercía la diócesis.

- 1559 a 1610, un libro de visita, y 1559 a 1707, tres libros de cuentas en la parroquia de S. Martín de Baños.

- 1559, primera cita de la iglesia de S. Martín de Baños unida a la de S. Juan.

- 1563, se cita la iglesia de S. Martín de Baños.

- 1565, se cita la iglesia de S. Juan como unida a la de S. Martín. S. Juan: que la socazen (por socalzen?) de por fuera y aderezen en todo lo que fuere necesidad e hagan sacar (construyan?) un lienzo de la parte del cierzo que se haga alto media vara a tres cuartas para que corra el agua afuera e no mojare a la iglesia e por la parte del aire al abrigo frio de la iglesia.

- 1565 a 1610, citada la pila bautismal en S. Juan.

- 1575, S. Juan: un ara quebrada y que se repare la esquina de cantería de la iglesia.

- 1587, S. Juan: que se allane el suelo de la capilla mayor y que se aderece la torre de manera que se pueda subir a tañer con facilidad.

- 1588, S. Juan: que se zierren las dos capillas colaterales que exceden de las tres nabes de suerte que la de la parte de la Epistola se pueda servir de sacristia y la otra pa tener cosas dejando puertas pa entrar y salir y que se cierren desde el suelo hasta el rrecibo del arco como un tabique de yeso; que se tapen las ventanas con alambre para que no entren los pájaros; que al fin de la nave del Evangelio, cerca de la capilla mayor, se quiten las tablas que salen al tejado y se haga un tabique de yeso sobre una buena madera que lo pueda sustentar; que de la parte de afuera tras de la capilla cierren una quiebra y levanten un pedazo de pared tras de la capilla de S. Andrés para que no suban los muchachos.

- 1589, S. Juan: las dos capillas que se mandaron çerrar que no se cierren; que se cierren las ventanas con alambre; que las paredes de la iglesia por dentro que tiene levantado el yeso y descubierta toda la cantería se rehinchan y enluzcan; que se aderece un tabique que está roto a la parte del en ángulo y se rehincha una pared frontera a dicho tabique; que por la parte de fuera donde las paredes tienen falta y se desencajan los sillares, se rehinchen con cal y piedra; que se cierre un agujero sobre la puerta principal; y que la pared de la mano izquierda por la parte de septentrión que está muy baja de modo que desde el suelo pueden subir los muchachos al tejado, que se baje la tierra de modo que quede la pared alta de dos estados.

- 1597, Parroquia de S. Martín: que se agrande. S. Juan: que se socave la capilla mayor y las otras capillas por fuera.

- 1610, S. Juan: dio 24 carros de piedra para el cimiento de las casas de las tercias que se hicieron ese año.

- 1581, 1605, 1612, 1614, 1619, 1639, S. Juan: retejos.

- Mediados del s. XVII, se derriban tapias en S. Martín.

- 1672-1702, S. Juan: A juicio de Agapito en este tiempo se derribarían las capillas colaterales y crucero.

- 1672, S. Juan: se inicia una colecta para su reparación.

- 1699, S. Juan: obras, lucir y componer la ermita, en la parte de las dos colaterales que se habían abierto y amenazaba ruina y fortaleza; y una tapia que estaba malparada.

- Siglo XVIII, se reconoce al citado monasterio derecho a percibir 100 mrs. y se dice que la iglesia o la pila bautismal de S. Juan son propiedad del monasterio.

- 1702, a la vez que se construye la torre de S. Martín, ayuda para sacar la piedra y tierra y demoler algunos paredones de la ermita de S. Juan con los maestros que hicieron la torre de la parroquia.

- 1908, según recoge Simón y Nieto de la tradición popular, las tropas francesas del conde de La Salle fragmentaron la estatua del Bautista en tres partes, siendo restaurada a comienzos de este siglo (Rollán 1970: 57).

ANexo 2

LISTA DE ACTIVIDADES

\begin{tabular}{|c|c|c|c|c|c|}
\hline ACTIV. & NOMBRE & ANTERIOR A & POSTERIOR A & PERÍODO & PLANO \\
\hline 1001 & Posibles huellas de gafa dovelas arco triunfo & 1002 & & I & 12 \\
\hline 1002 & Ábside central obra original & $\begin{array}{l}10071009101110211024 \\
1026 / 3610661068 / 711073\end{array}$ & 1001 & II & $16 / 911 / 2$ \\
\hline 1003 & Ábsides laterales obra original & $\begin{array}{l}1007100910111015 \quad 1017 / 8 \\
102010251067 / 8 \quad 1070 / 1 \quad 1073\end{array}$ & & II & 1245910 \\
\hline 1004 & Arquivoltas y muro arco triunfal obra original & 1005103510371068 & 1002 & II & 7812 \\
\hline 1005 & Muros del aula obra original & $\begin{array}{l}100610081010 / 1 \quad 1015 / 7 \quad 1022 / 3 \\
10371039 / 65 \quad 1068 \quad 1071 \quad 1073\end{array}$ & 10021004 & II & $2 / 1013 / 5$ \\
\hline 1050 & Mechinales extremos dintel puerta principal & 1071 & & II & $13 / 4$ \\
\hline 1006 & Refacción muro $\mathrm{N}$ aula ext. & 101710231071 & 1005 & II/III & 4 \\
\hline 1008 & Refacción muro $\mathrm{N}$ aula ext. & 101510171023 & 1005 & II/III & 4 \\
\hline 1010 & Reparación en jambas puerta entrada & 101110711073 & 1005 & II/IV & $13 / 4$ \\
\hline 1007 & Muros de cierre de espacios interabsidales & 10091011106610711073 & $1002 / 3$ & III & 111 \\
\hline
\end{tabular}




\begin{tabular}{|c|c|c|c|c|c|}
\hline ACTIV. & NOMBRE & ANTERIOR A & POSTERIOR A & PERÍODO & PLANO \\
\hline 1023 & Primera refacción muro $\mathrm{N}$ aula & 101510171071 & $1005 / 61008$ & III & 45 \\
\hline 1047 & Huecos cubierta muro $\mathrm{N}$ nave central ext. & 1071 & 1005 & II/VIII & 4 \\
\hline 1009 & Rotura del muro primitivo de ábsides $\mathrm{N}$ y S & 10111071 & 10031007 & III/IV & 511 \\
\hline 1011 & Reforma ábsides, contrafuertes y puerta principal & $\begin{array}{l}10091012 / 101510171066 / 9 \\
10711073\end{array}$ & $1002 / 3100510071010$ & IV & $124 / 69 / 14$ \\
\hline 1012 & Primer enlucido crucero $\mathrm{N}$ & 1013101510171073 & 1011 & $\mathrm{IV} / \mathrm{V}$ & 5 \\
\hline 1013 & Segundo enlucido crucero $\mathrm{N}$ & $1014 / 510171073$ & $1011 / 2$ & $\mathrm{IV} / \mathrm{V}$ & 510 \\
\hline 1014 & Tercer enlucido crucero $\mathrm{N}$ & 101510171073 & 1013 & $\mathrm{IV} / \mathrm{V}$ & 510 \\
\hline 1015 & Cierre del crucero a $\mathrm{N}$ y $\mathrm{S}$ & 101710711073 & $10031005100810111013 / 41023$ & V & $24 / 510$ \\
\hline 1016 & Refacción enjuta S. fachada porche & 10171071 & 1005 & II/VI & 3 \\
\hline 1017 & $2^{a}$ refacción muros $\mathrm{N}$ y $\mathrm{S}$ aula y porche & 1019106810711073 & $10031005 / 610081011 / 61023$ & VI & $2 / 101315$ \\
\hline 1018 & Corte muro E zona $S$ crucero ext. & 1019106810701071 & 1003 & II/VII & 212 \\
\hline 1019 & $3^{\mathrm{a}}$ refacción muro $\mathrm{S}$ aula ext. & 10681071 & $1017 / 8$ & VII & 78 \\
\hline 1020 & Cajeado en jamba $\mathrm{N}$ ingreso ábside $\mathrm{S}$ ext. & 1070 & 1003 & $\Rightarrow$ II/VIII & 314 \\
\hline 1021 & Cajas de cancel entrada a ábside central & 10711073 & 1002 & $\Rightarrow$ II/VIII & 78 \\
\hline 1022 & Zunchado tímpano 0 nave central ext. & 104910681071 & 1005 & $\Rightarrow$ II/VIII & 314 \\
\hline 1037 & Huecos en arcadas nave central extremo $\mathrm{E}$ & 1071 & 10041005 & $\Rightarrow$ II/VIII & 78 \\
\hline 1043 & Huecos trabe nave central extremo $\mathrm{E}$ & 1071 & 1005 & $\Rightarrow$ II/VIII & 78 \\
\hline 1024 & Agujeros ventana ábside central ext. & 1071 & 1002 & II/VIII & 1 \\
\hline 1025 & Cortes de bóvedas ábsides S y N ext. & 1071 & 1003 & II/VIII & 2411 \\
\hline 1026 & Hueco bajo ventana ábside central ext. & 10691071 & 1002 & II/VIII & 1 \\
\hline 1027 & Grieta en eje ábside central & $1070 / 1$ & 1002 & II/VIII & 11 \\
\hline 1028 & Pareja en huecos en testero ábside central & 1071 & 1002 & II/VIII & 11 \\
\hline 1029 & Varios huecos en testero ábside central int. & 1071 & 1002 & II/VIII & 7811 \\
\hline 1030 & Huecos retablo muros N y S ábside central & 1071 & 1002 & II/VIII & 78 \\
\hline 1031 & Huecos cierre jambas ábside central & 1071 & 1002 & II/VIII & 78 \\
\hline 1032 & Huecos en muros ábside cenrtal int. & 10711073 & 1002 & II/VIII & 7811 \\
\hline 1033 & Pintura en bóveda de ábside central & & 1002 & II/VIII & 7 \\
\hline 1035 & Grietas testero arco triunfal & 10681071 & 10021004 & II/VIII & 12 \\
\hline 1036 & Aguiero teja jambas ábside central & 1071 & 1002 & II/VIII & 78 \\
\hline 1038 & Huecos en arranque arquivolta arco porche ext. & 1071 & 1005 & II/VIII & 3 \\
\hline 1040 & Hueco nave $\mathrm{N}$ lado $\mathrm{S}$ arquería interior & 1071 & 1005 & II/VIII & 6 \\
\hline 1041 & Huecos muros nave central extremo E & 1071 & 1005 & II/VIII & 78 \\
\hline 1042 & Huecos salmeres $4^{\text {a }}$ columna y pilastra nave central & 11071 & 1005 & II/VIII & 7813 \\
\hline 1044 & Hueco $l^{\text {er }}$ capitel arcada $S$ nave central & & 1005 & II/VIII & 8 \\
\hline 1045 & Retalle extremo $\mathrm{E}$ arcada nave $\mathrm{N}$ & & 1005 & II/VIII & 6 \\
\hline 1046 & Hueco en cimacio $4^{a}$ columna & & 1005 & II/VIII & 6 \\
\hline 1048 & Mechinales y caja muro $\mathrm{N}$ nave central ext. & 10711073 & 1005 & II/VIII & 34 \\
\hline 1049 & Restauración tímpano 0 nave central ext. & 10651068 & 10051022 & II/VIII & 314 \\
\hline 1051 & Pareja de huecos muro E porche & 1071 & 1005 & II/VIII & 14 \\
\hline 1052 & Rozas en muro E porche & 1071 & 1005 & II/VIII & 14 \\
\hline 1053 & Hueco sobre dintel muro E porche & 1071 & 1005 & II/VIII & 14 \\
\hline 1054 & Mechinales cubierta muros arcadas naves $N$ y $S$ & 1071 & 1005 & II/VIII & 69 \\
\hline 1055 & Huecos enjutas arcada nave $S$ & 1071 & 1005 & II/VIII & 9 \\
\hline 1056 & Hueco en fuste $4^{a}$ columna nave $S$ & 1071 & 1005 & II/VIII & 9 \\
\hline 1057 & Huecos posible cubierta muro arcada nave $S$ & 1071 & 1005 & II/VIII & 9 \\
\hline 1058 & Hueco durmiente en muro arcada nave $S$ & 1054106210681071 & 1005 & II/VIII & 912 \\
\hline 1064 & Rozas junto ventanas 0 nave central ext. & $10651070 / 1$ & 10051063 & II/VIII & 24 \\
\hline 1065 & Refacción esquina SO nave central & 106810711073 & $100510491063 / 4$ & II/VIII & $2813 / 4$ \\
\hline 1066 & Corte enjarje muros en testero $\mathrm{E}$ ext. & 10681071 & 100210071011 & IV/VIII & 1 \\
\hline 1067 & Grietas en ábsides & 1071 & $1002 / 310091011$ & IV/VIII & $569 / 11$ \\
\hline 1034 & Retalle cimiento embocadura arco triunfal & & 1002 & $>$ II $=<$ VIII & 12 \\
\hline 1059 & Restauración muro S porche ext. & 1071 & 1005 & $>$ II $=<$ VIII & 2 \\
\hline 1061 & Pila agua bendita testero nave central int. & 1071 & 1005 & $>$ II $=<$ VIII & 13 \\
\hline 1062 & Posibles huecos cubierta arcada nave $S$ & 10681071 & 10051058 & $>$ II $=<$ VIII & 9 \\
\hline 1039 & Restauración extremo E muro $S$ nave central & $1063106510681070 / 11073$ & 1005 & VIIIa & 28 \\
\hline 1060 & Huecos para descarga & & 1005 & VIIIa & 315 \\
\hline 1063 & Restauración muro $S$ nave central & $1064 / 510681070 / 11073$ & 10051039 & VIIIa & 28 \\
\hline 1068 & Restauración $2^{2} / 2 \mathrm{~s}$. XIX & $1071 / 3$ & $\begin{array}{l}1002 / 3100510111017 / 91022 \\
1039104910581062 / 3 \quad 1065 / 6\end{array}$ & VIIIIa & $1 / 1012 / 5$ \\
\hline 1069 & Restauración grieta ábside central & $10111070 / 1$ & 10021026 & $\mathrm{VIII} / \mathrm{b}$ & 1 \\
\hline 1070 & Restauración A. Álvarez & 10711073 & $\begin{array}{l}1002 / 31018102010391048 \\
1063 / 41069\end{array}$ & VIIIb & 12411 \\
\hline 1071 & Restauración A. Arenillas & 1073 & $\begin{array}{l}1002 / 3 \quad 1005 / 7 \quad 1009 / 11 \quad 1015 / 9 \\
1021 / 5 \quad 1027 / 32 \quad 1035 / 7 \quad 1039 / 43 \\
1049 / 59 \quad 1061 / 6 \quad 1068 / 70\end{array}$ & VIIIc & $1 / 1113 / 5$ \\
\hline 1072 & Rotura moldura frente E del aula & & 1068 & $\mathrm{VIIIa/d}$ & 1 \\
\hline 1073 & Últimas actuaciones & & $\begin{array}{l}1002 / 3 \quad 1005100710101011 \\
1012 \quad 1015 \quad 1017 \quad 1021 \quad 10321039 \\
1063 \quad 106510681070 / 1\end{array}$ & VIIId & $1 / 57911 / 4$ \\
\hline
\end{tabular}


Anexo 3

\section{S. JUAN DE BAÑOS. UNIDAD DE MEDIDA}

\begin{tabular}{|c|c|c|c|c|}
\hline \multicolumn{2}{|c|}{ dimensiones elegidas } & $\begin{array}{c}\mathbf{n}^{\mathbf{0}} \text { de unidades } \\
\text { (codos) }\end{array}$ & $\begin{array}{l}\text { medida } \\
\text { (metros) }\end{array}$ & $\begin{array}{c}\text { valor de la } \\
\text { unidad (codo) }\end{array}$ \\
\hline \multicolumn{5}{|l|}{ PLANTA } \\
\hline \multicolumn{5}{|l|}{ Longitudinales } \\
\hline \multirow[t]{4}{*}{ Iglesia: } & total exterior & 40 & 20,19 & 0,505 \\
\hline & total interior & 37 & 18,52 & 0,5 \\
\hline & exterior & 10 & 5,13 & 0,513 \\
\hline & interior & $81 / 2$ & 4,32 & 0,508 \\
\hline \multirow[t]{2}{*}{ Aula: } & interior & $211 / 2$ & 10,84 & 0,504 \\
\hline & pilastra a ábside & 20 & 10,25 & 0,513 \\
\hline \multirow{2}{*}{ Porche: } & exterior & 7 & 3,49 & 0,499 \\
\hline & interior & $51 / 2$ & 2,75 & 0,5 \\
\hline \multicolumn{5}{|l|}{ Transversales } \\
\hline \multicolumn{5}{|c|}{ Ábsides laterales: } \\
\hline & caras interiores & 26 & 13,05 & 0,502 \\
\hline & caras exteriores & 23 & 11,57 & 0,503 \\
\hline \multirow[t]{2}{*}{ Ábside central: } & exterior & 10 & 5,16 & 0,516 \\
\hline & interior & 7 & 3,69 & 0,527 \\
\hline \multirow[t]{2}{*}{ Aula: } & esquinas exterior & 23 & 11,54 & 0,502 \\
\hline & esquina interior & 20 & 10,67 & 0,534 \\
\hline \multirow[t]{2}{*}{ Porche: } & exterior & $111 / 2$ & 5,71 & 0,497 \\
\hline & interior & $81 / 2$ & 4,25 & 0,5 \\
\hline \multicolumn{5}{|c|}{ ALZADOS, al suelo } \\
\hline \multicolumn{5}{|c|}{ Ábsides laterales } \\
\hline & ábside N. , friso & 4 & 2,03 & 0,508 \\
\hline \multirow{3}{*}{ Ábside central: } & ábside S. , friso & 4 & 2,01 & 0,503 \\
\hline & friso & 5 & 2,53 & 0,506 \\
\hline & clave bóveda & 10 & 5,04 & 0,504 \\
\hline \multirow[t]{2}{*}{ Aula: } & imposta & 6 & 3,12 & 0,52 \\
\hline & friso & 14 & 7,07 & 0,505 \\
\hline
\end{tabular}

\section{BIBLIOGRAFÍA}

Agapito y Revilla, J. 1902a: La basílica visigoda de San Juan Bautista en Baños de Cerrato (Palencia). Apuntes crítico-artísticos, Valladolid.

ID. 1902b: La basílica visigoda de San Juan Bautista en Baños de Cerrato (Palencia). Apuntes críticoartísticos IV, Arquitectura y Construcción 98-105.

ID. 1903-1904: La iglesia de San Juan de Baños. Notas sueltas, BolSocCastExc 1 156-164.

Almagro, M.; Caballero, L.; Zozaya, J. y Almagro, A. 1975: Qusayr 'Amra. Residencia y baños omeyas en el desierto de Jordania, Madrid.

Arbeiter, A. 1996: Die Anfänge der Quaderarchitektur im westgotenzeitlichen Hispanien, Innovation in der Spätantike (Basel 1994) Reichert Verlag Wiesbaden 11-44

ID., Karas, U. y PÄffgen, B. 1994: San Juan de Baños. Levantamiento planimétrico mediante técnicas novedosas, RevArq 154 6-11.
Arias PÁramo, L. 1992: Geometría y proporción en la arquitectura prerrománica asturiana: la iglesia de San Julián de Los Prados, XXXIX CCARB 1162.

ID. 1993: Prerrománico Asturiano. El arte de la Monarquía Asturiana, Gijón.

Barroca. M. J. 1990: Contribuiçâo para o estudo dos testemunhos pré-românicos de Entre-Douroe-Minho. 1. Ajimezes, Gelosias e Modilhôes de Rolos, Actas do Congresso Internacional do IX Centenário da Dedicaçâo da Sé de Braga, Braga, 1 101-45.

Barroso Cabrera, R. y Morín de Pablos, J. 1996: Los canecillos de San Juan de Baños. Una iconografía bautismal vinculada a la inscripción de Recesvinto, MM 37 187-204, lám. 33-36.

Becerro de Bengoa, R. 1874: El libro de Palencia, Palencia (edic. 1969), p. 77 y 198-9.

Caballero Zoreda, L. 1987: Hacia una propuesta tipológica de los elementos de la arquitectura de 
culto cristiano de época visigoda. (Nuevas iglesias de El Gatillo y El Trampal), II CAME, Madrid, I 61-98.

ID. 1989: Pervivencia de elementos visigodos en la transición al mundo medieval. Planteamiento del tema, III CAME, Oviedo, I 113-134.

ID. 1991: Sobre Santa Comba de Bande (Orense) y las placas de Saamasas (Lugo), Galicia no tempo-1991. Conferencias/otros estudios: Nuevas visiones en torno a la temática de Galicia no tempo, Xunta de Galicia, 73-114.

ID. 1994-5: Un canal de tránsmisión de lo clásico en la alta Edad Media española. Arquitectura y escultura de influjo omeya en la Península Ibérica entre mediados del siglo VIII e inicios del siglo $\mathrm{X}$, al-Qantara 15-6 321-48 y 107-24.

ID. 1995: Zamora en el tránsito de la Edad Antigua a la Edad Media, siglos V-X, en Delibes, G. , Moreta, S., Gutiérrez, J. I. y Mateos, M. A. (coords. ) Historia de Zamora, Instituto de Estudios Zamoranos, Zamora, I 339-430.

ID. 1997: Observations on Historiography and Change from the sixth to tenth centuries in the North and West of the Iberian Peninsula, en Díaz-Andreu, M. y Keay, S. (edit. ), The Archaeology of Iberia. The Dynamics of Change, Routledge, Londres y Nueva York, 235-264.

ID. , Almagro Gorbea, A. , Madroñero de La Cal, A. y Granda Sanz, A. 1991: La iglesia visigoda de «Santa Lucía del Trampal», Alcuéscar (Cáceres), Extremadura Arqueológica 2 497-523.

ID. y ARCE, F. 1995: El último influjo clásico en la Lusitania extremeña. Pervivencia visigoda e innovación musulmana, en Velázquez, A. , Cerrillo, E. y Mateos, P. (edit. ), Los últimos romanos en Lusitania, Cuadernos emeritenses 10 185-217.

EID., 1997: La iglesia de San Pedro de La Nave (Zamora). Arqueología y arquitectura, AEspA 70 221-274.

Id., Cámara Muñóz, L.; Latorre González-Moro, P. y Matesanz Vera, P. 1991/92: La iglesia prerrománica de S. Pedro el Viejo de Arlanza (Hortigüela, Burgos), Numantia 5 139-165.

ID. y Latorre Macarrón, J. I. 1980: La iglesia y el monasterio visigodo de Santa María de Melque (Toledo). Arqueología y arquitectura. San Pedro de La Mata (Toledo) y Santa Comba de Bande (Orense), EAE 109.

ID. y UlBERT, Th. 1976: La basílica paleocristiana de Casa Herrera en las cercanías de Mérida, EAE 89, Madrid.

Camps Cazorla, E. 1946: El arte hispanovisigodo, Historia de España dirigida por Menéndez Pidal, Madrid, III, 510-525.
ID, 1953: Módulo, proporciones y composición en la arquitectura califal cordobesa, Madrid.

Corboz, A. 1970: Haut Moyen Age, Office du Livre, Friburgo.

Corzo Sánchez, R. 1986: San Pedro de La Nave. Estudio histórico y arqueológico de la iglesia visigoda, Zamora.

Cossio, M. B. 1892: Programa de un curso elemental de historia de la arquitectura en España, Boletín de la Institución Libre de Enseñanza 16 177-181.

Creswell, K. A. C. 1979: Compendio de Arquitectura Paleoislámica (edit. A. Jiménez), Sevilla.

FITA, F. 1895: BolRAcaHist 2694.

ID. 1902: Inscripciones visigóticas y suévicas de Dueñas, Baños de Cerrato, Vairáom, Baños de Bande y San Pedro de Rocas, BolRAcaHist 41 476-511. Baños de Cerrato: 486-495.

García de Castro Valdés, C. 1995: Arqueología cristiana de la alta Edad Media en Asturias, Oviedo.

GIL, J. 1978: Epigraphica III, Cuadernos de Filología Clásica 14 83-120.

Gómez Moreno, M. 1906: Excursión a través del arco de herradura, Cultura Española 3 785-811.

ID. 1919: Iglesias Mozárabes, Centro de Estudios Históricos, Madrid.

ID. 1966: Primicias del Arte Cristiano Español, AEArte 39 101-139.

Grabar, O. 1954: The Painting of the Six Kings at Qusayr Amrah, Ars Orientalis 1 185-7.

ID. 1981: La formación del arte islámico, Madrid.

Grabar, O. y A. 1965: L'essor des Arts inspirés par les cours princières à la fin du premier millénaire: princes musulmans et princes chrétiens, Settimane di Studio del Centro Italiano di Studi sull'Alto Medioevo. L'Occidente e l'Islam nell'Alto Medioevo, Spoleto, $\mathrm{T}^{\circ} 2$ 845-901.

Hauschild, Th. 1972: Westgotische Quaderbauten des 7. Jahrhundets auf der Iberischen Halbinsel, MM 13 270-85, lám. 42-7.

ÍñgueZ AlmeCh, F. 1955: Algunos problemas de las viejas iglesias españolas, Cuadernos de Trabajos de la Escuela Española de Historia y Arqueología en Roma 7 8-100.

Jorge Aragoneses, M. 1957: El primer Credo epigráfico y otros restos coetáneos, descubiertos en Toledo, ArchEspA 30 295-323.

KurEnt, T. 1977/78: Cosmogram of the romanesque basilica at Sticna, Yugoslavia, Ljubljana.

LAmpérez y RomeA, V. 1908: Historia de la Arquitectura Cristiana Española en la Edad Media, Madrid, 145-9.

LeclercQ, H. , 1925: Baños (S. Juan Bautista en), 
en Dictionaire d'archeologie chretiènne et de liturgie de Cabrol y Leclercq, II, Paris.

Monumentos Arquitectónicos de España 1877: vol. V, Madrid, lám 64, dibujada por F. Aznar y grabada por P. Arredondo.

Navascués, J. Ma de. 1961: La Dedicación de San Juan de Baños, Palencia. Con la bibliografía completa sobre el epígrafe, aunque alguna cita errada.

NOACK, S. 1987: En torno al «arte mozárabe», II CAME, Madrid, III, 581-8.

Palol y Salellas, P. de 1964: Excavaciones en la necrópolis de San Juan de Baños (Palencia), con un estudio anatómico de los restos humanos por Fernández Martín, A. y Anitua Solano, M. , EAE 32, Madrid.

ID. 1988: La basílica de San Juan de Baños, Palencia.

ID. 1989: La arqueología cristiana en la Hispania romana y visigoda. Descubrimientos recientes y nuevos puntos de vista, Actes du XIe Congrès Internationale d'Archeologie Chrétienne (1986), Studi di Antichità Cristiana 41 II 1975-2027.

ID. 1991: III. Arte y Arqueología, en Historia de España dirigida por Menéndez Pidal, Madrid, III **, 269-428.

ID. y RipolL, G. 1988: Los godos en el Occidente europeo, ostrogodos y visigodos en los siglos vVIII, Madrid.

ID., Tuset, F. y CoRTES, J. 1983: Excavaciones en la iglesia visigoda de San Juan de Baños, Palencia, 1982, Publicaciones de la Institución «Tello Téllez de Meneses» 49 241-263.

Ponz, A. 1787: Viage de España (2 edic. ) Madrid ( $\mathrm{T}^{\circ} \mathrm{XI}$, carta VI, párrafo 111, 279-281).

Puig i Cadafalch, J. 1961: L'art wisigothique et ses survivences, Paris.

Quadrado, J. Ma 1885: España. Sus monumentos y artes. Valladolid, Palencia, Zamora, (2 $2^{\mathrm{a}}$ edic. ) Barcelona.

Rada y Delgado, J. de D. de la. 1872: Basílica de San Juan Bautista fundada por Recesvinto, que se conserva en la villa de Baños de Cerrato o de río Pisuerga, provincia de Palencia, Museo Español de Antigüedades, Madrid, I (p. 561-571 y lám. ).

ID. 1893: El templo de San Juan Bautista de Baños, en Historia de España desde la invasión de los pueblos germánicos hasta la ruina de la monarquía visigoda, vol. III, Historia General de Es- paña, dirigida por Cánovas del Castillo, Madrid (p. 40 y 43-63).

REAL, M. L. 1995: Inovaçâo e resistência: dados recentes sobre a antiguidade cristâ no ocidente peninsular, IV Reunió d'Arqueologia Cristiana Hispànica (Lisboa 1992), Barcelona, 17-68.

Rivera Blanco, J. 1997: La restauración histórica de la Alta Edad Media, en Hevia Blanco, J. (comp. ), La intervención en la arquitectura prerrománica asturiana, Gijón, 59-70.

Rodríguez, T. y Simón y Nieto, F. 1904: Comunicaciones é informe presentados a este Congreso sobre la basílica visigoda de San Juan Bautista en Baños de Cerrato (II ${ }^{\circ}$ Congreso Internazionale di Archeologia Cristiana, Roma 1900), Palencia 1904, 19 p.

Rollán OrTíz, J-M. 1970: La basílica de Recesvinto. San Juan Bautista en Baños de Cerrato (Palencia), Palencia, 75 p.

SÁncheZ-AlboRnOZ, C. 1980: La España cristiana de los siglos VIII al XI. El reino astur-leonés (722 a 1037), Historia de España fundada por Menéndez Pidal, Madrid, To VII *.

Schlunk, H. 1945: Observaciones en torno al problema de la miniatura visigoda, AEspArte 71 241-265.

ID. 1947: Arte Visigodo. Arte Asturiano, Ars Hispaniae, II, Madrid, 273-280.

ID. 1970: Beiträge zur Kunstgeschichtlichen Stellung Toledos im 7. Jahrhundert, MM 11 161-86, lám. 43-60.

ID. 1971: La iglesia de S. Giâo, cerca de Nazaré. Contribución al estudio de la influencia de la liturgia en la arquitectura de las iglesias prerrománicas de la Península Ibérica, Actas do II Congresso Nacional de Arqueología, Coimbra, 509-528.

ID. y Hauschild, Th. 1978: Die Denkmäler der frühchristlichen und westgotischen Zeit, Hispania Antiqua, Mainz am Rhein.

Velázquez Soriano, I. y Ripoll, G. 1992: Pervivencias del termalismo y el culto a las aguas en época visigoda hispánica, Espacio, Tiempo y Forma $5555-580$.

VIVES, J., 1942: Inscripciones cristianas de la España romana y visigoda, Barcelona.

Williams, J. 1970: A contribution to the History of the Castilian Monastery of Valeranica and the scribe Florentius MM 11 231-248, lám. 70-77.

Zamorano Herrera, I. 1974: Caracteres del arte visigodo en Toledo, Anales Toledanos 10 3-149. 